UNIVERSIDADE DE SÃO PAULO

PROGRAMA INTERUNIDADES DE PÓS-GRADUAÇÃO EM BIOINFORMÁTICA

Construção e Aplicação de HMMs de Perfil para a Detecção e Classificação de Vírus

Miriã Nunes Guimarães

SÃo PAULO

2019 


\section{Construção e Aplicação de HMMs de Perfil para a Detecção e Classificação de Vírus}

\section{Miriã Nunes Guimarães}

Dissertação apresentada à Universidade de São Paulo, como parte das exigências do Programa de Pós-Graduação Interunidades em Bioinformática, para obtenção do título de Mestre em Ciências.

Área de Concentração: Bioinformática

Orientador: Prof. Dr. Arthur Gruber

SÃO PAULO

2019 


\section{FICHA CATALOGRÁFICA}

\begin{tabular}{|l}
\hline Guimarães, Miriã Nunes \\
Construção e aplicação de HMMS de perfil para a deteç̧ão e classificação \\
de vírus. / Miriã Nunes Guimarães, [orient.] Arthur Gruber. São Paulo : 2019. \\
$66 \mathrm{p}$. \\
Dissertação (Mestrado) - Universidade de São Paulo \\
Orientador: Prof. Arthur Gruber \\
Programa Interunidades de Pós-Graduação em Bioinformática \\
Área de concentração: Bioinformática \\
1. Bioinformática. 2. Marcador molecular. 3. Genomas. 4. Virus. 5. Modelos \\
para processos estocásticos. I. Gruber, Arthur, orientador. II. Universidade de São \\
Paulo. III. Título. \\
CDD - 572.8
\end{tabular}

Elaborada pelo Serviço de Informação e Biblioteca Carlos Benjamin de Lyra do IME-USP, pela bibliotecária Maria Lucia Ribeiro CRB-8/2766 
"Na vida, não existe nada a temer, mas a entender." Marie Curie 


\section{Agradecimentos}

Ao Professor Arthur Gruber pela oportunidade desde o início como estagiária no laboratório, pela orientação neste período de aprendizado no mestrado e por fornecer um ambiente de trabalho favorável.

À aluna de doutorado Liliane Santana Oliveira que aguentou todas as minhas amolações diárias no laboratório pelo Hangouts, por dúvidas que eram erros meus em comandos de execução, pela paciência, pela amizade, pela companhia nos bandejões da faculdade com cardápio glutenfree que nem sempre eram tão bons assim.

À aluna de mestrado Irina Yuri Kawashima que estava comigo no laboratório diariamente, pelas várias discussões sobre o mundo dos vírus e de conhecimentos da bioinformática, pelas ferramentas para facilitar o andamento do projeto, por todas guloseimas glutenfree que seria impossível eu não agradecer pois tenho ciência que não vou encontrar outra amiga masterchef assim.

À Coordenação de Aperfeiçoamento de Pessoal de Nível Superior - Brasil (CAPES) pelo financiamento durante estes 24 meses de mestrado.

Aos meus pais pelo carinho e preocupação comigo durante estes 24 anos, pelo incentivo aos estudos e pelo apoio para eu me manter a uma distância de quase $400 \mathrm{~km}$ de pura saudade.

Ao Almir Ferreira que era pós-doc no laboratório pelas várias risadas, clima alto astral, pelo café da salinha dos estudantes, por me aconselhar nos meus dias e por tornar-se quase o meu pai, já que me deixava em casa depois que acabava o expediente do laboratório praticamente todos os dias durante o meu primeiro ano.

Ao Wendel Hime Lino Castro pelo companheirismo durante o período no laboratório, pelas dicas em programação, pela companhia nas marmitas durante o almoço no estágio e pela grande amizade.

Agradeço a todos as pessoas que contribuíram de alguma forma para que este projeto fosse possível. 


\section{Apoio financeiro}

O presente trabalho foi realizado com apoio da Coordenação de Aperfeiçoamento de Pessoal de Nível Superior - Brasil (CAPES) - Código de Financiamento 001 


\section{Resumo}

Guimarães, M.N. Construção e aplicação de HMMs de perfil para a detecção e classificação de vírus. [dissertação (Mestrado em Ciências)] - Programa Interunidades de Pós-Graduação em Bioinformática, Universidade de São Paulo, São Paulo, 2019.

Os vírus são as entidades biológicas mais abundantes encontradas na natureza. O método clássico de estudo dos vírus requerem seu isolamento e propagação in vitro. Contudo, necessita-se ter um conhecimento prévio sobre as condições necessárias para seu cultivo em células, sendo assim a maior parte dos vírus existentes não é conhecida. Análises metagenômicas são uma alternativa para a detecção e caracterização de novos vírus, uma vez que não requerem um cultivo prévio e as amostras podem conter material genético de múltiplos organismos. Uma vez obtidas as sequências montadas a partir das leituras metagenômicas, o método mais utilizado para a identificação e classificação dos organismos é a busca de similaridade com o programa BLAST contra bancos de sequências conhecidas. Contudo, métodos de alinhamento pareado são capazes de identificar apenas sequências com identidade superior a 20-30\%. Uma alternativa a essa limitação é o uso de métodos baseados no uso de perfis, que podem aumentar a sensibilidade de detecção de homólogos filogeneticamente distantes. HMMs de perfil são modelos probabilísticos capazes de representar a diversidade de caracteres em posições-específicas de um alinhamento de múltiplas sequências. Nosso grupo desenvolveu a ferramenta TABAJARA, utilizada neste projeto, para a identificação de blocos que podem ser conservados em todas as sequências do alinhamento ou discriminativos entre grupos de sequências. Esses blocos são utilizados para a geração de HMMs de perfil, os quais podem ser usados, no contexto da virologia, para a identificação de grupos taxonômicos amplos como famílias virais ou, ainda, taxa mais restritos como gêneros ou mesmo espécies de vírus. O presente projeto teve como objetivos aplicar e otimizar o programa TABAJARA em diferentes grupos taxonômicos de vírus, construir modelos específicos para cada um desses grupos e validar esses modelos em dados metagenômicos. O primeiro modelo de estudo escolhido foi a ordem Bunyavirales, composta de vírus de ssRNA (-) majoritariamente envelopados e esféricos, com genoma segmentado e pertencentes ao grupo 5 da classificação de Baltimore. Este grupo inclui vírus causadores de várias doenças em humanos, animais e plantas. O segundo modelo de estudo escolhido foi a família Togaviridae, composta de vírus de ssRNA (+) envelopados e esféricos, cujo genoma expressa uma poliproteína e pertencem ao grupo 4 da classificação de Baltimore. Este grupo inclui o vírus Chikungunya e outras espécies que causam diversas patologias ao homem. O terceiro modelo de estudo escolhido foi a subfamília Spounavirinae, compreendendo bacteriófagos que infectam vários hospedeiros bacterianos e em alguns casos possuem potencial terapêutico comprovado contra infecções bacterianas que afetam o homem. Estes fagos apresentam partículas virais com estrutura cabeça-cauda, não são envelopados, apresentam genoma de dsDNA e pertencem ao grupo 1 da classificação de Baltimore. Todos os modelos construídos foram validados quanto à sensibilidade e especificidade de detecção e, ao final, foram utilizados em análises de prospecção de vírus em dados metagenômicos obtidos na base SRA do NCBI. Os HMMs de perfil apresentaram excelente desempenho, comprovando a viabilidade da metodologia proposta neste projeto. Os resultados apresentados neste trabalho abrem a perspectiva da ampla utilização de HMMs de perfil como ferramentas universais para a detecção e classificação de vírus em dados metagenômicos. 
Palavras-chave: Modelos ocultos de Markov, Detecção de vírus, Metagenômica, Marcadores moleculares, Taxonomia viral, HMMs de perfil. 


\section{Abstract}

Guimarães, M.N. Construction and application of profile HMMs for the specific detection and classification of viruses. [thesis (Master degree in Science)] - Programa Interunidades de Pós-Graduação em Bioinformática, Universidade de São Paulo, São Paulo, 2019.

Viruses are the most widely biological entities found in nature. Most of the information that can be obtained from these organisms requires viral in vitro isolation and cultivation. However, most of the existing viruses are still unknown because the biological requirements for their successful propagation have not been identified so far. Metagenomic analyses offer an interesting alternative for the detection and characterization of novel viruses, since previous cultivation is not required, and the samples may contain genetic material of multiple organisms. Once assembled sequences are obtained from individual reads, the most widely used method for viral identification and classification is the use of BLAST similarity searches against databases of known sequences. However, pairwise alignment methods are only able to identify sequences that present identity greater than 20-30\%. Profile-based methods may increase the sensitivity of detection of remote homologues. Profile HMMs are probabilistic models capable of representing the diversity of amino acid residues at specific positions of a multiple sequence alignment. Our group is developing TABAJARA, a tool for the identification of alignment blocks that are conserved across all sequences of the alignment or discriminative between groups of sequences. These blocks are used to generate profile HMMs, which can in turn be used, in the context of virology, to identify broad taxonomic groups, such as viral families, or narrower taxa as genera or viral species. The present project aimed to apply and standardize the use of TABAJARA in different taxonomic groups of viruses, to build specific models for each of these groups and to validate these models in metagenomic data. We used three viral models for this study. The first chosen model was the Bunyavirales order, composed of mostly enveloped and spherical ssRNA(-) viruses with a segmented genome belonging to group 5 of the Baltimore classification. This group includes viruses that cause several important diseases in humans, animals and plants. The second chosen model was the Togaviridae family, composed of enveloped and spherical ssRNA(+) viruses, with a genome coding for a polyprotein, and belonging to group 4 of the Baltimore classification. This group includes the Chikungunya virus and some other viral species that cause relevant pathologies to humans and animals. Finally, we used the Spounavirinae subfamily, comprising viruses that infect a variety of bacterial hosts and that can potentially be used for phage therapy of some human bacterial diseases. These phages present non-enveloped virions with a head-to-tail structure, a dsDNA genome, and belong to group 1 of the Baltimore classification. All constructed profile HMMs were evaluated in regard to their sensitivity and specificity of detection, as well as tested in viral surveys using metagenomic data from the SRA database. The profile HMMs presented excellent performance, proving the viability of the methodology proposed in this project. The results presented in this work open the perspective of the wide use of profile HMMs as universal tools for the detection and classification of viruses in metagenomic data.

Keywords: Hidden Markov models, Virus detection, Metagenomics, Molecular markers, Viral taxonomy, Profile HMMs. 


\section{Lista de Abreviaturas}

$\begin{array}{ll}\text { BLAST } & \text { Basic Local Alignment Search Tool } \\ \text { CHIKV } & \text { Chikungunya virus } \\ \text { EEV } & \text { Eastern Equine Encephalitis Virus } \\ \text { ENA } & \text { European Nucleotide Archive } \\ \text { HMM } & \text { Hidden Markov Model - Modelo Oculto de Markov } \\ \text { ICTV } & \text { International Committee on Taxonomy of Viruses } \\ \text { IPG } & \text { Identical Protein Groups } \\ \text { MADV } & \text { Madariaga virus } \\ \text { MSA } & \text { Multiple Sequence Alignment - Alinhamento de Múltiplas Sequências } \\ \text { MUSCLE } & \text { Multiple Sequence Comparison by Log- Expectation } \\ \text { NCBI } & \text { National Center for Biotechnology Information } \\ \text { NCPV } & \text { National Collection of Pathogenic Viruses } \\ \text { OMS } & \text { Organização Mundial da Saúde } \\ \text { PATRIC } & \text { Pathosystems Resource Integration Center } \\ \text { RT } & \text { Reverse transcriptase - Transcriptase reversa } \\ \text { SRA } & \text { Sequence Read Archive } \\ \text { TABAJARA } & \text { Tool for Alignment Block Analysis Joining Appropriate Rational } \\ \text { TSP } & \text { Approaches } \\ \text { WHO } & \text { Tail Sheath Protein - Proteína da Bainha da cauda } \\ & \text { World Health Organization - Organização Mundial da Saúde }\end{array}$




\section{Lista de Figuras}

Figura 1 - Fluxo de trabalho do programa TABAJARA........................................................ 10

Figura 2 - Árvore filogenética de máxima verossimilhança de RNA polimerase RNAdependente de vírus da ordem Bunyavirales ................................................... 11

Figura 3 - Estrutura típica de uma partícula viral da ordem Bunyavirales............................. 13

Figura 4 - Segmentos genômicos de vírus da família Hantaviridae, ordem Bunyavirales ...... 14

Figura 5 - Árvore filogenética de máxima verossimilhança construída a partir de sequências da proteína da bainha da cauda (Tail Sheath protein) de vírus da subfamília Spounavirinae.

Figura 6 - Estrutura da partícula viral tipicamente encontrada na subfamília Spounavirinae. 17

Figura 7 - Estrutura de uma partícula viral tipicamente encontrada em membros da família Togaviridae.

Figura 8 - Diagrama do genoma de ssRNA (+) de Alphavirus, o qual codifica as poliproteínas estrutural e não estrutural

Figura 9 - Atribuição automática de valores de corte (cutoff scores)

Figura 10 - Cladograma construído a partir das sequências da proteína terminase da família Myoviridae

Figura 11 - Cladograma construído a partir das sequências da TSP da família Myoviridae....43

Figura 12 - Árvore filogenética de sequências de poliproteína estrutural de vírus do gênero Alphavirus.

Figura 13 - Árvore filogenética de sequências de poliproteína não estrutural de vírus do gênero Alphavirus. 


\section{Lista de Tabelas}

Tabela 1 - Classificação de Baltimore para grupos de vírus.

Tabela 2 - Principais parâmetros do programa TABAJARA.

Tabela 3 - Características taxonômicas e biológicas dos trezes gêneros de vírus da ordem Buynavirales.

Tabela 4 - Vírus da subfamília Spounavirinae e seus hospedeiros.

Tabela 5 - Características taxonômicas e biológicas_de vírus da família Togaviridae.

Tabela 6 - Metagenomas obtidos na base $\operatorname{SRA}^{1}$ e utilizados na prospecção de vírus da ordem Bunyavirales.

Tabela 7 - Metagenomas obtidos na base $\mathrm{SRA}^{1}$ e utilizados na prospecção de vírus da subfamília Spounavirinae e da família Myoviridae.

Tabela 9 - Sequências obtidas na base de dados IPG $^{1}$ do NCBI de acordo com o grupo taxonômico e as proteínas da ordem Bunyavirales.

Tabela 10 - Conjuntos de sequências da subfamília Spounavirinae obtidas a partir da base de dados IPG ${ }^{1}$.

Tabela 11 - Sequências obtidas na base de dados IPG $^{1}$ do NCBI para espécies do gênero Alphavirus.

Tabela 12 - HMMs de perfil construídos pelo programa TABAJARA para famílias da ordem Bunyavirales. 34

Tabela 13 - HMMs de perfil construídos pelo programa TABAJARA para a discriminação de gêneros de famílias da ordem Bunyavirales. .35

Tabela 14 - HMMs de perfil específicos para a subfamília Spounavirinae, gerados pelo TABAJARA a partir de diferentes proteínas virais.

Tabela 15 - Sensibilidade de detecção dos HMMs de perfil derivados da proteína terminase frente a um conjunto padrão de 93 genomas da subfamília Spounavirinae. 38 
Tabela 16 - Sensibilidade de detecção dos HMMs de perfil derivados da proteína de bainha da cauda (tail sheath) frente a um conjunto padrão de 93 genomas da subfamília Spounavirinae.

Tabela 17 - HMMs de perfil derivados da proteína terminase frente a um conjunto de 1.083 sequências de terminase da família Myoviridae (com exceção de Spounavirinae).

Tabela 18 - HMMs de perfil derivados da proteína de bainha da cauda (Tail Sheath) frente a um conjunto de 1.240 sequências de bainha da cauda da família Myoviridae (com exceção de Spounavirinae).

Tabela 19 - HMMs de perfil gerados pelo programa TABAJARA a partir de alinhamentos de múltiplas sequências de poliproteína estrutural e não estrutural de vírus da família Togaviridae. 45

Tabela 20 - Grupos de vírus selecionados a partir de dados filogenéticos (Figuras 12 e 13) para a construção de HMMs de perfil.

Tabela 21 - HMMs de perfil gerados pelo programa TABAJARA a partir de alinhamentos de múltiplas sequências de poliproteína estrutural e não estrutural de vírus do gênero Alphavirus. 48

Tabela 22 - Resultados gerados pelo programa HMM-prospector para uma prospecção com HMMs de perfil da ordem Bunyavirales contra o metagenoma SRR5185734 ....50

Tabela 23 - Resultados gerados pelo programa HMM-prospector para uma prospecção com HMMs de perfil da subfamília Spounavirinae contra o metagenoma SRR6764339.

Tabela 24 - Resultados gerados pelo programa HMM-prospector para uma prospecção com HMMs de perfil da família Togaviridae contra o metagenoma SRR7617262......53 


\section{Sumário}

1 Introdução.

1.1 A diversidade molecular e estrutural dos vírus

1.2 Metagenômica e prospecção viral 4

1.3 TABAJARA 8

$\begin{array}{ll}1.4 \text { Vírus da ordem Bunyavirales } & 11\end{array}$

1.4.1 Classificação taxonômica e importância ..................................................... 11

1.4.2 Composição e estrutura das partículas virais..............................................13

$\begin{array}{ll}1.5 \text { Vírus da subfamília Spounavirinae } & 15\end{array}$

1.5.1 Classificação taxonômica e importância .................................................... 15

1.5.2 Composição e estrutura das partículas virais.............................................. 16

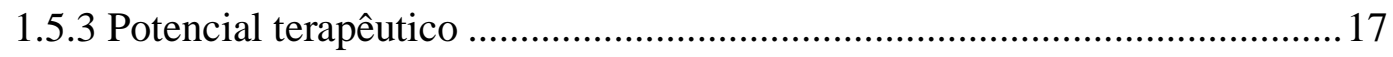

$\begin{array}{ll}1.6 \text { Vírus da família Togaviridae } & 18\end{array}$

1.6.1 Classificação taxonômica e importância ....................................................18

1.6.2 Composição e estrutura das partículas virais............................................. 19

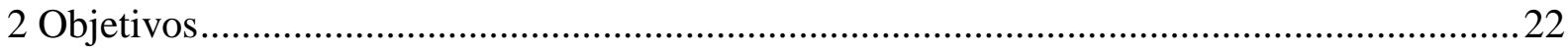

2.1 Objetivo geral 22

2.2 Objetivos específicos $\quad 22$

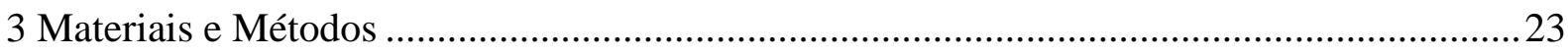

3.1 Obtenção de dados 23

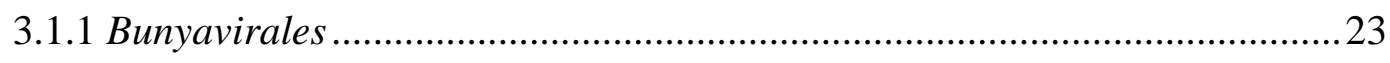

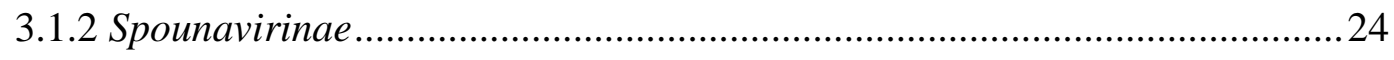

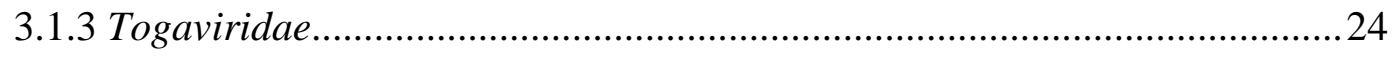

3.2 Alinhamento de múltiplas sequências $\quad 24$

3.3 Construção dos HMMs de perfil com o programa TABAJARA 25

3.4 Reconstrução filogenética de sequências virais 25

3.5 Prospecção de vírus em metagenomas 26

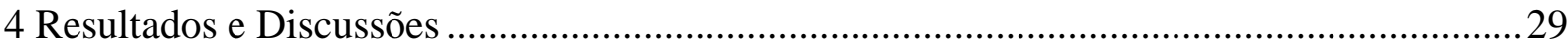

4.1 Obtenção de sequências a partir da base de dados IPG 29

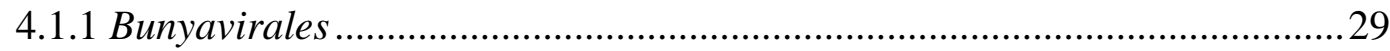

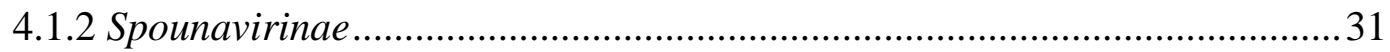




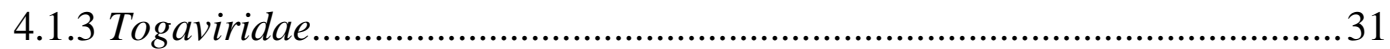

4.2 Construção e validação dos HMMs de perfil 33

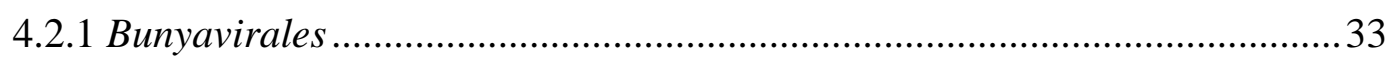

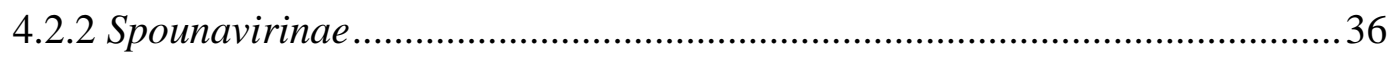

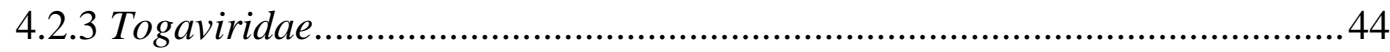

4.3 Prospecção de vírus em metagenomas 48

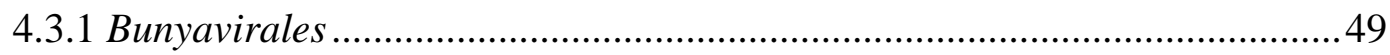

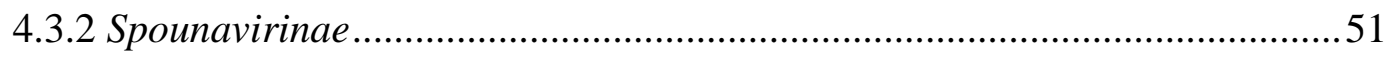

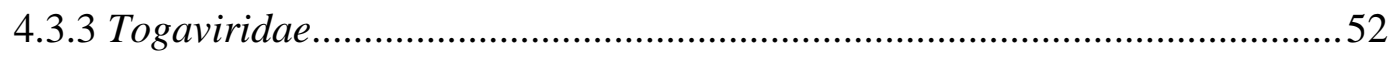

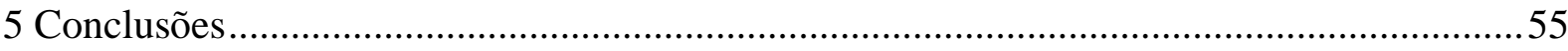

5.1 Perspectivas futuras do trabalho 55

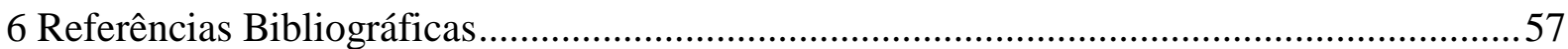




\section{Introdução}

\subsection{A diversidade molecular e estrutural dos vírus}

Segundo Fuhrman (1999), os vírus são provavelmente os seres mais abundantes da Terra (cf. Ackermann \& DuBow, 1987). Os vírus são descritos como organismos amplamente encontrados em ambientes aquáticos (Bergh et al., 1989; Fancello et al., 2013), solos (Segobola et al., 2018), plantas (Beijerinck, 1898; Navarro et al., 2018), no homem (Hontz et al., 2015; Tang et al., 2016) e nos demais animais (Tigertt \& Downs, 1962; Casseb et al., 2015). Em geral, os vírus não são considerados entidades vivas pelo fato de não terem autonomia em termos de replicação e uso de energia, entre outros aspectos. Contudo, esses organismos compartilham com seres vivos algumas características como possuir um genoma composto de um ácido nucleico, bem como serem constituídos de outras macromoléculas como proteínas, glicoconjugados e também de moléculas com uma construção modular como os lipídeos. Podemos encontrar também uma relação benéfica entre vírus e bactérias já que os vírus fornecem ao hospedeiro componentes como carbono, nitrogênio e fosfato e as bactérias necessitam para a sua constituição celular e ciclo de vida desses componentes orgânicos e inorgânicos (Fuhrman, 1999). Como os vírus não dispõem de uma maquinaria enzimática autônoma própria, dependem de uma célula hospedeira para se replicar e estabelecer sua progênie viral. $\mathrm{O}$ processo de adaptação rápida a novos hospedeiros exige uma alta taxa de mutação dos vírus que é inversamente proporcional ao tamanho do genoma (Gago et al., 2009). A taxa de mutação, isto é, a frequência de mutação previsível ao ano, é influenciada por diversos fatores como por exemplo pela taxa de mutação espontânea que pode ser originada por erros das polimerases durante a replicação do genoma viral, estes erros são passados para a progênie devido a ausência de mecanismos de reparo de alguns vírus. Eventos de recombinação genética e de rearranjos genéticos também podem ocorrer entre vírus segmentados e nos vírus de ssRNA(+) (Medeiros et al., 2015) influenciando na composição do genoma viral e na taxa de mutação. Segundo Sanjuán \& Domingo-Calap (2016) outro fator que influencia na taxa de mutação do vírus é a pressão de seleção específica resultante de múltiplos processos dependentes do vírus e seus hospedeiros. Como por exemplo, macrófagos podem realizar a fagocitose de partículas virais do vírus Influenza A e auxiliar na resposta imune adaptativa do homem via apresentação de antígeno às células T. Porém, estas células acabam selecionando concomitantemente as partículas virais mais resistentes que tem capacidade de se replicar 
dentro dos macrófagos, favorecendo assim o enriquecimento da progênie viral mais adaptada aos macrófagos do hospedeiro (Cline, Beck \& Bianchini, 2017). Com as altas taxas de mutação observadas em vírus se comparada a eucariotos e procariotos, podemos observar dois efeitos: um efeito negativo que seria na adaptação do vírus ao atual vetor e hospedeiro devido ao limiar da viabilidade genética que seleciona quais são as características essenciais para a propagação do vírus no hospedeiro ou em contrapartida, um efeito evolutivo bastante benéfico, aumentando o espaço genético(nicho) e permitindo aos vírus cruzar a barreira de espécies, incrementando a variedade de vetores e hospedeiros (Medeiros et al., 2015). Tal mecanismo poderia explicar a transmissão do vírus Ebola a partir de um reservatório animal, provavelmente morcegos, para humanos e, ainda permitir a sua adaptação entre indivíduos humanos (Urbanowicz et al., 2016). Um exemplo da dinâmica evolutiva de vírus foi recentemente descrito por Yosef et al. (2016). Usando o fago T7 como modelo, esses autores demonstraram que esses organismos podem infectar hospedeiros com receptores alterados por um reconhecimento "acidental" devido as próprias mutações espontâneas que naturalmente ocorrem nos receptores e no genoma do fago. Contudo, uma vez inserido no novo hospedeiro, a partir do genoma viral mais apto (stamping machine), ou seja, do vírus que conseguiu infectar o hospedeiro com receptores alterados, ocorrem novas mutações espontâneas que somam ao acúmulo de mutações da progênie viral por meio de seleção natural.

Vírus apresentam uma grande variedade de material genético, com genomas de DNA e RNA, de fita simples ou dupla, com topologia circular e linear, e com segmentos únicos ou múltiplos. Frente a essa enorme diversidade, Baltimore (1971) propôs uma classificação dos vírus (Tabela 1) que se tornou clássica e permite estabelecer os relacionamentos entre genomas virais e os caminhos que levam ao mRNA. A classificação original propôs seis grupos, os quais atualmente são acrescidos de um sétimo, representado por vírus com genoma de dupla fita parcial de DNA, o qual é composto por uma fita completa e outra contendo lacunas, e que utiliza moléculas de ssRNA(+) como intermediárias de replicação, sintetizadas com a enzima RNA polimerase dependente de RNA (RdRp) 
Tabela 1 - Classificação de Baltimore para grupos de vírus.

\begin{tabular}{ll}
\hline Grupo & Material Genético \\
\hline I & DNA dupla fita \\
II & DNA fita simples positiva \\
III & RNA dupla fita \\
IV & RNA fita simples positiva \\
V & RNA fita simples negativa \\
VI & RNA fita simples positiva RT \\
VII & DNA dupla fita RT \\
\hline
\end{tabular}

As proteínas não estruturais encontradas nos vírus também apresentam uma enorme diversidade. Dentre elas, as polimerases são as proteínas mais frequentemente encontradas e são responsáveis pelo processo de replicação e/ou transcrição viral. Dependendo do tipo de ácido nucléico presente no genoma viral, as polimerases podem ser DNA- ou RNAdependentes. Além disso, o processo de replicação viral pode incluir ou não moléculas intermediárias. Assim, DNA polimerases DNA-dependentes são tipicamente encontradas nos vírus do grupo I de Baltimore e realizam a replicação do DNA viral. RNA polimerases DNAdependentes também podem ser encontradas nos vírus do grupo I e II e realizam a transcrição da fita de DNA do vírus em uma fita de RNA mensageiro. As DNA polimerases RNAdependentes, também conhecidas como transcriptases reversas, podem ser encontradas nos vírus dos grupos VI e VII de Baltimore e realizam a transcrição de uma fita de RNA em uma fita de DNA. Finalmente, as RNA polimerases dependentes de RNA estão presentes nos vírus dos grupos III, IV e V e realizam a replicação do RNA dos vírus. A diversidade das polimerases parece em termos de origens filogenéticas bastante ampla. Zanotto et al. (1996) demonstraram que a estrutura primária de RNA polimerases RNA-dependentes não podem ser usadas para definir uma árvore filogenética congruente que inclua todos os vírus de RNA. De fato, os autores não encontraram suporte para embasar a hipótese de monofilia das RNA polimerases e concluíram que a presença de motivos conservados nas várias RNA polimerases RNAdependentes poderiam ter sido fruto de evolução convergente. Por outro lado, Černý et al. (2015) realizando análises filogenéticas com dados de estrutura primária das polimerases e informações adicionais como estrutura terciária e características funcionais, concluíram que as RNA polimerases RNA-dependentes e as transcriptases reversas de retrovírus formavam grupos monofiléticos irmãos, distinguíveis de outras polimerases. Esses dois trabalhos (Zanotto et al., 1996; Černý et al. 2015) mostram, portanto, que dada a alta divergência dos vírus de 
RNA, suas sequências proteicas são muito distantemente relacionadas e que somente pela adição de outros caracteres como características tridimensionais e funcionais pode-se obter árvores filogenéticas com bom suporte.

A alta diversidade dos vírus se reflete ainda em outros aspectos, além da composição do genoma e seu mecanismo de replicação. O conteúdo genético pode estar contido dentro de uma capa proteica ou lipídica. A capa proteica denominada capsídeo, pode também apresentar uma enorme variedade de forma e estrutura. Assim, os capsídeos são formados por subunidades denominadas protômeros que podem ser simétricos ou não simétricos e estes são compostos por unidades estruturais básicas (Luque et al., 2018). Os protômeros podem comumente constituir capsídeos com forma de icosaedro, um poliedro com 20 faces triangulares. Bacteriófagos, por sua vez, podem ter uma forma ainda mais complexa, composta de uma cabeça icosaédrica, uma cauda e projeções denominadas fibras, entre outros elementos estruturais (Tavares, 2018). Outra forma de capsídeo apresenta simetria helicoidal e ocorre em vírions com formato de bastão, como no vírus do mosaico do tabaco da família Virgaviridae (https://viralzone.expasy.org/51). Essa alta diversidade morfológica e estrutural dos capsídeos virais é fruto da grande variedade de formas que os protômeros podem constituir.

Alguns vírus apresentam uma estrutura envelopada que pode ser derivada de membranas da célula do hospedeiro, de vesículas associadas ao retículo endoplasmático e/ou ao complexo de Golgi. Esta estrutura circunda o material genético do vírus, separada do mesmo por pelo menos uma camada proteica, com exceção de alguns vírus de bactérias e arqueias, nos quais a membrana envolve diretamente o genoma (Flint et al., 2015). O envelope contém proteínas integrais, em geral glicoproteínas, como se observa em vírus da ordem Bunyavirales (Guardado-Calvo \& Rey, 2017), Alphavirus e Flavivirus (Helenius, 1995). Essas glicoproteínas estão diretamente relacionadas ao processo de reconhecimento de receptores na superfície celular do hospedeiro e têm papel no processo de fusão da membrana do vírus com a membrana do hospedeiro (Sakurai, 2015). As glicoproteínas podem ser apresentadas de diversas formas, como trímeros (Martin et al., 2016) e heterodímeros (Elliot, 1990) denominados spike e são responsáveis pelo tropismo celular do vírus.

\subsection{Metagenômica e prospecção viral}

Técnicas clássicas de estudo de vírus consistem no isolamento e propagação in vitro do vírus e seu respectivo hospedeiro. Contudo, elas necessitam de um conhecimento prévio sobre 
o ciclo de vida do vírus, de quais são seus hospedeiros, além de informações sobre as condições adequadas para o cultivo do vírus no seu hospedeiro e o cultivo do hospedeiro infectado em placas de cultura, assim, apenas uma pequena fração desses organismos acaba sendo cultivada. A metagenômica surge como uma alternativa em contrapartida as técnicas clássicas de estudo de vírus pois consiste, na análise genômica de microrganismos em um determinado ambiente por técnicas independentes de cultivo. A pesquisadora Handelsman et al. (1998) em seu trabalho propôs pela primeira vez o termo metagenômica que visava o estudo de microrganismos presentes no solo que não eram cultiváveis. A partir de 2002, a metagenômica começou a ser utilizada no campo da virologia e a apresentar várias vantagens em relação aos métodos clássicos de descoberta de novos vírus. Na metagenômica, amostras contendo vírus podem ser coletadas e analisadas sem a necessidade de cultivo prévio, podendo abranger uma ampla diversidade. Três etapas são envolvidas nessa metodologia: preparação da amostra (coleta e purificação), sequenciamento e análises bioinformáticas (Mokili, Rohwer \& Dutilh, 2012). Nessa última etapa, a detecção e classificação das sequências é feita utilizando-se em geral buscas de similaridade. O BLAST (Johnson et al., 2008) é a ferramenta computacional mais amplamente utilizada em buscas de similaridade, porém essa ferramenta é capaz de identificar apenas uma fração das proteínas que compartilham entre si de 20-30\% de identidade (Brenner et al., 1998). Mokili et al. (2012) fizeram um levantamento de estudos de metagenômica de vírus na literatura e demonstraram que na maioria dos casos, a maior parte das leituras geradas não conseguia ser classificada por buscas de similaridade com o BLAST.

Uma complexa variedade de razões pode explicar esses resultados. Primeiramente, a quantidade relativamente pequena de sequências virais em bases de dados públicas e as limitações da abordagem de busca de similaridade como método para a detecção e classificação de sequências virais. As bases de dados públicas apresentam de fato uma baixa representação da diversidade viral encontrada na natureza (Edwards \& Rohwer, 2005; Fancello et al., 2012; Reyes et al., 2017). Por exemplo, a base Viral Genomes do NCBI (Brister et al., 2014) apresentava apenas 8113 genomas virais completos (https://www.ncbi.nlm.nih.gov/genome/viruses/ - acesso em 26 nov 2018), enquanto a base Virus-Host DB (https://www.genome.jp/virushostdb/), uma fonte integrada de dados de relacionamentos entre vírus e seus hospedeiros, apresentava 10.597 entradas relacionadas a dados genômicos virais (acesso em 27 nov 2018). Em comparação com esses resultados, a base Genome do NCBI (https://www.ncbi.nlm.nih.gov/genome/ - acesso em 27 nov 2018) continha 
175.603 sequências de genomas de organismos procariotos. A base PATRIC (Wattam et al., 2016 - https://www.patricbrc.org/), outra importante fonte de dados genômicos, apresenta atualmente (acesso em 26 nov 2018) um total de 192.717 genomas de bactérias, arqueias e alguns organismos eucarióticos. Esses levantamentos demonstram claramente que embora os vírus sejam os organismos mais abundantes da natureza e apresentem genomas extremamente variantes com uma alta taxa de mutação, sua representação em bases de dados de sequências ainda é proporcionalmente muito inferior já que organismos procariotos são muito mais fáceis de se cultivar. Outro aspecto particularmente importante é que mesmo essa baixa representação é ainda por cima muito enviesada, com uma fração muito grande dos dados sendo derivada de alguns patógenos de maior relevância em medicina humana.

Outro importante aspecto que dificulta as buscas de similaridade é a alta divergência observada entre os vírus. De fato, os vírus apresentam altas taxas de mutação (Drake, 1993; Holland et al., 1982; Sanjuán et al., 2010) o que resulta em taxas de substituição muito superiores às observadas em organismos procarióticos e eucarióticos. Conforme apresentado no item anterior, os vírus apresentam diferentes composições nos seus genomas, resultando numa ampla variedade de polimerases envolvidas na replicação e transcrição dos genomas virais, sem necessariamente apresentar uma origem filogenética comum (Zanotto et al., 1996; Černý et al. 2015). Além disso, como também comentado no item anterior, os vírus apresentam uma grande diversidade de tipos de capsídeos e, consequentemente, das proteínas que compõem esses capsídeos. Finalmente, a presença de um envelope não é uma característica universal entre os vírus e as proteínas integrais presentes nessa estrutura podem ser totalmente diferentes entre distintos grupos virais. Concluindo, a enorme diversidade que podemos encontrar em proteínas estruturais e não estruturais de vírus faz com que não seja possível encontrar um marcador universal que represente todos os vírus que existem (Rohwer \& Edwards, 2002; Reyes et al., 2017). Esse é um cenário muito diferente daquele que se observa em organismos procariotos, nos quais o gene da subunidade ribossômica pequena (16 S SSU rRNA) é usado como marcador universal para a classificação e estudos filogenéticos. Também em eucariotos existem marcadores universais como os genes da subunidade ribossômica grande (28S LSU rRNA) e citocromo b mitocondrial. A existência de altas taxas de substituição, aliada à falta de marcadores moleculares universais, torna a identificação e classificação de sequências virais muito mais desafiadores do que em organismos celulares.

Um terceiro aspecto que limita a identificação de sequências virais é a limitada sensibilidade dos métodos de alinhamento pareado, representados majoritariamente pelos 
programas do pacote BLAST. Brenner et al. (1998) demonstraram que métodos de busca de similaridade pareada são capazes de detectar apenas metade das proteínas que apresentam de 20 a 30\% de resíduos idênticos. Considerando-se a alta taxa de evolução dos vírus, é relativamente comum que vírus de um mesmo grupo taxonômico apresentem similaridades tão baixas ou mesmo inferiores. Park et al. (1998), por outro lado, mostraram que métodos baseados em perfis podem aumentar a sensibilidade de detecção de homólogos filogeneticamente distantes. HMMs de perfil (Eddy, 1998) são modelos probabilísticos construídos a partir de um alinhamento de múltiplas sequências (ver Apêndice A), que são capazes de modelar a diversidade de resíduos em cada posição do alinhamento, podendo ser usados para a detecção e classificação de sequências virais. Existem várias bases de dados públicas de HMMs de perfil como o TIGRFAMs (Haft, Selengut e White, 2003), PANTHER (Thomas et al., 2003), Pfam (Bateman et al., 2004), vFAM (Skewes-Cox et al., 2014), eggNOG4.5 (Huerta-Cepas et al., 2015) e pVOGs (Grazziotin, Koonin \& Kristensen, 2016). Dessas bases, o vFAM, pVOGs e a seção Viruses do eggNOG oferecem modelos representativos de grupos virais. Os HMMs de perfil disponíveis nestes bancos de dados podem ser utilizados para a caracterização de dados metagenômicos.

A utilização dos HMMs de perfil das bases de dados acima, contudo, apresenta alguns problemas. De acordo com o levantamento apresentado por Reyes et al. (2017), a maioria dos modelos dessas bases foram construídos com um pequeno número de sequências e representam um baixo número de grupos virais. Além disso, os modelos derivam de alinhamentos cujas sequências foram selecionadas a partir de grupos de ortologia que não têm necessariamente relação com grupos taxonômicos específicos. Finalmente, por terem sido construídos com sequências de proteínas inteiras, os alinhamentos utilizados cobrem regiões conservadas e não conservadas, implicando que regiões específicas do alinhamento podem ter apresentado grande número de vãos (gaps), o que introduz ruído e é muito ruim para a construção de modelos probabilísticos. Além disso, proteínas podem ter regiões altamente específicas de um grupo viral e outras altamente conservadas em múltiplos grupos ou até mesmo em organismos celulares no caso de algumas proteínas. Para se utilizar HMMs de perfil de origem viral para a detecção e classificação específica de grupos virais, o processo de construção dos modelos teria que ser centrado no aspecto taxonômico, e não apenas em critérios de ortologia. Para isso, nosso grupo desenvolveu um conjunto de abordagens metodológicas que incluem o TABAJARA, um programa para o desenho racional de HMMs de perfil a partir de alinhamentos de múltiplas sequências. 


\subsection{TABAJARA}

O programa TABAJARA foi desenvolvido em nosso laboratório, na linguagem de programação Perl, pela doutoranda Liliane Santana Oliveira na sua tese. Um resumo descrevendo a aplicação foi reportado por Ibrahim et al. (2018). O programa utiliza um alinhamento de múltiplas de sequências (nucleotídicas ou proteicas) como arquivo de entrada e trabalha com duas abordagens para a construção dos modelos probabilísticos: modo conservação ou modo discriminação. No modo conservação, o programa identifica os blocos do alinhamento mais conservados para o conjunto das sequências. No modo discriminação, o TABAJARA seleciona blocos do alinhamento que discriminam um grupo de sequências das demais sequências do conjunto de treinamento. Inicialmente, o TABAJARA calcula um escore para cada posição do alinhamento. A forma como esse escore é calculado depende da abordagem utilizada. No modo conservação, o TABAJARA calcula um escore para cada coluna do MSA aplicando o método de Jensen-Shannon (Capra \& Singh, 2007) se as sequências do alinhamento forem proteicas ou Entropia de Shannon (Shannon, 2001), se as sequências forem nucleotídicas. No modo discriminação, o TABAJARA calcula um escore para cada coluna do MSA aplicando o cálculo de Informação Mútua (Adami, 2004) ou o método de Harmonia de Sequências (Feenstra et al., 2007), independentemente das sequências (nucleotídica ou proteica) presentes no MSA. A Tabela 2 lista os parâmetros que podem ser especificados pelo usuário para a execução do programa TABAJARA. A partir do cálculo dos escores posiçãoespecíficos, as regiões conservadas ou informativas são selecionadas com o uso de janelas deslizantes. Regiões apresentando janelas válidas sobrepostas acabam compondo os blocos selecionados de alinhamento. Quando há uma lacuna entre blocos, estes podem ser unidos dependendo do valor estabelecido pelo uso do parâmetro (-md), que define a distância máxima permitida entre blocos para sua junção em um único. Os blocos assim obtidos são extraídos e utilizados como entrada para o programa hmmbuilder. O hmmbuilder é uma ferramenta do pacote HMMER (Eddy, 2011) que constrói os HMMs de perfil a partir dos alinhamentos múltiplos. 
Tabela 2 - Principais parâmetros do programa TABAJARA.

\begin{tabular}{|c|c|}
\hline Parâmetro & Descrição \\
\hline$(-\mathrm{w})$ & Tamanho da janela deslizante. \\
\hline$(-\mathrm{p})$ & $\begin{array}{l}\text { Percentual de posições dentro da janela deslizante que devem ter escore igual ou } \\
\text { acima do valor limiar determinado pelo usuário }(-t) \text {. }\end{array}$ \\
\hline$(-t)$ & $\begin{array}{l}\text { Escore limiar determinado pelo usuário como um dos critérios para aceitação da } \\
\text { janela deslizante. }\end{array}$ \\
\hline$(-b)$ & Tamanho mínimo do modelo. \\
\hline$(-\mathrm{mb})$ & Tamanho máximo do modelo. \\
\hline$(-\mathrm{m})$ & $\begin{array}{l}\text { Método utilizado para a construção do modelo no modo conservação }\left(\begin{array}{ll}-m & c\end{array}\right) \\
\text { ou no modo discriminação }\left(\begin{array}{ll}-m & b\end{array}\right)\end{array}$ \\
\hline$(-\mathrm{CS})$ & $\begin{array}{l}\text { Adição do cutoff score ao cabeçalho do modelo (-CS yes) ou não (-cS } \\
\text { no). }\end{array}$ \\
\hline$(-s a)$ & $\begin{array}{l}\text { Número mínimo de sequências que pode compor os blocos selecionados para a } \\
\text { construção dos modelos. }\end{array}$ \\
\hline$(-g c)$ & Percentual máximo de gaps aceito em cada coluna do MSA. \\
\hline$(-C)$ & $\begin{array}{l}\text { Quando há mais de uma categoria no conjunto de treinamento em que há o } \\
\text { interesse de construir modelos, o nome da categoria é adicionado logo em } \\
\text { seguida deste parâmetro, sendo o nome das categorias separados por vírgula. }\end{array}$ \\
\hline$(-s v)$ & Limiar mínimo do valor do cutoff score para cada modelo. \\
\hline$(-d i)$ & Eliminar as sequências redundantes do MSA (-di yes) ou não (-di no) \\
\hline
\end{tabular}

Após a geração dos HMMs de perfil de cada bloco, os modelos gerados são submetidos a um processo automático de validação. Para isso, o TABAJARA utiliza a ferramenta hmmsearch para a busca de similaridade entre os modelos e as sequências do conjunto de treinamento. O processo de validação considera o percentual mínimo de sequências do conjunto de treinamento que são detectadas pelo modelo. Além disso, o programa implementa um método para estabelecer escores de corte (cutoff scores) personalizados para cada modelo. Esses valores são inseridos com uma etiqueta ( $t a g$ ) no cabeçalho dos modelos e permitem aumentar a especificidade dos resultados, além de poder ser usados posteriormente por outros programas que estejam habilitados para ler essa etiqueta. A Figura 1 mostra o fluxo de trabalho do programa TABAJARA, com as diferentes etapas. Como o TABAJARA ainda não está publicado, pode-se obter uma versão rascunho de seu manual de uso no endereço http://www.bioinfovir.icb.usp.br/TABAJARA_manual.pdf. Esse programa permite, portanto, a construção de HMMs de perfil a partir de MSAs capazes de detectar todas as sequências de um conjunto, ou grupos específicos de sequências. Se as sequências forem derivadas de grupos 
taxonômicos específicos, é possível desenhar modelos com diferentes graus de especificidade taxonômica.

No presente trabalho será descrita a aplicação do programa para a construção de HMMs de perfil com diferentes especificidades taxonômicas. Para isso, foram escolhidos três modelos de estudo, compreendendo vírus de ssRNA(-) da ordem Bunyavirales, vírus ssRNA(+) da família Togaviridae e bacteriófagos de dsDNA da subfamília Spounavirinae. As seções seguintes apresentam um pequeno levantamento acerca desses grupos virais.

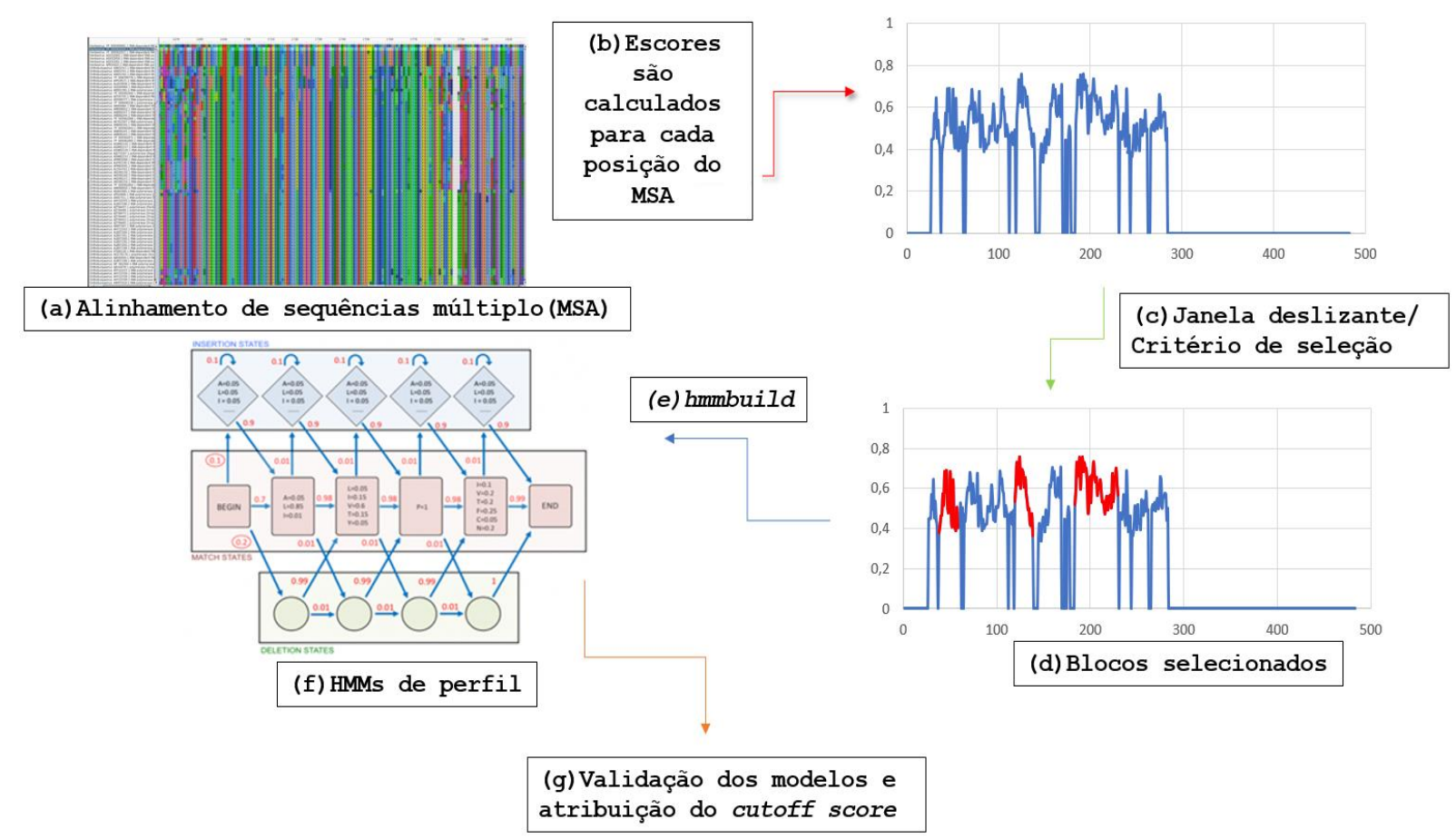

Figura 1 - Fluxo de trabalho do programa TABAJARA. Um arquivo de alinhamento de múltiplas sequências é utilizado como entrada de dados (a). Dependendo do método escolhido, escores são atribuídos para cada posição (b) e, posteriormente, através de uma abordagem de janela deslizante (c), os melhores blocos de alinhamento são selecionados (d). Esses blocos são utilizados pela ferramenta hmmbuild (e) para a construção dos HMMs de perfil (f), os quais são submetidos a rotinas de validação com testes de sensibilidade e especificidade frente às sequências do conjunto de treinamento $(\mathrm{g})$. 


\subsection{Vírus da ordem Bunyavirales}

\subsubsection{Classificação taxonômica e importância}

Os vírus pertencentes à ordem Bunyavirales estão presentes em todos os continentes do mundo, tendo sido descritos em diversos países (Hobson-Peters et al., 2016; Sibhat et al., 2018; Pauvolid-Corrêa et al., 2017). A ordem Bunyavirales pertence ao Grupo 5 da classificação de Baltimore (Baltimore, 1971), correspondente a vírus de ssRNA(-). De acordo com o International Committee on Taxonomy of Viruses (https://talk.ictvonline.org/taxonomy/; Maes et al., 2018), a ordem é dividida em nove famílias (Figura 2).

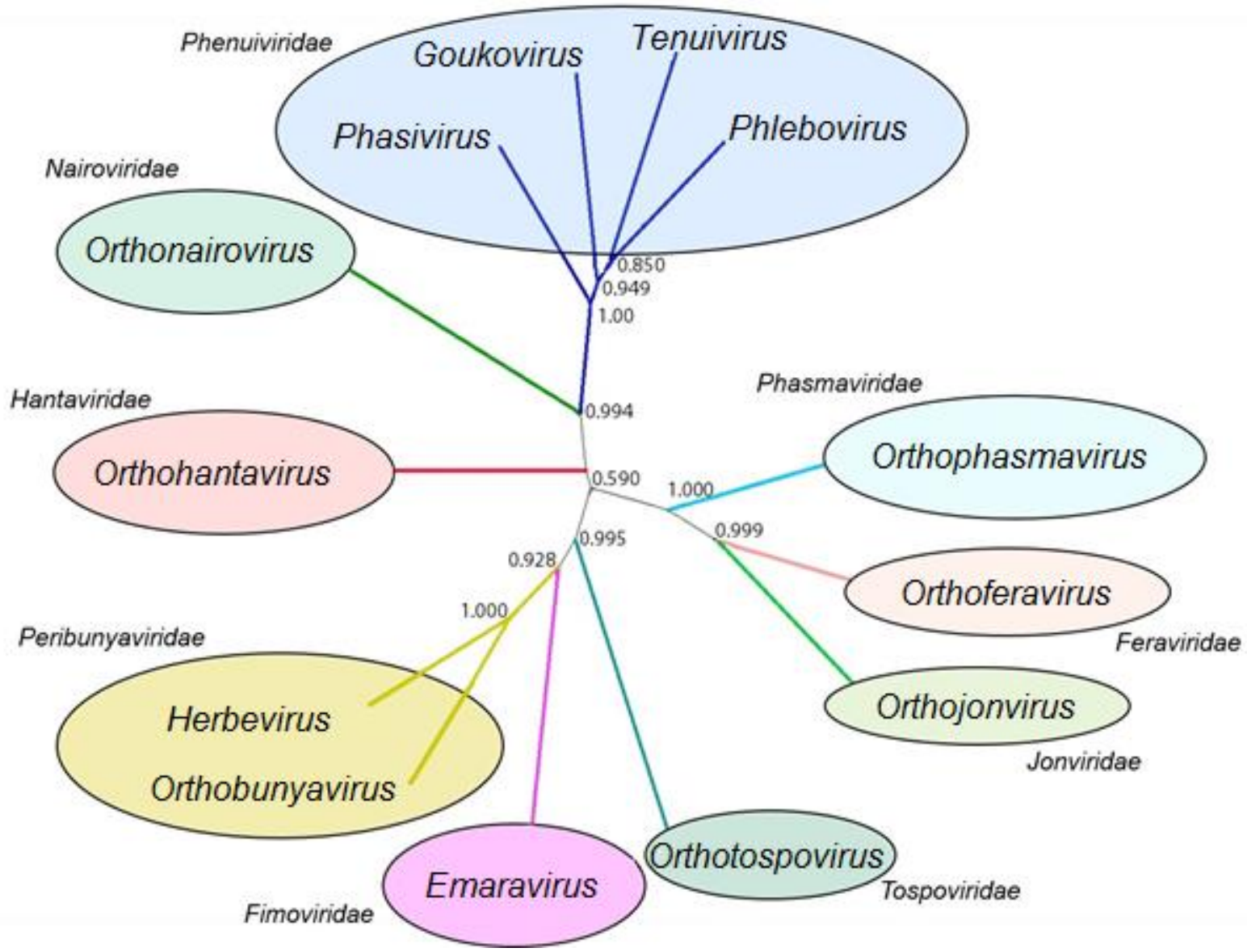

Figura 2 - Árvore filogenética de máxima verossimilhança de RNA polimerase RNAdependente de vírus da ordem Bunyavirales. As elipses coloridas representam as nove famílias contendo treze gêneros da ordem.

Várias doenças importantes são causadas por vírus desta ordem em humanos, animais e plantas. Algumas delas são fatais, como a doença causada pelo La Crosse virus (LACV- gênero Orthobunyavirus), e podem causar encefalites, hepatites, febre hemorrágica, falha renal, entre 
outras consequências (Albornoz et al., 2016). A Tabela 3 lista famílias e gêneros da ordem Bunyavirales que são encontrados em vários países, com exemplos de seus respectivos hospedeiros e, quando pertinente, os sintomas observados.

Tabela 3 - Características taxonômicas e biológicas dos trezes gêneros de vírus da ordem Buynavirales.

\begin{tabular}{|c|c|c|c|c|}
\hline Família & Gênero & Espécie & Hospedeiro & Sintomas \\
\hline Feraviridae & Orthoferavirus & Ferak orthoferavirus & Invertebrados & - \\
\hline Fimoviridae & Emaravirus & $\begin{array}{l}\text { European mountain ash } \\
\text { ringspot-associated virus }\end{array}$ & Sorbus aucuparia & $\begin{array}{l}\text { Manchas em folhas } \\
\text { de plantas e } \\
\text { anêmonas. }{ }^{1}\end{array}$ \\
\hline Hantaviridae & Orthohantavirus & Hantaan vírus & Homem & $\begin{array}{l}\text { Febre alta, } \\
\text { insuficiência renal } \\
\text { e hemorragia. }^{2}\end{array}$ \\
\hline Jonviridae & Orthojonvirus & Jonchet orthojonvirus & Invertebrados & - \\
\hline Nairoviridae & Orthonairovirus & $\begin{array}{l}\text { Crimean Congo hemorrhagic } \\
\text { fever orthonairovirus }\end{array}$ & Homem & $\begin{array}{l}\text { Febre hemorrágica } \\
\text { (semelhante a } \\
\text { Dengue). } .^{3}\end{array}$ \\
\hline \multirow[t]{2}{*}{ Peribunyaviridae } & Herbevirus & Herbert herbevirus & Invertebrados & - \\
\hline & Orthobunyavirus & Oropouche vírus & Homem & $\begin{array}{l}\text { Febre e dor de } \\
\text { cabeça. }^{4}\end{array}$ \\
\hline Phasmaviridae & Orthophasmavirus & $\begin{array}{l}\text { Kigluaik phantom } \\
\text { orthophasmavirus }\end{array}$ & Chaoborus $^{5}$ & - \\
\hline \multirow[t]{4}{*}{ Phenuiviridae } & Goukovirus & Goukeako goukovirus & Invertebrados & - \\
\hline & Phasivirus & Badu phasivirus & Invertebrados & - \\
\hline & Phlebovirus & Rift Valley fever phlebovirus & $\begin{array}{l}\text { Ruminantes e } \\
\text { humanos }\end{array}$ & $\begin{array}{l}\text { Humanos: } \\
\text { Fraqueza muscular } \\
\text { (como no } \\
\text { Influenza) e } \\
\text { raramente febre } \\
\text { hemorrágica. } \\
\text { Gado: aborto. }\end{array}$ \\
\hline & Tenuivirus & Rice stripe tenuivirus & Arroz, milho e trigo & Clorose. $^{5}$ \\
\hline Tospoviridae & Orthotospovirus & Tomato spotted wilt vírus & Tabaco e tomate & $\begin{array}{l}\text { Redução geral no } \\
\text { porte da planta, } \\
\text { arroxeamento ou } \\
\text { bronzeamento das } \\
\text { folhas. }^{6}\end{array}$ \\
\hline
\end{tabular}

Fonte: ${ }^{1}$ Kallinen et al., 2009; ${ }^{2}$ Vratnica et al., 2017; ${ }^{3} \mathrm{WHO}, 2018$ (https://afro.who.int/health-topics/crimeancongo-haemorrhagic-fever); ${ }^{4}$ Naveca et al., 2018; ${ }^{5}$ Ballinger et al., 2017; ${ }^{5}$ ViralZone, 2018 (https://viralzone.expasy.org/502); ${ }^{6}$ Cho et al., 1995; 
O Brasil possui uma grande quantidade de arbovírus da ordem Bunyavirales. Os principais casos descritos no Brasil são referentes aos gêneros Orthobunyavirus (Oliveira et al., 2014), Phlebovirus (Casseb et al., 2015) e Orthohantavirus (Oliveira et al., 2014).

1.4.2 Composição e estrutura das partículas virais

Os vírions pertencentes à ordem Bunyavirales são geralmente envelopados, apresentam estrutura esférica e possuem diâmetro médio de 80-120 nm. O genoma linear é composto de três segmentos de RNA de fita simples negativa ssRNA(-) (Figura 3). A região próxima a extremidade 3' de cada um dos segmentos possui complementaridade de bases com a extremidade 5' do próprio segmento (Elliott, Schmalijohn \& Collet, 1991), o que justifica a conformação dos segmentos dentro da partícula viral observada na Figura 3. Os tamanhos dos segmentos L, M e S variam em função do gênero (Elliott, 1990) e podem variar entre 6,8-12 $\mathrm{kb}, 3,2-4,9 \mathrm{~kb}$ e 1-3 kb, respectivamente (Albornoz et al., 2016).

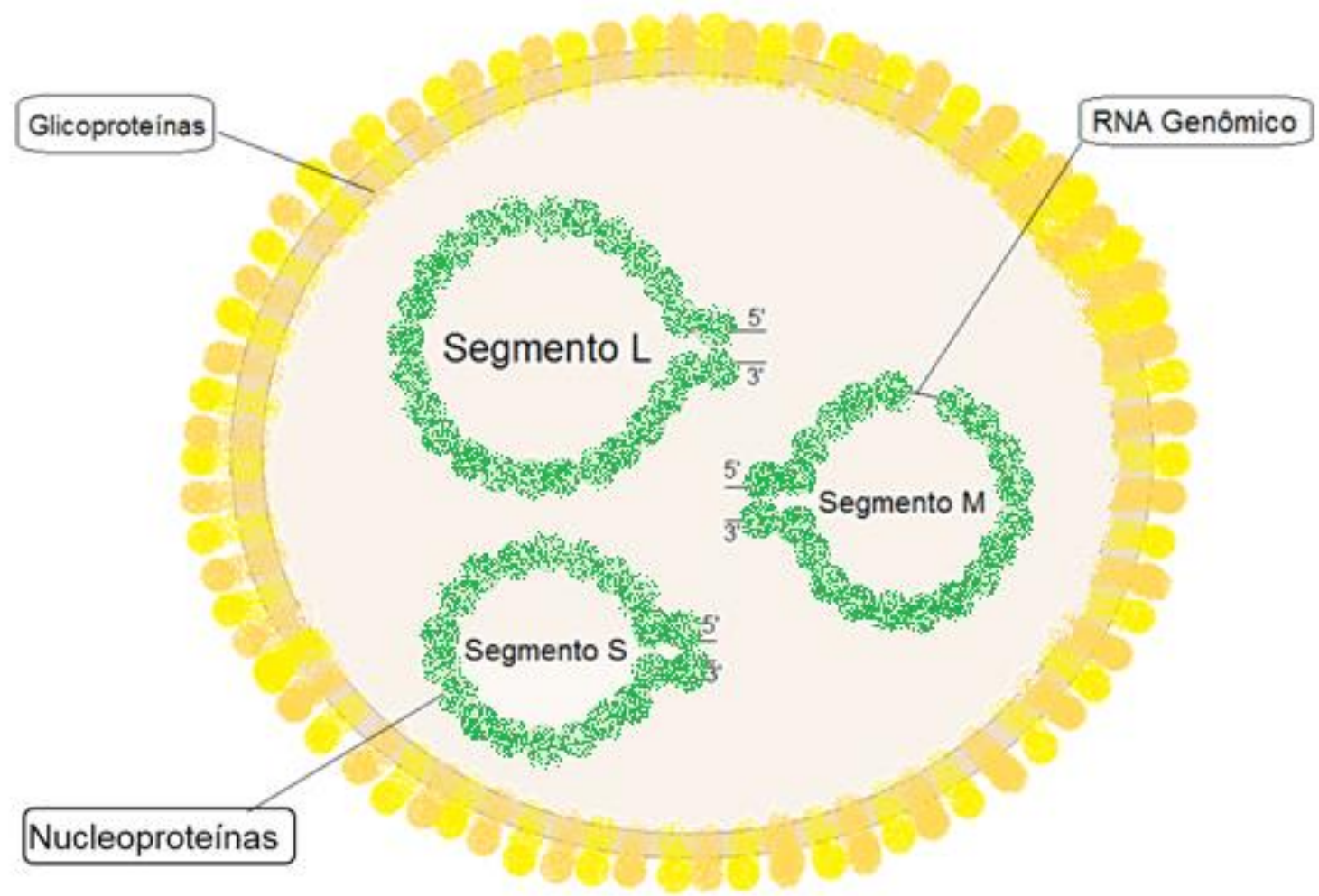

Figura 3 - Estrutura típica de uma partícula viral da ordem Bunyavirales. 
Os produtos gênicos codificados pelos segmentos variam de família para família, sendo geralmente encontrados como: RNA polimerase RNA-dependente (RdRp) codificada pelo segmento L, nucleoproteína $\mathrm{N}$ codificada pelo segmento $\mathrm{S}$ e a poliproteína precursora das glicoproteínas Gn e Gc codificada pelo segmento M, também denominadas G1 e G2 (ViralZone, 2018). Alguns dos segmentos (M e S) podem apresentar, dependendo do gênero, uma codificação ambisense, na qual alguns dos genes são codificados pela fita positiva (sense) e outras pela fita negativa (antisense). Um exemplo de estrutura genômica de vírus da família Hantaviridae está apresentada na Figura 4.

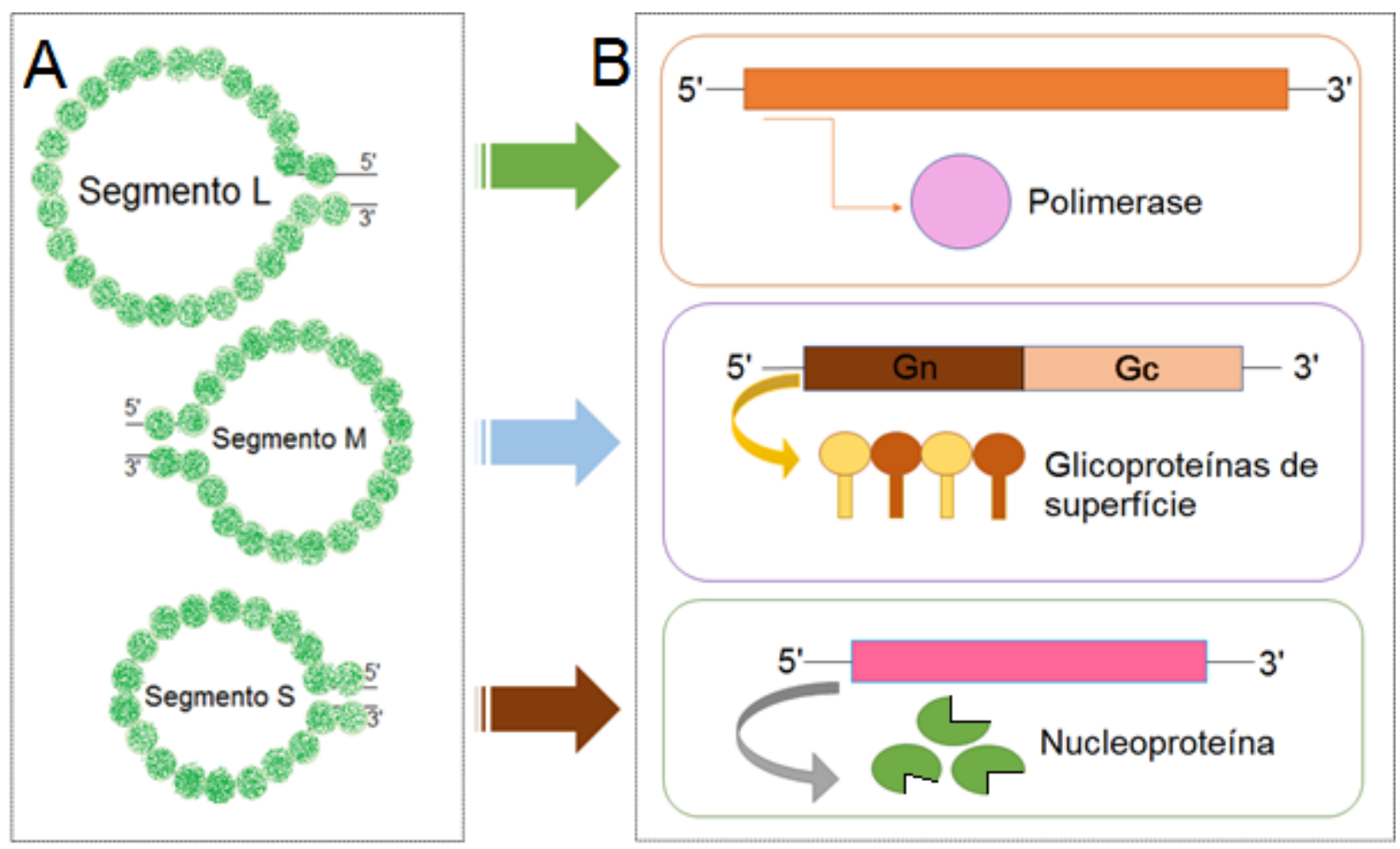

Figura 4 - Segmentos genômicos de vírus da família Hantaviridae, ordem Bunyavirales. Os segmentos são constituídos por ssRNA (-) com topologia linear (A) e extremidades 5' e 3' complementares. Cada segmento codifica uma ou mais proteínas (B).

As três proteínas representadas na Figura 4 estão presentes em todas as famílias da ordem Bunyavirales e possuem regiões específicas na estrutura primária que as diferenciam entre as diferentes famílias e gêneros. Podem ser encontradas várias sequências disponíveis publicamente representativas destas proteínas em bases de dados como NCBI, Uniprot e ENA. Assim, as proteínas: polimerases, glicoproteínas e nucleoproteínas podem ser utilizadas no desenho de candidatos a marcadores moleculares para vírus da ordem Bunyavirales. 


\subsection{Vírus da subfamília Spounavirinae}

\subsubsection{Classificação taxonômica e importância}

Observando a quantidade de fagos descobertos até o ano de 2003, Ackermann (2003) destacou que $96 \%$ dos fagos conhecidos pertencem à ordem Caudovirales. Os fagos desta ordem são classificados em 4 famílias segundo o ICTV (https://talk.ictvonline.org/ictvreports/ictv_9th_report/dsdna-viruses-2011/w/dsdna_viruses/67/caudovirales - Acessado em 10 dez 2018): Ackermannviridae, Myoviridae, Siphoviridae e Podoviridae.

A subfamília Spounavirinae, grupo que pertence à família Myoviridae, foi proposta por Lavigne et al. (2009) e tem como principais hospedeiros bactérias gram-positivas do filo Firmicutes (Klumpp et al., 2010). Estas bactérias possuem células susceptíveis e permissivas à infecção, tais como Bacillus, Staphylococcus, Listeria e Enterococcus (Kwan et al., 2005; Uchiyama et al., 2008; Uchiyama et al., 2012; Stewart et al., 2009). A Tabela 4 apresenta uma lista de algumas das espécies da subfamília viral Spounavirinae e seus respectivos hospedeiros.

Tabela 4 - Vírus da subfamília Spounavirinae e seus hospedeiros.

\begin{tabular}{llll}
\hline Gênero & Espécie & Hospedeiro & Referência \\
\hline Kayvirus & Staphylococcus virus G1 & Staphylococcus aureus & Kwan et al., 2005 \\
Pl00virus & Listeria virus A511 & Listeria monocytogenes & Habann et al., 2014 \\
SPO1-like viruses & Staphylococcal Bacteriophage 812 & Staphylococcus aureus & Kwiatek et al., 2012 \\
Spolvirus & Bacillus virus SPO1 & Bacillus subtilis & Klumpp et al., 2010 \\
Twortvirus & Staphylococcus virus Twort & Staphylococcus aureus & Willms et al., 2017 \\
Não classificado & Enterococcus virus phiEC24C & Enterococcus faecalis & Uchiyama et al., 2008 \\
Não classificado & Lactobacillus virus Lb338-1 & Lactobacillus paracasei & Alemayehu et al., 2009 \\
\hline
\end{tabular}

A subfamília Spounavirinae é composta de seis gêneros (ICTV, 2018) (Figura 5), sendo classificada como parte do Grupo 1 da classificação de Baltimore (Baltimore, 1971). 


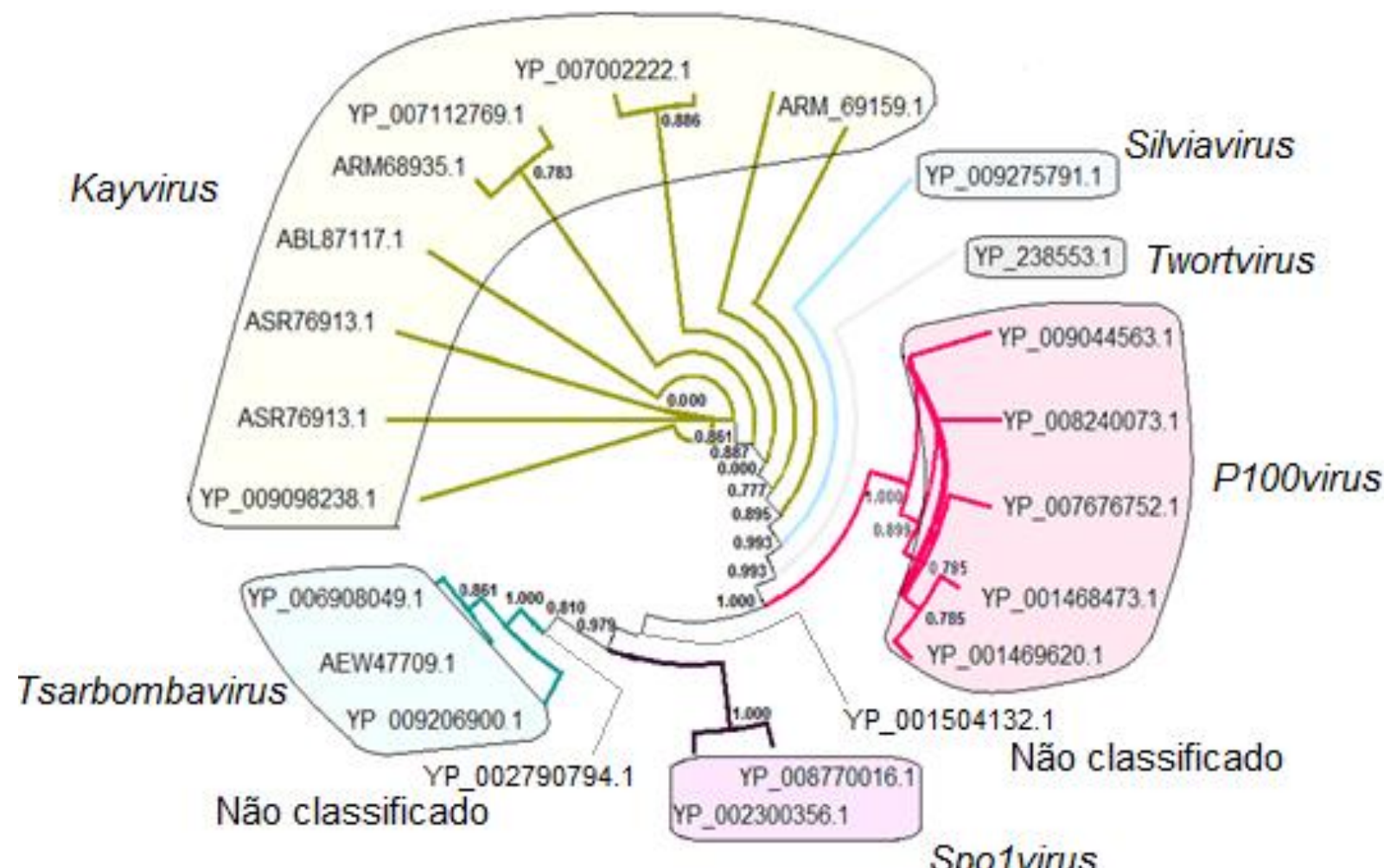

Figura 5 - Árvore filogenética de máxima verossimilhança construída a partir de sequências da proteína da bainha da cauda (Tail Sheath protein) de vírus da subfamília Spounavirinae.

1.5.2 Composição e estrutura das partículas virais

Os vírus pertencentes à subfamília Spounavirinae não são envelopados e possuem uma estrutura do tipo cabeça-cauda (Figura 6). O capsídeo apresenta um diâmetro de 84-94 nm e uma simetria icosaédrica. Esses vírus não apresentam integração com o genoma da bactéria hospedeira, sendo estritamente virulentos e líticos (Barylski, Nowicki \& Goździcka-Józefiak, 2014).

O material genético dos vírus da subfamília Spounavirinae é constituído de um segmento linear de DNA de fita dupla. O vírion possui comprimento de 130-160 kb, uma cauda contrátil com comprimento de 140-219 nm e estrutura globular com seis fibras longas terminais acoplados a seis fibras curtas e uma base dupla (ViralZone - https://viralzone.expasy.org/2777 - Acesso em 10 dez 2018). Os componentes estruturais básicos são conservados entre as espécies da subfamília Spounavirinae e incluem a proteína de capsídeo, proteínas da bainha da cauda, fita de medida (Tmp) e a proteína não estrutural helicase (Habann et al., 2014). Os vírus desta subfamília codificam geralmente entre 190 a 230 proteínas, sendo regulados por operons. Entre as proteínas codificadas por esses vírus, algumas proteínas estruturais e não estruturais 
podem ser utilizadas como possíveis marcadores moleculares para a detecção de sequências pertencentes à subfamília Spounavirinae, destacando-se a proteína da bainha da cauda (tail sheath protein - TSP) e terminase.

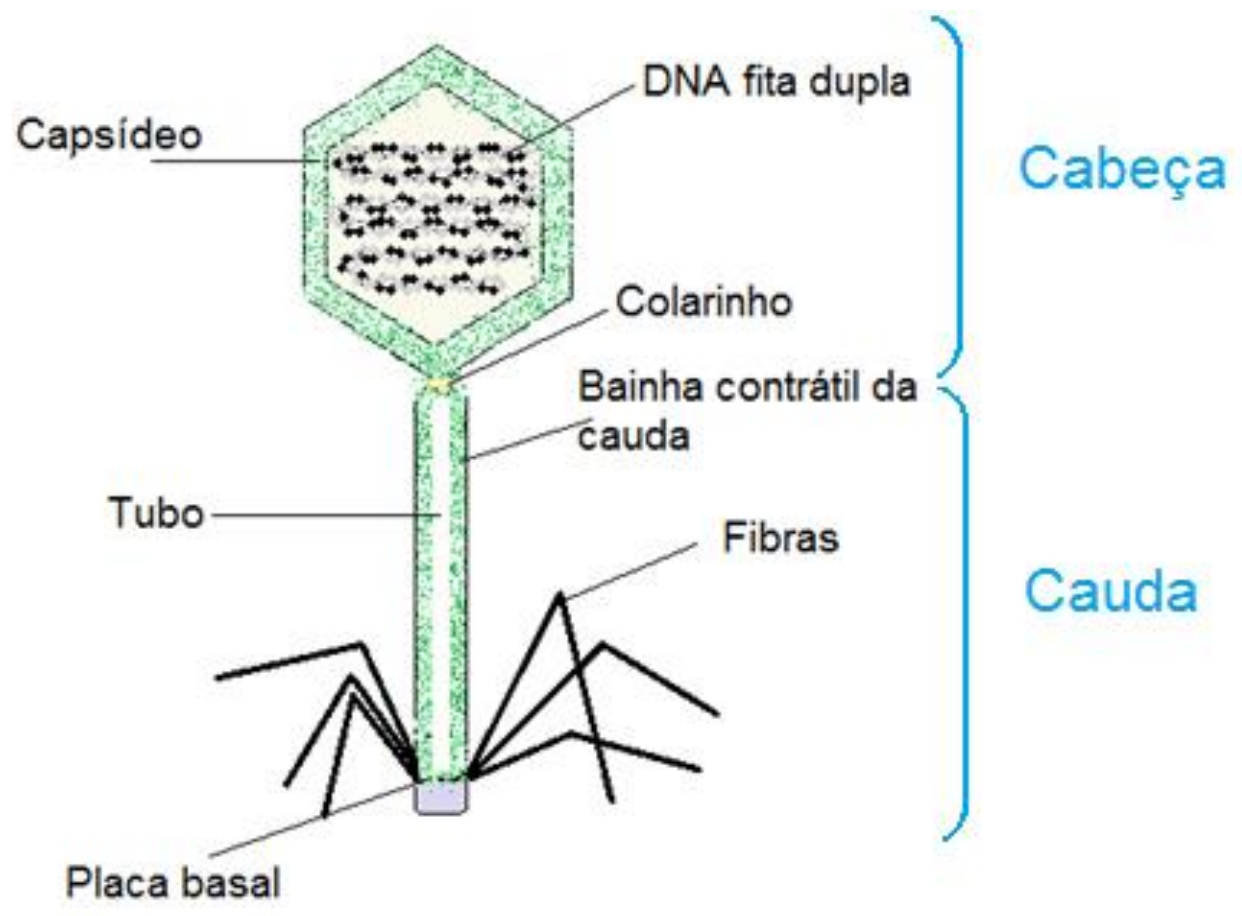

Figura 6 - Estrutura da partícula viral tipicamente encontrada na subfamília Spounavirinae. Modificado a partir de ViralZone (https://viralzone.expasy.org/2777).

\subsubsection{Potencial terapêutico}

Fagos que infectam bactérias e apresentam ciclo lítico, podem ser utilizados como alternativa no tratamento de doenças bacterianas (Khalifa et al., 2015). A aplicação de fagos na terapia de doenças bacterianas comuns ou resistentes pode ter vários benefícios: (1) os fagos possuem alta especificidade relativa, isto é, infectam apenas os hospedeiros que contém em sua superfície proteínas que são responsáveis pelo reconhecimento do vírus e infecção, (2) seu uso causa menos impacto na flora intestinal se comparada ao uso de antibióticos tradicionais que acabam com as bactérias causadoras da doença, mas também com as benéficas que coabitam o intestino, (3) os fagos se replicam rapidamente, podendo eliminar as bactérias patogênicas em um curto período de tempo, (4) desaparecem junto com o patógeno, devido à sua alta 
especificidade, pois se não existem mais hospedeiros para os vírus propagar, acabam sendo eliminados naturalmente do organismo, (5) possuem eficácia contra os biofilmes, que são encontrados em diversos casos de doenças bacterianas que se tornaram resistentes ao uso de antibióticos, e (6) representam um processo natural, diferente dos fármacos sintéticos (Khalifa et al., 2015). Vários vírus da subfamília Spounavirinae que infectam bactérias presentes no homem, já tiveram seu potencial terapêutico comprovado, como Listeria virus P100 (Carlton et al., 2005), Enterococcus virus phiEC24C (Uchiyama et al., 2008), Staphylococcus virus K (O'flaherty et al., 2005) e Staphylococcus virus G1 (Khalifa et al., 2015).

\subsection{Vírus da família Togaviridae}

\subsubsection{Classificação taxonômica e importância}

Os vírus da família Togaviridae são amplamente estudados devido à sua patogenicidade em mamíferos, humanos e marsupiais. São divididos em dois gêneros, conforme descrito pelo ICTV (2018): Rubivirus e Alphavirus. Os vírus da espécie Rubella vírus são os responsáveis pela rubéola (Parkman, Buescher \& Artenstein, 1962; Weller \& Neva, 1962), uma doença que atinge frequentemente crianças e adultos. A propagação da doença ocorre em 42 países que não têm vacinas disponíveis segundo o sítio web da Organização Mundial da Saúde (https://www.who.int/en/news-room/fact-sheets/detail/rubella - Acesso em 13 set 2018). Por outro lado, há 2801 registros da doença no Brasil segundo o boletim semanal do dia três de novembro de

(https://www.paho.org/hq/index.php?option=com_docman\&view=download\&category_slug= boletin-semanal-s-r-2018-9576\&alias=46975-boletin-semanal-de-sarampion-rubeola-44-3-denoviembre-del-2018\&Itemid=270\&lang=es - acesso em $10 \mathrm{dez} 2018$ ), mesmo com a disponibilidade da vacina no país. Os vírus do gênero Alphavirus podem causar diversas patologias em humanos, tais como: artrite, dor de cabeça, erupção cutânea, dor muscular, dor nas juntas e danos musculoesqueléticos. Em equinos, esses vírus podem causar desordem no sistema nervoso central e até a morte (Cui et al., 2018). O vírus mais conhecido deste gênero é o da espécie Chikungunya, que é encontrado em vários países como Brasil, França, Itália, Quênia e Sudão. Entre os sintomas da doença causada por esse vírus, em humanos, são descritos o início súbito de febre, dor de cabeça, dor e edema nas articulações, dor muscular e/ou 
incapacidade de andar (WHO, 2018). A Tabela 5 lista algumas das doenças transmitidas por vírus pertencentes à família Togaviridae e seus respectivos hospedeiros.

Tabela 5 - Características taxonômicas e biológicas de vírus da família Togaviridae.

\begin{tabular}{|c|c|c|c|c|}
\hline Família & Gênero & Espécie & Hospedeiro & Sintomas/Consequência \\
\hline Togaviridae & Rubivirus & Rubella virus & Humanos & $\begin{array}{l}\text { Erupções ou manchas } \\
\text { vermelhas, fadiga, febre, } \\
\text { mal-estar ou perda de } \\
\text { apetite, tosse, dores nos } \\
\text { músculos } 1\end{array}$ \\
\hline Togaviridae & Alphavirus & Chikungunya & Humanos & $\begin{array}{l}\text { Febre, dor nas juntas e } \\
\text { musculares, náuseas, dor } \\
\text { de cabeça, fadiga e erupção } \\
\text { cutânea }^{2}\end{array}$ \\
\hline Togaviridae & Alphavirus & $\begin{array}{l}\text { Venezuelan } \\
\text { equine } \\
\text { encephalitis }\end{array}$ & Equinos & Morte $^{3}$ \\
\hline Togaviridae & Alphavirus & Ross River & Humanos & 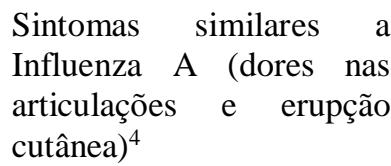 \\
\hline
\end{tabular}

Fonte: ${ }^{1}$ OMS, 2018 (Disponível em: https://www.paho.org/bra/index.php?option=com_content\&view=article\& id=5633:folha-informativa-sarampo\&Itemid=1060); ${ }^{2}$ OMS, 2018 (Disponível em: http://www.who.int/emergen cies/diseases/chikungunya/en/); ${ }^{3}$ WHO, 2018 (Disponível em: http://www.who.int/csr/don/1996_08_06b /en/); ${ }^{4}$ WHO, 2018 (Disponível em: http://www.who.int/iris/handle/10665/222549).

\subsubsection{Composição e estrutura das partículas virais}

Os vírus pertencentes à família Togaviridae possuem um genoma constituído de RNA de fita simples positiva ssRNA (+) com tamanho entre 9,7 a 11,8 kb. Esses vírus possuem envelope em sua estrutura e apresentam uma forma esférica (Figura 7). 


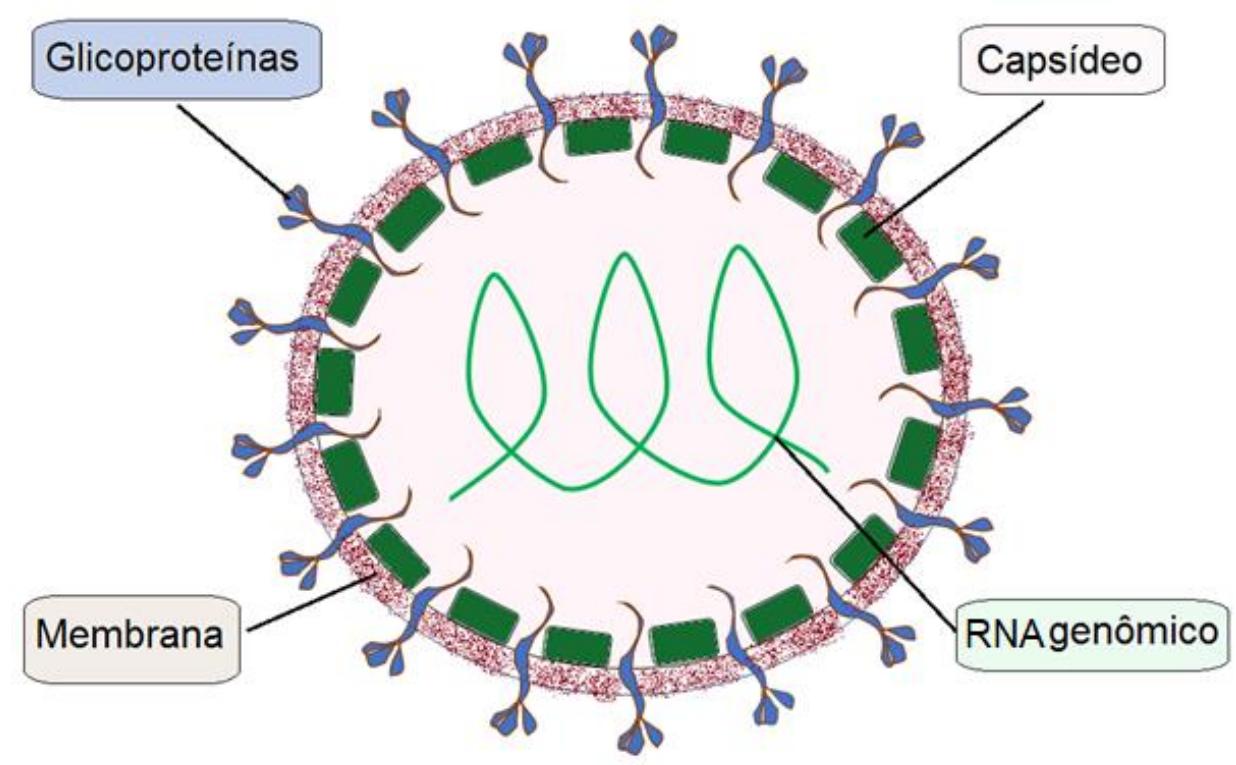

Figura 7 - Estrutura de uma partícula viral tipicamente encontrada em membros da família Togaviridae. Modificado a partir de ViralZone (https://viralzone.expasy.org/3).

Os vírus da família Togaviridae são classificados no grupo 4 da classificação de Baltimore (1971). O genoma é constituído por um único segmento linear que codifica uma poliproteína não estrutural e outra estrutural (Chen et al., 2018), sendo estas as precursoras de várias outras proteínas (Figura 8).

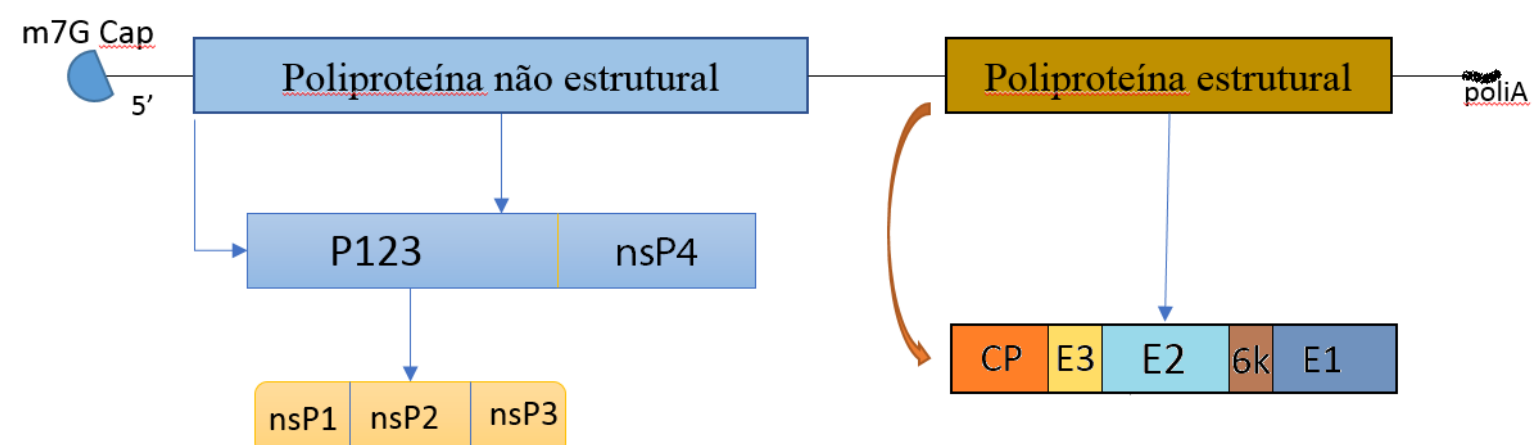

Figura 8 - Diagrama do genoma de ssRNA (+) de Alphavirus, o qual codifica as poliproteínas estrutural e não estrutural. Figura modificada a partir de ViralZone (https://viralzone.expasy.org/625).

Entre as proteínas não estruturais codificadas na família Togaviridae, temos a nsP1 que é uma metiltransferase e guanililtransferase, a nsP2 que é uma helicase e protease, a nsP3 que é uma fosfoproteína e uma hidrolase e a nsP4 que é a RdRp e adenililtransferase que participam do mecanismo de replicação do vírus. As glicoproteínas de superfície E1 e E2, a proteína de 
capsídeo e peptídeos (E3 e o 6k) são as proteínas estruturais encontradas na família Togaviridae (Strauss \& Strauss, 1994). 


\section{Objetivos}

\subsection{Objetivo geral}

O objetivo geral do trabalho é o desenvolvimento e validação de HMMs de perfil para a detecção e classificação de vírus a partir de dados metagenômicos.

\subsection{Objetivos específicos}

- Testar o programa TABAJARA frente a conjuntos de dados de diferentes grupos taxonômicos virais e padronizar um protocolo de construção de HMMs de perfil

- Criar HMMs de perfil com diferentes níveis de especificidade:

- Modelos específicos para cada família viral

- Modelos específicos para cada um dos gêneros de cada família

- Modelos específicos para cada uma das espécies do gênero de uma determinada família

- Validar os modelos obtidos quanto à sua sensibilidade e especificidade

- Testar os modelos contra metagenomas disponíveis na base de dados SRA do NCBI 


\section{Materiais e Métodos}

\subsection{Obtenção de dados}

\subsubsection{Bunyavirales}

Sequências proteicas de nove famílias virais da ordem Bunyavirales foram obtidas a partir do sítio web do National Center for Biotechnology Information (NCBI), utilizando-se a base de dados Identical Protein Groups (IPG - https://www.ncbi.nlm.nih.gov/ipg/). Foram utilizadas sequências de três proteínas: RNA polimerase RNA-dependente (RdRp - segmento L), proteína precursora da glicoproteína de membrana (segmento M) e a nucleoproteína (segmento $\mathrm{S}$ ).

Para a obtenção das sequências, foram usados comandos de busca específicos para cada proteína e grupo taxonômico. Um exemplo de comando para se obter sequências de todas as RdRp da família Hantaviridae segue abaixo:

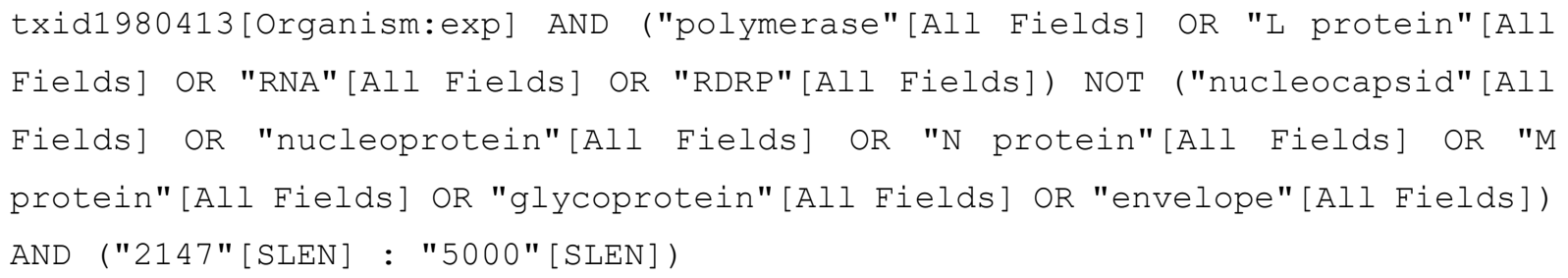

Foram utilizados vários termos de busca para cada proteína, de forma a cobrir as denominações adotadas por diferentes anotações. Assim, para a polimerase os termos utilizados foram "polymerase", "L protein" e "RNA"; para a glicoproteína os termos foram "glycoprotein", "envelope", "precursor" e "M protein"; e para a nucleoproteína usou-se os termos "nucleocapsid", "nucleoprotein" e "N protein". Visando ainda eliminar entradas anotadas incorretamente ou erradamente associadas às proteínas, foram também usados termos negativos. Por exemplo, para a RdRp usou-se os termos negativos "nucleocapsid", nucleoprotein", "N protein", "M protein", "glycoprotein" e "envelope". Finalmente, foram colocadas restrições de tamanho mínimo para evitar a obtenção de sequências parciais e tamanho máximo para evitar sequências diferentes da proteína de interesse. 


\subsubsection{Spounavirinae}

As sequências das proteínas TSP e terminase da subfamília Spounavirinae (família Myoviridae) foram obtidas utilizando-se as bases de dados IPG do NCBI. Para a busca nas bases de dados utilizou-se o nome da proteína de interesse junto com o termo "txID857473" no campo de busca da base IPG. Um exemplo de comando para se obter sequências de todas sequências da TSP da subfamília segue abaixo:

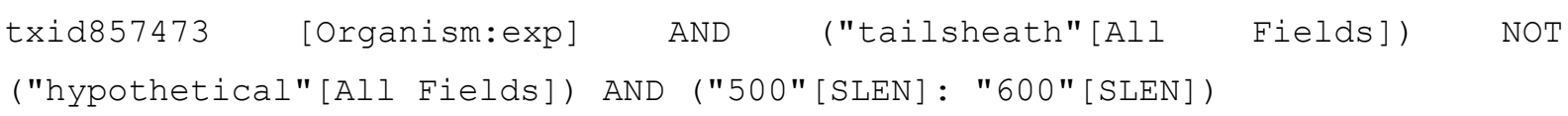

\subsubsection{Togaviridae}

As sequências de poliproteína estrutural e de poliproteína não estrutural da família Togaviridae foram obtidas a partir da base de dados IPG. Um exemplo de comando para obter sequências da poliproteína estrutural segue abaixo:

txid11018[Organism:exp] AND ("structural"[All Fields]) NOT ("non"[All Fields]) AND ("1000"[SLEN]: "1500"[SLEN])

Nesse comando exemplo aplicado para poliproteína estrutural, usou-se o termo "structural", especificando o identificador taxonômico 11018, que corresponde à família Togaviridae. Como termo negativo foi usado “non”, para evitar sequências de poliproteína não estrutural. Também foram colocadas restrições de tamanho mínimo para evitar a obtenção de sequências parciais e de tamanho máximo para evitar sequências diferentes da proteína de interesse.

\subsection{Alinhamento de múltiplas sequências}

Os arquivos em formato FASTA das sequências proteicas de interesse nos três modelos de estudo (Bunyavirales, Spounavirinae e Togaviridae) foram submetidos a alinhamentos de múltiplas das sequências com o programa MUSCLE (Edgar, 2004) utilizando-se parâmetros padrão. 


\subsection{Construção dos HMMs de perfil com o programa TABAJARA}

A construção dos HMMs de perfil foi realizada com o programa TABAJARA. Esse programa, descrito em detalhes no item 1.6, processa os arquivos de alinhamentos de múltiplas sequências, encontra os blocos de alinhamento mais informativos para conservação ou discriminação de grupos de sequências e, finalmente, constrói e valida os modelos. O programa pode ser executado em dois modos: (1) modo conservação para encontrar blocos conservados em todas as sequências do alinhamento e (2) modo discriminação para obter blocos discriminativos entre grupos de sequências. Conforme será apresentado a seguir, os dois modos de operação foram utilizados no presente trabalho. O comando abaixo exemplifica uma típica execução do programa TABAJARA no modo conservação:

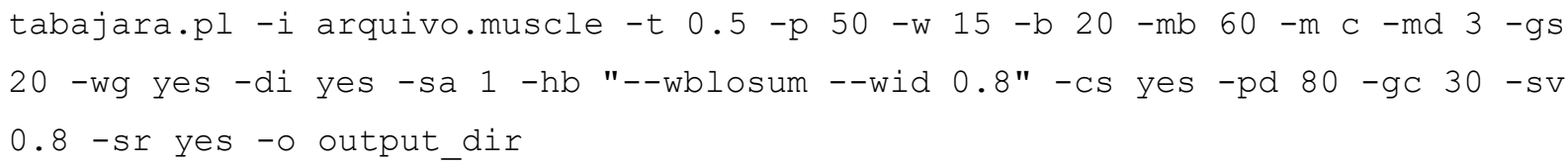

Outro exemplo de comando, para uma execução do modo discriminação segue abaixo:

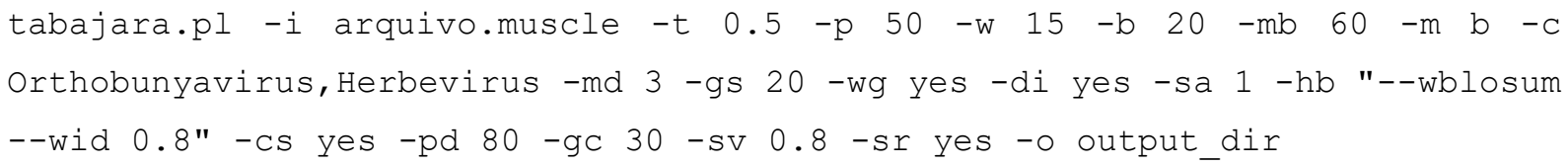

A grande diferença que pode ser notada nesse segundo exemplo de comando é o parâmetro $-m$ b ao invés de $-m$ c, que se refere ao método de execução (discriminação nesse exemplo). O parâmetro -c lista os nomes dos grupos de sequências que deverão ser considerados para discriminação. No exemplo acima, o programa deverá buscar blocos de alinhamento e construir modelos que detectem especificamente sequências dos gêneros Orthobunyavirus ou Herbevirus.

\subsection{Reconstrução filogenética de sequências virais}

Para a reconstrução filogenética de sequências virais, foram utilizados arquivos em formato FASTA contendo os alinhamentos de múltiplas sequências, gerados pelo programa MUSCLE (item 3.2). A análise filogenética foi realizada com o programa FastTree 2.1.9 (Price et al., 2010) utilizando-se o modelo de evolução de aminoácidos WAG e assumindo uma 
taxa variável de evolução entre perfis. Os arquivos dos dendrogramas foram visualizados e editados no programa Dendroscope 3(Huson \& Scornavacca, 2012)

\subsection{Prospecção de vírus em metagenomas}

Os HMMs de perfil foram testados frente a dados metagenômicos disponíveis em bases públicas. Os dados de sequenciamento brutos foram obtidos a partir da base SRA (Sequence Read Archive) do NCBI usando-se o programa fastq-dump (pacote NCBI SRA Toolkit) e os códigos de acesso dos respectivos conjuntos de dados. As Tabelas 6, 7 e 8 listam os conjuntos de dados obtidos para vírus da ordem Bunyavirales, subfamília Spounavirinae e família Togaviridae, respectivamente.

Tabela 6 - Metagenomas obtidos na base $\operatorname{SRA}^{1}$ e utilizados na prospecção de vírus da ordem Bunyavirales.

\begin{tabular}{|c|c|c|c|}
\hline $\begin{array}{l}\text { Código de } \\
\text { acesso }\end{array}$ & Amostra & $\begin{array}{l}\text { Número } \\
\text { de bases }\end{array}$ & Organismo \\
\hline SRR5185734 & $\begin{array}{l}\text { Sequências do genoma correspondente aos } \\
\text { segmentos L, M e S de isolados de } \\
\text { Crimean-Congo Hemorrhagic Fever Virus. }\end{array}$ & $1,9 \mathrm{~Gb}$ & $\begin{array}{l}\text { Crimean-Congo } \\
\text { Hemorrhagic Fever } \\
\text { Virus }\end{array}$ \\
\hline SRR5434405 & $\begin{array}{l}\text { Amostra do vírus a partir da cepa Rift Valley } \\
\text { fever virus rMP12-DNSs } 16 / 198\end{array}$ & $353 \mathrm{Mb}$ & Rift Valley fever virus \\
\hline SRR5630721 & $\begin{array}{l}\text { Rice stripe tenuivirus em insetos da } \\
\text { infraordem Fulgoromorpha }\end{array}$ & $177,3 \mathrm{~Gb}$ & Rice stripe tenuivirus \\
\hline ERR964959 & $\begin{array}{l}\text { Quatro isolados de framboeseiras } \\
\text { apresentando sintomas de infecção por } \\
\text { RLBV }\end{array}$ & $1,4 \mathrm{~Gb}$ & $\begin{array}{l}\text { Raspberry leaf blotch } \\
\text { emaravirus }\end{array}$ \\
\hline SRR5007121 & $\begin{array}{l}\text { Coleção Nacional de Sequenciamento de } \\
\text { Culturas de Vírus Patogênicos (NCPV) }\end{array}$ & $185,6 \mathrm{Mb}$ & $\begin{array}{l}\text { Seoul } \\
\text { orthohantavirus }\end{array}$ \\
\hline SRR5630912 & Amostra de vírus de plantas e viróides & $367,8 \mathrm{Mb}$ & $\begin{array}{l}\text { Chrysanthemum stem } \\
\text { necrosis virus }\end{array}$ \\
\hline SRR3678332 & $\begin{array}{l}\text { Pool de vírus de alta prioridade (inclui } L a \\
\text { Crosse vírus) }\end{array}$ & $1,9 \mathrm{~Gb}$ & La Crosse virus \\
\hline
\end{tabular}

${ }^{1}$ https://www.ncbi.nlm.nih.gov/sra 
Tabela 7 - Metagenomas obtidos na base $\mathrm{SRA}^{1}$ e utilizados na prospecção de vírus da subfamília Spounavirinae e da família Myoviridae.

\begin{tabular}{|c|c|c|c|}
\hline $\begin{array}{l}\text { Código de } \\
\text { acesso }\end{array}$ & Amostra & $\begin{array}{l}\text { Número } \\
\text { de bases }\end{array}$ & Organismo \\
\hline SRR6764339 & Bacteriófagos de Staphylococcus & $98,2 \mathrm{Mb}$ & Staphylococcus phage 812 \\
\hline SRR6814033 & $\begin{array}{l}\text { Isolados a partir de comida do Centro } \\
\text { de Segurança Alimentar e Nutrição } \\
\text { Aplicada }\end{array}$ & $285,5 \mathrm{Mb}$ & Listeria monocytogenes \\
\hline SRR547729 & $\begin{array}{l}\text { Genomas de vírus e fagos que tem } \\
\text { sido isolados no corpo humano }\end{array}$ & $0,96 \mathrm{Mb}$ & $\begin{array}{l}\text { Unclassified bacterial } \\
\text { viruses }\end{array}$ \\
\hline ERR2607591 & Efluentes agrícolas & $6,8 \mathrm{~Gb}$ & Wastewater metagenome \\
\hline SRR1391163 & $\begin{array}{l}\text { Fagos similares a Escherichia coli } \\
\text { O157 }\end{array}$ & $242,7 \mathrm{Mb}$ & $\begin{array}{l}\text { Escherichia coli } 0157 \\
\text { typing phage } 4\end{array}$ \\
\hline DRR039936 & $\begin{array}{l}\text { Fagos isolados a partir dos recifes de } \\
\text { corais Okinawa }\end{array}$ & $5.2 \mathrm{Mb}$ & Vibrio phage $C K B-S 2$ \\
\hline SRR5460626 & $\begin{array}{l}\text { Fagos isolados a partir dos rios } \\
\text { sagrados que atravessam Kathmandu }\end{array}$ & $1,1 \mathrm{~Gb}$ & Unidentified phage \\
\hline
\end{tabular}

${ }^{1}$ https://www.ncbi.nlm.nih.gov/sra

Para se fazer a prospecção utilizou-se o programa HMM-Prospector, desenvolvido pela estudante Liliane Santana Oliveira. Esse programa converte as sequências em formato FASTQ para FASTA, realiza a tradução conceitual em todas as fases de leitura e faz buscas de similaridade entre os HMMs de perfil e as sequências proteicas. Finalmente o programa gera relatórios em formato CSV, os quais podem ser abertos e inspecionados em um programa de planilhas como o MS Excel. Os dados podem ser filtrados determinando-se valores de corte de $e$-value ou de score do alinhamento. 
Tabela 8 - Metagenomas obtidos na base $\mathrm{SRA}^{1}$ e utilizados na prospecção de vírus da família Togaviridae.

\begin{tabular}{|c|c|c|c|}
\hline $\begin{array}{l}\text { Código de } \\
\text { acesso }\end{array}$ & Amostra & $\begin{array}{l}N^{\circ} \text { de } \\
\text { bases }\end{array}$ & Organismo \\
\hline ERR2352333 & Genomas de vírus de RNA do NCPV & $176,4 \mathrm{Mb}$ & Bebaru virus \\
\hline SRR7993746 & $\begin{array}{l}\text { Cepas de CHIKV isoladas a partir de pacientes } \\
\text { no México entre } 2014 \text { e } 2015\end{array}$ & $80,2 \mathrm{Mb}$ & Chikungunya virus \\
\hline SRR7617262 & $\begin{array}{l}\text { Sequenciamento de cerca de } 200 \text { cepas de } \\
\text { CHIKV a partir de pacientes doentes }\end{array}$ & $14 \mathrm{Mb}$ & Chikungunya virus \\
\hline SRR3086409 & Chikungunya Virus 257263 & $2 \mathrm{~Gb}$ & Chikungunya virus \\
\hline SRR3287364 & Eastern Equine Encephalitis Virus & $2.8 \mathrm{~Gb}$ & $\begin{array}{l}\text { Eastern equine } \\
\text { encephalitis virus }\end{array}$ \\
\hline SRR7001118 & $\begin{array}{l}\text { Genomas de EEEV and MADV isolados entre } \\
1971 \text { e } 2012 \text { a partir de mosquitos e cavalos }\end{array}$ & $25,3 \mathrm{Mb}$ & $\begin{array}{l}\text { Eastern equine } \\
\text { encephalitis virus }\end{array}$ \\
\hline SRR7005582 & $\begin{array}{l}\text { Genomas de EEEV and MADV isolados entre } \\
1971 \text { e } 2012 \text { a partir de mosquitos e cavalos }\end{array}$ & $70,1 \mathrm{Mb}$ & $\begin{array}{l}\text { Eastern equine } \\
\text { encephalitis virus }\end{array}$ \\
\hline SRR5007126 & $\begin{array}{l}\text { Sequenciamento de amostra de cultura de vírus } \\
\text { a partir do NCPV }\end{array}$ & $4,4 \mathrm{Mb}$ & Onyong-nyong virus \\
\hline ERR2352309 & Genomas de vírus de RNA do NCPV & $201,5 \mathrm{Mb}$ & Ross River virus \\
\hline SRR038589 & Generic sample from Rubella virus & 7,4 Mb & Rubella virus \\
\hline ERR2352300 & Genomas de vírus de RNA do NCPV & $177,3 \mathrm{Mb}$ & Semliki Forest virus \\
\hline SRR6761645 & Mosquitos infectados com Alphaviruses & $1,2 \mathrm{~Gb}$ & Semliki Forest virus \\
\hline SRR6761647 & Mosquitos infectados com Alphaviruses & $854,3 \mathrm{Mb}$ & Semliki Forest virus \\
\hline ERR2352310 & Sequenciamento do genoma de vírus de RNA & $184 \mathrm{Mb}$ & Sindbis virus \\
\hline SRR5175593 & Sequências de reads brutos de Sindbis virus & $31,9 \mathrm{Mb}$ & Sindbis virus \\
\hline SRR5311238 & Abelhas infectadas com Sindbis virus & $3,4 \mathrm{~Gb}$ & Sindbis virus \\
\hline SRR3218237 & Venezuelan Equine Encephalitis Virus Piura & $1 \mathrm{~Gb}$ & $\begin{array}{l}\text { Venezuelan equine } \\
\text { encephalitis virus }\end{array}$ \\
\hline SRR3218240 & Venezuelan Equine Encephalitis Virus 52/73 & $708,3 \mathrm{Mb}$ & $\begin{array}{l}\text { Venezuelan equine } \\
\text { encephalitis virus }\end{array}$ \\
\hline SRR6026550 & $\begin{array}{l}\text { Pernas e asas de Culex taeniopus infectado com } \\
\text { Venezuelan equine encephalitis virus }\end{array}$ & $1,6 \mathrm{~Gb}$ & $\begin{array}{l}\text { Venezuelan equine } \\
\text { encephalitis virus }\end{array}$ \\
\hline SRR3209214 & Western Equine Encephalitis Virus 98-2435 & $1,3 \mathrm{~Gb}$ & $\begin{array}{l}\text { Western equine } \\
\text { encephalitis virus }\end{array}$ \\
\hline SRR2537259 & Western Equine Encephalitis Virus CHLV31 & $2,4 \mathrm{~Gb}$ & $\begin{array}{l}\text { Western equine } \\
\text { encephalitis virus }\end{array}$ \\
\hline SRR2511847 & Western Equine Encephalitis Virus SAC 74 & $2,3 \mathrm{~Gb}$ & $\begin{array}{l}\text { Western equine } \\
\text { encephalitis virus }\end{array}$ \\
\hline
\end{tabular}

${ }^{1}$ https://www.ncbi.nlm.nih.gov/sra 


\section{Resultados e Discussões}

\subsection{Obtenção de sequências a partir da base de dados IPG}

\subsubsection{Bunyavirales}

Utilizando-se a base de dados IPG, foram obtidos conjuntos de sequências para cada uma das nove famílias da ordem Bunyavirales. Esse procedimento foi feito para as proteínas RNA polimerase RNA-dependente (RdRp - segmento L), proteína precursora das glicoproteínas de membrana (segmento M) e a nucleoproteína (segmento S). A Tabela 12 apresenta o número de sequências obtidas para cada família/gênero de acordo com a proteína. A base de dados IPG foi selecionada por apresentar algumas vantagens em relação à base Protein do NCBI. Primeiramente, a base IPG representa um subconjunto da base Protein no qual as sequências redundantes foram removidas, evitando assim vieses de representação. Além disso, embora não documentado, a base IPG parece ser pelo menos parcialmente curada. Observamos que alguns grupos de sequências da base Protein continham membros muito discrepantes, possivelmente frutos de anotações e/ou atribuições taxonômicas erradas. Essas sequências não estão presentes na base IPG, sugerindo que algum procedimento de eliminação de sequências não relacionadas é executado. Essas características tornam a base IPG ideal para estudos como os desenvolvidos neste projeto.

Com base no número de sequências apresentado na Tabela 9, pode-se observar que gêneros que contém espécies patogênicas para humanos, animais e plantas (Orthohantavirus, Phlebovirus, Orthonairovirus, Emaravirus, Orthotospovirus e Orthobunyavirus) são mais representados do que gêneros que infectam invertebrados. 
Tabela 9 - Sequências obtidas na base de dados IPG $^{1}$ do NCBI de acordo com o grupo taxonômico e as proteínas da ordem Bunyavirales.

\begin{tabular}{|c|c|c|c|c|}
\hline Família & Gênero & $\begin{array}{c}\text { Taxonomy } \\
\text { ID }\end{array}$ & Proteína $^{2}$ & $\begin{array}{c}\mathrm{N}^{0} \text { de sequências } \\
\text { do IPG }\end{array}$ \\
\hline Feraviridae & Orthoferavirus & 1980411 & $\begin{array}{l}\mathrm{P} \\
\mathrm{G} \\
\mathrm{N}\end{array}$ & $\begin{array}{l}3 \\
3 \\
1\end{array}$ \\
\hline Fimoviridae & Emaravirus & 1980412 & $\begin{array}{l}\mathrm{P} \\
\mathrm{G} \\
\mathrm{N}\end{array}$ & $\begin{array}{l}17 \\
21 \\
87\end{array}$ \\
\hline Hantaviridae & Orthohantavirus & 1980413 & $\begin{array}{l}\mathrm{P} \\
\mathrm{G} \\
\mathrm{N}\end{array}$ & $\begin{array}{l}206 \\
444 \\
723\end{array}$ \\
\hline Jonviridae & Orthojonvirus & 1980414 & $\begin{array}{l}\mathrm{P} \\
\mathrm{G} \\
\mathrm{N}\end{array}$ & $\begin{array}{l}3 \\
3 \\
3\end{array}$ \\
\hline Nairoviridae & Orthonairovirus & 1980415 & $\begin{array}{l}\mathrm{P} \\
\mathrm{G} \\
\mathrm{N}\end{array}$ & $\begin{array}{l}159 \\
153 \\
182\end{array}$ \\
\hline \multirow[t]{2}{*}{ Peribunyaviridae } & Herbevirus & 1980533 & $\begin{array}{l}\mathrm{P} \\
\mathrm{G} \\
\mathrm{N}\end{array}$ & $\begin{array}{l}7 \\
7 \\
4\end{array}$ \\
\hline & Orthobunyavirus & 11572 & $\begin{array}{l}\mathrm{P} \\
\mathrm{G} \\
\mathrm{N}\end{array}$ & $\begin{array}{l}313 \\
135 \\
339\end{array}$ \\
\hline Phasmaviridae & Orthophasmavirus & 1980417 & $\begin{array}{l}\mathrm{P} \\
\mathrm{G} \\
\mathrm{N}\end{array}$ & $\begin{array}{l}3 \\
6 \\
2\end{array}$ \\
\hline \multirow[t]{4}{*}{ Phenuiviridae } & Goukovirus & 1980420 & $\begin{array}{l}\mathrm{P} \\
\mathrm{G} \\
\mathrm{N}\end{array}$ & $\begin{array}{l}3 \\
3 \\
5\end{array}$ \\
\hline & Phasivirus & 1980421 & $\begin{array}{l}\mathrm{P} \\
\mathrm{G} \\
\mathrm{N}\end{array}$ & $\begin{array}{l}7 \\
7 \\
5\end{array}$ \\
\hline & Phlebovirus & 11584 & $\begin{array}{l}\mathrm{P} \\
\mathrm{G} \\
\mathrm{N}\end{array}$ & $\begin{array}{l}438 \\
409 \\
236\end{array}$ \\
\hline & Tenuivirus & 12329 & $\begin{array}{l}\mathrm{P} \\
\mathrm{G} \\
\mathrm{N}\end{array}$ & $\begin{array}{l}36 \\
15 \\
54\end{array}$ \\
\hline Tospoviridae & Orthotospovirus & 1980419 & $\begin{array}{l}\mathrm{P} \\
\mathrm{G} \\
\mathrm{N}\end{array}$ & $\begin{array}{c}90 \\
130 \\
866\end{array}$ \\
\hline
\end{tabular}

${ }^{1}$ https://www.ncbi.nlm.nih.gov/ipg; ${ }^{2}$ Proteínas: P - RNA polimerase RNA-dependente; G precursor de glicoproteína; $\mathrm{N}$ - nucleoproteína. 


\subsubsection{Spounavirinae}

A partir das buscas realizadas na base de dados IPG, foram obtidas sequências proteicas da subfamília Spounavirinae e da família Myoviridae. Somente as proteínas TSP e a terminase apresentaram sequências representadas em todos e/ou maioria dos gêneros da subfamília Spounavirinae e foram selecionadas como marcadores (Tabela 10).

Tabela 10 - Conjuntos de sequências da subfamília Spounavirinae obtidas a partir da base de dados IPG ${ }^{1}$.

\begin{tabular}{lcccccc}
\hline \multicolumn{1}{c}{ Proteína } & \multicolumn{7}{c}{ Gêneros } \\
\hline & Kayvirus & Twortvirus & Silviavirus & Spolvirus & Tsarbombavirus & P100 virus \\
\hline TSP & 10 & 1 & 1 & 2 & 3 & 5 \\
Terminase & 8 & 0 & 1 & 1 & 3 & 1 \\
\hline
\end{tabular}

${ }^{1}$ https://www.ncbi.nlm.nih.gov/ipg.

\subsubsection{Togaviridae}

Usando-se o termo de busca "structural polyprotein", foram obtidas a partir da base IPG 1074 sequências, sendo 997 sequências pertencentes ao gênero Alphavirus e 77 sequências do gênero Rubivirus. Com o termo "nonstructural polyprotein", 503 sequências foram obtidas, sendo 460 sequências do gênero Alphavirus (Tabela 11) e 27 sequências do gênero Rubivirus. Com base na Tabela 11, podemos observar que para algumas das espécies do gênero Alphavirus não foram obtidas sequências ou foi obtido um número baixo de sequências devido à baixa representação desses grupos na base de dados IPG. 
Tabela 11 - Sequências obtidas na base de dados IPG $^{1}$ do NCBI para espécies do gênero Alphavirus.

\begin{tabular}{|c|c|c|}
\hline \multirow{2}{*}{ Espécie } & \multicolumn{2}{|c|}{ Poliproteína } \\
\hline & Estrutural & Não estrutural \\
\hline Aura virus & 2 & 1 \\
\hline Barmah Forest virus & 3 & 1 \\
\hline Bebaru virus & 2 & 0 \\
\hline Cabassou virus & 1 & 1 \\
\hline Chikungunya virus & 348 & 261 \\
\hline Eastern equine encephalitis virus & 193 & 18 \\
\hline Eilat virus & 1 & 0 \\
\hline Everglades virus & 1 & 1 \\
\hline Fort Morgan virus & 3 & 1 \\
\hline Getah virus & 23 & 7 \\
\hline Highlands $J$ virus & 12 & 10 \\
\hline Madariaga virus & 26 & 2 \\
\hline Mayaro virus & 32 & 21 \\
\hline Middelburg virus & 5 & 0 \\
\hline Mosso das Pedras virus & 1 & 0 \\
\hline Mucambo virus & 1 & 1 \\
\hline Ndumu virus & 9 & 0 \\
\hline Onyong & 4 & 0 \\
\hline Pixuna virus & 1 & 1 \\
\hline Rio Negro virus & 1 & 1 \\
\hline Ross River virus & 10 & 3 \\
\hline Salmon pancreas disease virus & 10 & 0 \\
\hline Semliki Forest virus & 11 & 5 \\
\hline Sindbis virus & 140 & 59 \\
\hline Southern elephant seal virus & 1 & 0 \\
\hline Trocara virus & 1 & 0 \\
\hline Una virus & 2 & 59 \\
\hline Venezuelan equine encephalitis virus & 119 & 30 \\
\hline Western equine encephalitis virus & 36 & 35 \\
\hline Whataroa virus & 1 & 0 \\
\hline
\end{tabular}

\footnotetext{
${ }^{1}$ https://www.ncbi.nlm.nih.gov/ipg.
} 


\subsection{Construção e validação dos HMMs de perfil}

\subsubsection{Bunyavirales}

Foram construídos com o programa TABAJARA modelos com diferentes níveis de especificidade taxonômica. Assim, usando-se o modo conservação do programa, foram construídos HMMs de perfil conservados para cada uma das famílias da ordem Bunyavirales. Esses modelos são capazes de detectar no mínimo $80 \%$ das sequências do conjunto de treinamento (ver item 1.3) de cada família, incluindo as sequências de todos os gêneros que compõem esta família. Além disso, foram construídos no modo discriminação do TABAJARA, modelos específicos (discriminativos) para cada gênero. Assim, um modelo do gênero Herbevirus, por exemplo, deveria ser capaz de detectar pelo menos $80 \%$ das sequências desse gênero no conjunto de treinamento, mas nenhuma sequência do gênero Orthobunyavirus (ver Figura 9). Finalmente, todos os modelos, conservados ou discriminativos, foram testados quanto à especificidade de família. Desta forma, um modelo conservado para a família Peribunyaviridae, assim como modelos específicos para os gêneros Orthobunyavirus e Herbevirus, por exemplo, não poderiam detectar nenhuma sequência de vírus de qualquer outra família da ordem Buynavirales. Essa validação foi feita de forma automática com um script que executava o programa hmmsearch, usando os cutoff scores respectivos de HMMs de perfil (ver item 1.3), contra o conjunto de todas as sequências da ordem Bunyavirales. Somente modelos com especificidade de família foram selecionados, o que incluía tanto os modelos conservados de cada família, como também aqueles específicos de cada gênero desta família.

No total, foram obtidos 742 HMMs de perfil família-específicos, compreendendo modelos conservados para cada uma das famílias da ordem (Tabela 12) ou discriminativos para cada gênero (quando havia múltiplos gêneros) das respectivas famílias (Tabela 13). É importante ressaltar que o uso de cutoff scores resultou num grande incremento de modelos validados, pois antes da implementação dessa característica, os modelos tinham que apresentar especificidade absoluta (ausência de detecção de sequências do outro grupo), caso contrário eram descartados através de uma decisão do tipo resultado positivo ou negativo. Com o uso dos cutoff scores, caso um modelo detecte múltiplas sequências do outro grupo, mas os escores de similaridade estejam abaixo do corte, o modelo é aceito e pode ser utilizado com alta especificidade. Concluindo, foram obtidos 480 modelos conservados para cada uma das nove 
famílias da ordem Bunyavirales e 262 modelos específicos para cada um dos gêneros das respectivas famílias.

Tabela 12 - HMMs de perfil construídos pelo programa TABAJARA para famílias da ordem Bunyavirales.

\begin{tabular}{|c|c|c|c|}
\hline Família & Proteína $^{1}$ & $\begin{array}{c}\mathrm{N}^{\circ} \text { de modelos } \\
\text { obtidos }\end{array}$ & $\begin{array}{c}N^{\circ} \text { de modelos } \\
\text { família-específicos }\end{array}$ \\
\hline Feraviridae & $\begin{array}{l}\mathrm{P} \\
\mathrm{G} \\
\mathrm{N}\end{array}$ & $\begin{array}{c}41 \\
17 \\
5\end{array}$ & $\begin{array}{c}41 \\
17 \\
5\end{array}$ \\
\hline Fimoviridae & $\begin{array}{l}\mathrm{P} \\
\mathrm{G} \\
\mathrm{N}\end{array}$ & $\begin{array}{c}34 \\
11 \\
5\end{array}$ & $\begin{array}{c}34 \\
11 \\
5\end{array}$ \\
\hline Hantaviridae & $\begin{array}{l}\mathrm{P} \\
\mathrm{G} \\
\mathrm{N}\end{array}$ & $\begin{array}{c}34 \\
16 \\
9\end{array}$ & $\begin{array}{c}34 \\
16 \\
9\end{array}$ \\
\hline Jonviridae & $\begin{array}{l}\mathrm{P} \\
\mathrm{G} \\
\mathrm{N}\end{array}$ & $\begin{array}{c}39 \\
29 \\
7\end{array}$ & $\begin{array}{c}39 \\
29 \\
7\end{array}$ \\
\hline Nairoviridae & $\begin{array}{l}\mathrm{P} \\
\mathrm{G} \\
\mathrm{N}\end{array}$ & $\begin{array}{c}44 \\
17 \\
2\end{array}$ & $\begin{array}{c}44 \\
17 \\
2\end{array}$ \\
\hline Peribunyaviridae & $\begin{array}{l}\mathrm{P} \\
\mathrm{G} \\
\mathrm{N}\end{array}$ & $\begin{array}{c}33 \\
15 \\
5\end{array}$ & $\begin{array}{c}16 \\
10 \\
5\end{array}$ \\
\hline Phasmaviridae & $\begin{array}{l}\mathrm{P} \\
\mathrm{G} \\
\mathrm{N}\end{array}$ & $\begin{array}{c}34 \\
10 \\
7\end{array}$ & $\begin{array}{c}34 \\
10 \\
7\end{array}$ \\
\hline Phenuiviridae & $\begin{array}{l}\mathrm{P} \\
\mathrm{G} \\
\mathrm{N}\end{array}$ & $\begin{array}{c}14 \\
5 \\
0\end{array}$ & $\begin{array}{c}13 \\
4 \\
0\end{array}$ \\
\hline Tospoviridae & $\begin{array}{l}\mathrm{P} \\
\mathrm{G} \\
\mathrm{N}\end{array}$ & $\begin{array}{c}49 \\
16 \\
6\end{array}$ & $\begin{array}{c}49 \\
16 \\
6\end{array}$ \\
\hline
\end{tabular}

${ }^{1}$ Proteína: P - RNA polimerase RNA-dependente; G - precursor de glicoproteína; N nucleoproteína.

A Figura 9 ilustra um sistema de atribuição de cutoff scores para um HMM de perfil específico do gênero Herbevirus. O programa TABAJARA atribuiu um cutoff score de valor 42,16 (quadro à esquerda) e, no processo de validação, realizou uma busca de similaridade desse modelo contra as sequências do conjunto de treinamento da família Peribunyaviridae, que inclui sequências dos gêneros Herbevirus e Orthobunyavirus. Pode-se notar que o escore de alinhamento mais baixo, obtido para sequências do gênero Herbevirus, foi 48,3, enquanto o 
escore mais alto de sequências do gênero Orthobunyavirus foi 17,6, bem inferior ao valor de corte de 42,16. Assim, mesmo o modelo sendo capaz de detectar sequências do outro gênero, ainda pode ser usado com alta especificidade se a busca de similaridade com o programa hmms earch empregar o cutoff score, simplesmente utilizando-se o parâmetro -T 42.16 .

Tabela 13 - HMMs de perfil construídos pelo programa TABAJARA para a discriminação de gêneros de famílias da ordem Bunyavirales.

\begin{tabular}{|c|c|c|c|c|}
\hline Família & Gênero & Proteína $^{1}$ & $\begin{array}{c}\mathbf{N}^{0} \text { de modelos } \\
\text { obtidos }\end{array}$ & $\begin{array}{c}N^{\circ} \text { de modelos } \\
\text { família-específicos }\end{array}$ \\
\hline \multirow[t]{6}{*}{ Peribunyaviridae } & Herbevirus & $\mathrm{P}$ & 41 & 41 \\
\hline & & $\mathrm{G}$ & 12 & 12 \\
\hline & & $\mathrm{N}$ & 4 & 4 \\
\hline & Orthobunyavirus & $\mathrm{P}$ & 40 & 40 \\
\hline & & $\mathrm{G}$ & 24 & 17 \\
\hline & & $\mathrm{N}$ & 5 & 5 \\
\hline \multirow[t]{12}{*}{ Phenuiviridae } & Goukovirus & $\mathrm{P}$ & 21 & 21 \\
\hline & & $\mathrm{G}$ & 11 & 11 \\
\hline & & $\mathrm{N}$ & 2 & 2 \\
\hline & Phasivirus & $\mathrm{P}$ & 30 & 30 \\
\hline & & $\mathrm{G}$ & 16 & 16 \\
\hline & & $\mathrm{N}$ & 2 & 2 \\
\hline & Phlebovirus & $\mathrm{P}$ & 3 & 3 \\
\hline & & G & 6 & 6 \\
\hline & & $\mathrm{N}$ & 0 & 0 \\
\hline & Tenuivirus & $\mathrm{P}$ & 40 & 40 \\
\hline & & $\mathrm{G}$ & 10 & 10 \\
\hline & & $\mathrm{N}$ & 2 & 2 \\
\hline
\end{tabular}

${ }^{1}$ Proteína: $\mathrm{P}$ - RNA polimerase RNA-dependente; $\mathrm{G}$ - precursor de glicoproteína; $\mathrm{N}$ - nucleoproteína.

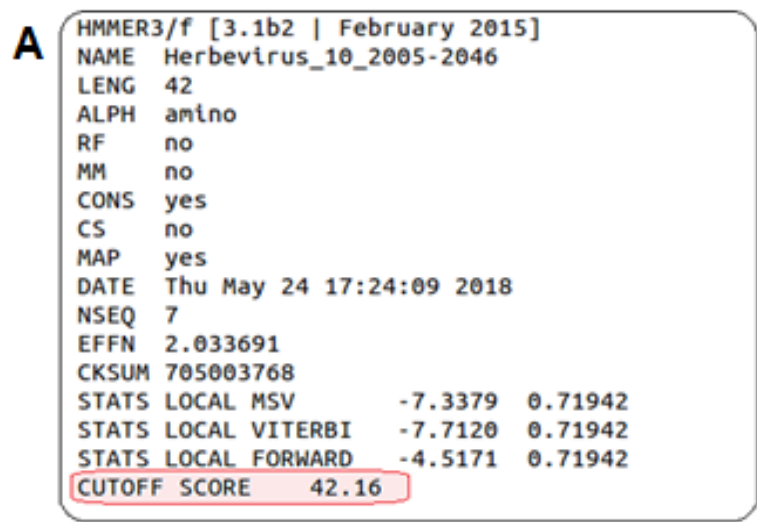

\begin{tabular}{|c|c|c|}
\hline \# target name & E-value & score \\
\hline$\cdots$ & ............ & $\ldots \ldots$ \\
\hline $\begin{array}{l}\text { Herbevirus_AFR34023.1 } \\
\text { n F23/CI } / 2004 \text { F23/CI } / 2004]\end{array}$ & $6 e-29$ & 93.8 \\
\hline Herbevirus_AGX32061.1 & $1.3 e-28$ & 92.7 \\
\hline $\begin{array}{l}\text { Herbevirus_YP_009362026.1 } \\
\text { 04] }\end{array}$ & $2.6 e-28$ & 91.8 \\
\hline Herbevirus_AGX32060.1 & $3.8 e-28$ & 91.3 \\
\hline Herbevirus_AGX32059.1 & $5.7 e-28$ & 90.7 \\
\hline $\begin{array}{l}\text { Herbevirus_YP_009362027.1 } \\
\text { /2008] }\end{array}$ & $1 e-27$ & 89.9 \\
\hline $\begin{array}{l}\text { Herbevirus_YP_009300681.1 } \\
\text { us } 1 \text { QSA02] }\end{array}$ & $9.8 \mathrm{e}-15$ & 48.3 \\
\hline Or thobunyavirus_ATB53298.1 & $3.8 \mathrm{e}-05$ & 17.6 \\
\hline Or thobunyavirus_ATB53299.1 & $3.8 \mathrm{e}-05$ & 17.6 \\
\hline $\begin{array}{l}\text { Or thobunyavirus_AIS74638.1 } \\
\text { 11079] }\end{array}$ & $3.9 e-05$ & 17.6 \\
\hline
\end{tabular}

Figura 9 - Atribuição automática de valores de corte (cutoff scores) (A) pelo programa TABAJARA a partir de resultados de buscas de similaridade com hmmsearch (B), usando-se um HMM de perfil específico para o gênero Herbevirus e um conjunto de treinamento contendo sequências da família Peribunyaviridae (gêneros Orthobunyavirus e Herbevirus). 


\subsubsection{Spounavirinae}

Para o táxon viral Spounavirinae (família Myoviridae), foram construídos modelos conservados para a subfamília e discriminativos para os gêneros, a partir do alinhamento de cada uma das duas proteínas selecionadas, a TSP e a terminase (item 3.1.2). O programa TABAJARA foi utilizado no modo conservação para se obter modelos que detectam todos os gêneros da subfamília e no modo discriminação para se obter modelos específicos de cada um dos gêneros da subfamília Spounavirinae. A Tabela 14 lista a quantidade de HMMs de perfil obtidos para cada uma das proteínas e respectivos taxa virais.

Tabela 14 - HMMs de perfil específicos para a subfamília Spounavirinae, gerados pelo TABAJARA a partir de diferentes proteínas virais.

\begin{tabular}{lcc}
\hline Proteína & Subfamília/Gênero & $\mathbf{N}^{\mathbf{0}}$ de modelos \\
\hline TSP & Spounavirinae & 8 \\
& Kayvirus & 2 \\
Plo0virus & 3 \\
Silviavirus & 0 \\
Spolvirus & 9 \\
Tsarbombavirus & 10 \\
Twortvirus & 1 \\
Terminase & Spounavirinae & 7 \\
& Kayvirus & 3 \\
& Plo0virus & 4 \\
Silviavirus & 0 \\
Spolvirus & 9 \\
Tsarbombavirus & 6 \\
Twortvirus & 0 \\
\hline
\end{tabular}

Pode-se observar que os alinhamentos múltiplos das proteínas TSP e terminase permitiram a construção de 15 modelos conservados para a subfamília Spounavirinae. Obtevese ainda modelos discriminativos para a maioria dos gêneros, com exceção de Silviavirus, um gênero com apenas uma sequência disponível para cada proteína, para o qual o TABAJARA não conseguiu criar modelos discriminativos de gênero. No caso do gênero Twortvirus, o programa conseguiu construir apenas um modelo, apenas para a TSP. Devido à baixa representação de sequências em alguns gêneros da subfamília Spounavirinae (Tabela 10), não se pode afirmar com certeza que os modelos conservados da subfamília seriam capazes de detectar sequências de todos os seus gêneros. Da mesma forma, tampouco pode-se ter certeza que os modelos 
discriminativos sejam de fato absolutamente específicos de seus respectivos gêneros, uma vez uma amostragem maior de sequências poderia potencialmente revelar uma detecção cruzada.

Conforme descrito no item 3.7 de Materiais e Métodos, os 62 HMMs de perfil construídos para a subfamília Spounavirinae foram testados com o programa HMMprospector contra um conjunto de 93 genomas de referência de vírus da subfamília Spounavirinae (Barylski et al., 2018) sendo este conjunto o controle positivo da validação. Conforme podemos ver na Tabela 15, os modelos derivados da terminase, conservados para a subfamília, apresentaram uma sensibilidade de detecção variando 76,3 a 95,7\%. Embora nenhum desses modelos tenha detectado de forma individual $100 \%$ dos genomas de Spounavirinae, usando-se a combinação dos sete modelos, obteve $100 \%$ de detecção (dados não mostrados). No caso da TSP (Tabela 16), a sensibilidade dos modelos conservados variou entre 69,9 a 95,7\% e, assim como no caso da terminase, o uso combinado de todos os modelos conservados resultou na detecção de $100 \%$ dos genomas de Spounavirinae. Os modelos discriminativos da terminase para gêneros apresentaram uma sensibilidade entre 73,3 a 100\%, com exceção de um único modelo do gênero Spolvirus, que detectou apenas um dos dois genomas $(50 \%)$ presentes no conjunto (Tabela 15). No caso dos modelos gênero-específicos da TSP, todos os HMMs de perfil apresentaram uma sensibilidade de detecção de 100\% (Tabela 16).

Visando avaliar o grau de especificidade dos modelos desenvolvidos para a subfamília Spounavirinae, decidiu-se testá-los frente a conjuntos de sequências de vírus pertencentes à família Myoviridae, mas que não são da subfamília Spounavirinae. Para isso, foram obtidas sequências a partir da base IPG do NCBI, usando-se o identificador taxonômico de Myoviridae (txid10662) para as proteínas terminase e TSP (tail sheath protein), como já descrito em buscas anteriores (item 3.1), subtraídas das sequências de Spounavirinae (txid 857473), como exemplificado nos comandos abaixo:

\footnotetext{
txid10662[Organism:exp] NOT txid857473[Organism:exp] AND terminase txid10662[Organism:exp] NOT txid857473[Organism:exp] AND tail sheath
} 
Tabela 15 - Sensibilidade de detecção dos HMMs de perfil derivados da proteína terminase frente a um conjunto padrão de 93 genomas da subfamília Spounavirinae.

\begin{tabular}{|c|c|c|}
\hline HMMs de perfil & $\mathbf{N}^{0}$ de genomas detectados & $\%$ de genomas detectados \\
\hline \multicolumn{3}{|l|}{ Conservados } \\
\hline Conserved_2_141-160 & 71 & 76,3 \\
\hline Conserved_3_185-244 & 88 & 94,6 \\
\hline Conserved_4_279-338 & 87 & 93,5 \\
\hline Conserved_5_347-406 & 86 & 92,5 \\
\hline Conserved_6_450-509 & 88 & 94,6 \\
\hline Conserved_7_510-556 & 89 & 95,7 \\
\hline Conserved_8_558-586 & 83 & 89,2 \\
\hline \multicolumn{3}{|l|}{ Discriminativos } \\
\hline Kayvirus_1_362-394 & 25 & 100,0 \\
\hline Kayvirus_2_234-258 & 25 & 100,0 \\
\hline Kayvirus_3_512-542 & 25 & 100,0 \\
\hline P100virus_1_516-542 & 14 & 93,3 \\
\hline P100virus_2_361-393 & 15 & 100,0 \\
\hline P100virus_3_225-258 & 11 & 73,3 \\
\hline P100virus_4_588-620 & 15 & 100,0 \\
\hline Spo1virus_1_486-529 & 2 & 100,0 \\
\hline Spo1virus_2_437-473 & 2 & 100,0 \\
\hline Spo1virus_3_361-420 & 2 & 100,0 \\
\hline Spo1virus_4_266-289 & 1 & 50,0 \\
\hline Spo1virus_5_191-250 & 2 & 100,0 \\
\hline Spo1virus_6_120-179 & 2 & 100,0 \\
\hline Spo1virus_7_59-86 & 2 & 100,0 \\
\hline Spo1virus_8_20-54 & 2 & 100,0 \\
\hline Spo1virus_9_531-551 & 2 & 100,0 \\
\hline Tsarbombavirus_1_481-539 & 3 & 100,0 \\
\hline Tsarbombavirus_2_401-421 & 3 & 100,0 \\
\hline Tsarbombavirus_3_359-393 & 3 & 100,0 \\
\hline Tsarbombavirus_4_234-253 & 3 & 100,0 \\
\hline Tsarbombavirus_5_1-60 & 3 & 100,0 \\
\hline Tsarbombavirus_6_571-598 & 3 & 100,0 \\
\hline
\end{tabular}


Tabela 16 - Sensibilidade de detecção dos HMMs de perfil derivados da proteína de bainha da cauda (tail sheath) frente a um conjunto padrão de 93 genomas da subfamília Spounavirinae.

\begin{tabular}{ll}
\hline HMMs de perfil & $\begin{array}{c}\mathbf{N}^{\circ} \text { de genomas } \\
\text { detectados }\end{array}$
\end{tabular}$\%$ de genomas detectados

Conservados

Conserved_1_25-84 89

95,7

Conserved_2_109-168

82

88,2

Conserved_3_201-235

81

87,1

Conserved_4_320-379

65

69,9

Conserved_5_380-418

69

74,2

Conserved_6_421-459

95,7

Conserved_7_492-551

89

94,6

Conserved_8_561-609

88

94,6

Discriminativos

Kayvirus_2_276-316

100,0

P100virus_1_132-156

100,0

P100virus_2_361-383

100,0

P100virus_3_393-418

15

100,0

Spo1virus_1_501-559

2

100,0

Spo1virus_2_429-488

2

Spo1virus_3_342-400

2

Spo1virus_4_262-284

2

Spo1virus_5_184-235

2

Spo1virus_6_125-180

2

Spo1virus_7_65-124

2

Spo1virus_8_4-62

2

Spo1virus_9_570-614

2

Tsarbombavirus_10_580-609

3

Tsarbombavirus_1_546-573

Tsarbombavirus_2_474-533

Tsarbombavirus_3_373-406

Tsarbombavirus_4_313-372

Tsarbombavirus_5_184-239

Tsarbombavirus_6_160-182

Tsarbombavirus_7_136-155

Tsarbombavirus_8_86-109

Tsarbombavirus_9_17-45

Twortvirus_1_278-303

100,0

100,0

100,0

100,0

100,0

100,0

100,0

100,0

100,0

3100,0

3100,0

3100,0

3100,0

3100,0

3100,0

3100,0

3100,0

3100,0

1

100,0 
Obteve-se através das buscas acima conjuntos de 1.083 sequências para terminase e 1.240 sequências para a proteína TSP. Todos os HMMs de perfil construídos para a subfamília Spounavirinae (conservados para a subfamília e discriminativos para gêneros) foram então avaliados com o programa HMM-prospector contra esses dois conjuntos de dados, a fim de checar o seu grau de detecção cruzada de outras subfamílias (não Spounavirinae) dentro da família Myoviridae. Os resultados obtidos (Tabelas 17 e 18) parecem sugerir que alguns dos modelos de Spounavirinae, derivados de ambas as proteínas, apresentam detecção cruzada de proteínas de outras subfamílias da família Myoviridae. Por outro lado, uma hipótese alternativa para explicar este resultado seria a possibilidade de estas sequências terem sido incorretamente classificadas em outras subfamílias na base IPG ou, ainda, não terem tido uma classificação taxonômica atribuída em nível de subfamília. Isso explicaria porque uma seleção de sequências baseada em filtros de identificadores taxonômicos pudesse estar incorreta.

Tabela 17 - HMMs de perfil derivados da proteína terminase frente a um conjunto de 1.083 sequências de terminase da família Myoviridae (com exceção de Spounavirinae).

\begin{tabular}{|c|c|}
\hline Modelo & $\begin{array}{l}\mathbf{N}^{\circ} \text { de sequências detectadas em } \\
\text { Myoviridae não-Spounavirinae }\end{array}$ \\
\hline Conserved_2_141-160 & 46 \\
\hline Conserved_3_185-244 & 51 \\
\hline Conserved_4_279-338 & 51 \\
\hline Conserved_5_347-406 & 49 \\
\hline Conserved_6_450-509 & 50 \\
\hline Conserved_7_510-556 & 53 \\
\hline Conserved_8_558-586 & 51 \\
\hline Kayvirus_2_234-258 & 5 \\
\hline Kayvirus_3_512-542 & 5 \\
\hline Spo1virus_2_437-473 & 3 \\
\hline Spo1virus_5_191-250 & 1 \\
\hline Spo1virus_9_531-551 & 3 \\
\hline Tsarbombavirus_2_401-421 & 12 \\
\hline Tsarbombavirus_4_234-253 & 1 \\
\hline Tsarbombavirus_6_571-598 & 12 \\
\hline
\end{tabular}


Tabela 18 - HMMs de perfil derivados da proteína de bainha da cauda (Tail Sheath) frente a um conjunto de 1.240 sequências de bainha da cauda da família Myoviridae (com exceção de Spounavirinae).

\begin{tabular}{lc}
\hline Modelo & $\begin{array}{c}\text { No de sequências detectadas em } \\
\text { Myoviridae não-Spounavirinae }\end{array}$ \\
\hline Conserved_1_25-84 & 55 \\
Conserved_2_109-168 & 42 \\
Conserved_3_201-235 & 42 \\
Conserved_4_320-379 & 29 \\
Conserved_5_380-418 & 58 \\
Conserved_6_421-459 & 57 \\
Conserved_7_492-551 & 58 \\
Conserved_8_561-609 & 54 \\
Tsarbombavirus_1_546-573 & 11 \\
Tsarbombavirus_3_373-406 & 6 \\
Tsarbombavirus_4_313-372 & 5 \\
Tsarbombavirus_5_184-239 & 2 \\
Tsarbombavirus_7_136-155 & 4 \\
Tsarbombavirus_8_86-109 & 5 \\
\hline
\end{tabular}

Com base nos resultados obtidos nessa análise, foi feita então uma curadoria manual. Assim, os códigos de acesso de todas as sequências detectadas (das proteínas terminase e TSP) foram levantados e as redundâncias eliminadas, de forma a se gerar uma lista de códigos de acesso únicos, o que revelou 66 sequências únicas de terminase e 60 de TSP, correspondendo no total a 71 genomas únicos detectados pelos modelos. Usando-se esses códigos, foi feito então um levantamento da classificação taxonômica de cada uma das sequências, para se avaliar se as sequências pertenciam à subfamília Spounavirinae ou a qualquer uma das outras cinco subfamílias da família Myoviridae. Todos os 71 genomas tinham uma classificação taxonômica da família Myoviridae, mas nenhuma das sequencias destes genomas pertenciam a qualquer uma das seis subfamílias. Parte dessas sequências pertenciam a diferentes gêneros órfãos (não incluídos em nenhuma subfamília), como Cp51virus, Wphvirus, B4virus, Sep1virus, Nit1virus e Bastillevirus. As demais sequências apresentavam uma anotação taxonômica de "unclassified Myoviridae". Esses resultados sugerem que as sequências detectadas pelos nossos modelos de Spounavirinae não são necessariamente falso positivas, mas poderiam pertencer à subfamília Spounavirinae e estarem classificadas de forma incompleta ou errônea nas bases de dados do NCBI.

Para elucidar melhor essa possibilidade, decidiu-se realizar uma análise filogenética usando-se essas sequências proteicas, juntamente com sequências de todas as subfamílias e 
gêneros órfãos da família Myoviridae na base IPG para ambas as proteínas, terminase e TSP. Para isso, foi feito um alinhamento de múltiplas sequências como o programa MUSCLE (ver item 3.2), seguido da reconstrução filogenética com o programa FastTree, como descrito no item 3.4. As análises filogenéticas, tanto para a terminase (Figura 10) quanto para a TSP (Figura 11), mostram que todas as sequências detectadas pelos modelos de Spounavirinae, sem exceção, estão presentes em um único clado que contém sequências dessa subfamília. A monofilia observada entre as sequências detectadas pelos modelos, e aquelas sabidamente pertencentes à subfamília Spounavirinae, é uma forte evidência de que os modelos são de fato bastante específicos dessa subfamília. A inclusão no clado de sequências de vírus não classificados da família Myoviridae, bem como de sequências pertencentes a gêneros órfãos, sem subfamília definida, sugere que possivelmente todas essas sequências poderiam ser classificadas como pertencentes à subfamília Spounavirinae. Além disso, todas as sequências disponíveis no IPG para cada um dos gêneros órfãos foram detectadas pelos modelos. Interessantemente, Asare et al. (2015) propuseram um novo gênero dentro da subfamília Spounavirinae, compreendendo um grupo que denominaram Bastille-like, através da utilização das proteínas putative type 1 thymidylate synthase e dihydrofolate reductase como marcadores específicos deste gênero. Segundo a classificação taxonômica do NCBI, estes vírus são pertencentes ao gênero Bastillevirus da família Myoviridae, porém não estão classificados dentro de nenhuma das subfamílias. Nossos resultados (Figuras 10 e 11) corroboram a ideia de que o gênero Bastillevirus deveria ser incluído na subfamília Spounavirinae.

Barylski et al. (2018), usando diferentes abordagens comparativas com dados genômicos, proteômicos e baseadas em genes, concluíram que a subfamília Spounavirinae poderia ser transferida para o nível de família e dividida em pelo menos cinco subfamílias, as quais incluiriam membros de gêneros órfãos e vírus não classificados que pela atual classificação taxonômica estariam dentro da família Myoviridae. Neste caso da subfamília Spounavirinae, ao invés de apresentar seis gêneros (ver Figura 5), teria apenas dois, Cp51virus e Spolvirus, cujos membros infectam hospedeiros do gênero Bacillus. Os cladogramas das Figuras 10 e 11 mostram claramente que os táxons detectados pelos nossos modelos (indicados pelos semicírculos cinzas) estão divididos em dois clados principais, sendo que o clado inferior apresenta um grande número de representantes atualmente classificados como pertencentes à subfamília Spounavirinae (indicados em vermelho). No outro clado, superior, há alguns membros da atual subfamília Spounavirinae, pertencentes ao gênero Tsarbombavirus, e uma 
grande quantidade de táxons pertencente a gêneros órfãos (que não têm subfamília) e vírus não classificados da família Myoviridae.
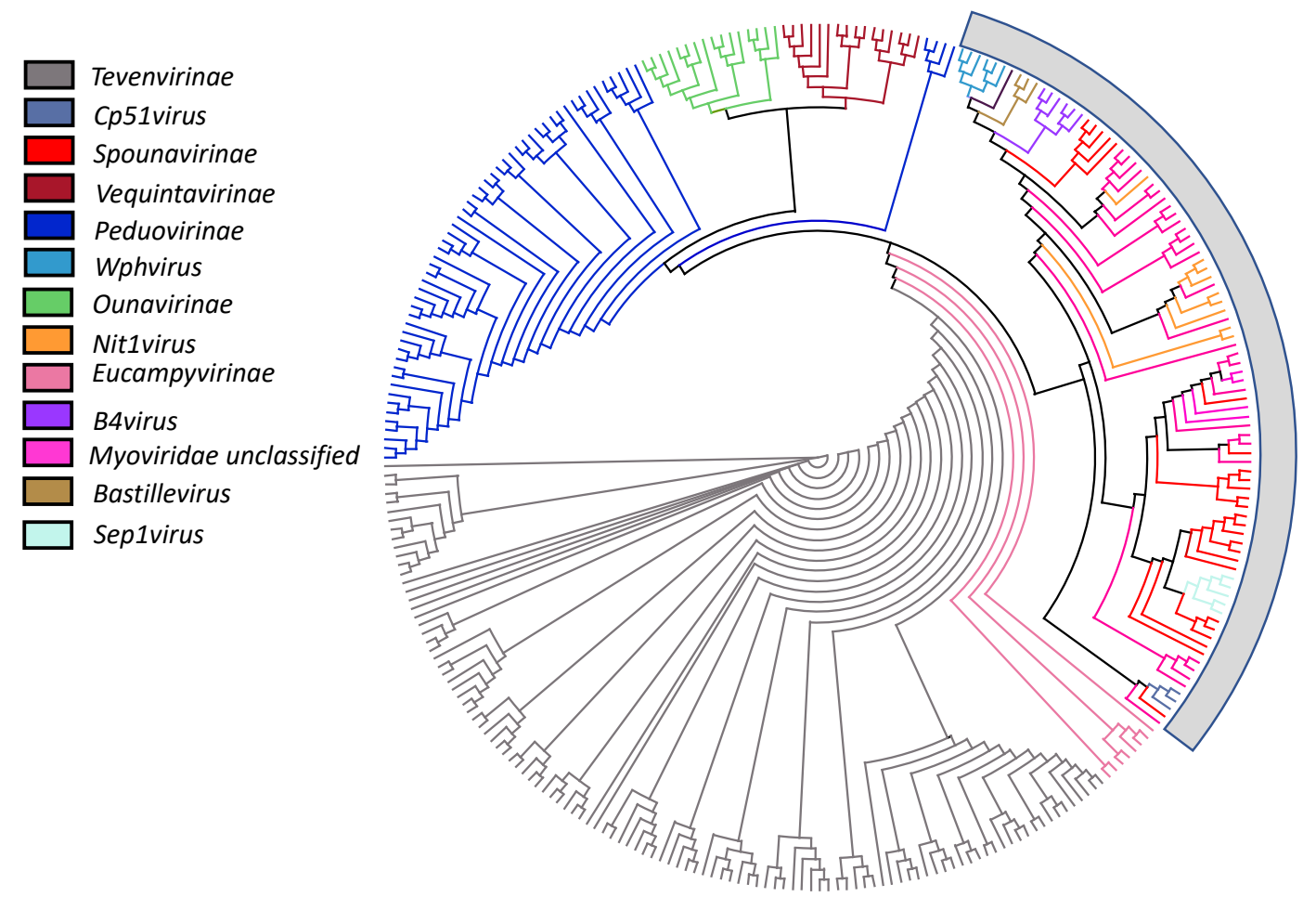

Figura 10 - Cladograma construído a partir das sequências da proteína terminase da família Myoviridae. O semicírculo delimita um clado que contém as sequências detectadas pelos HMMs de perfil da subfamília Spounavirinae.

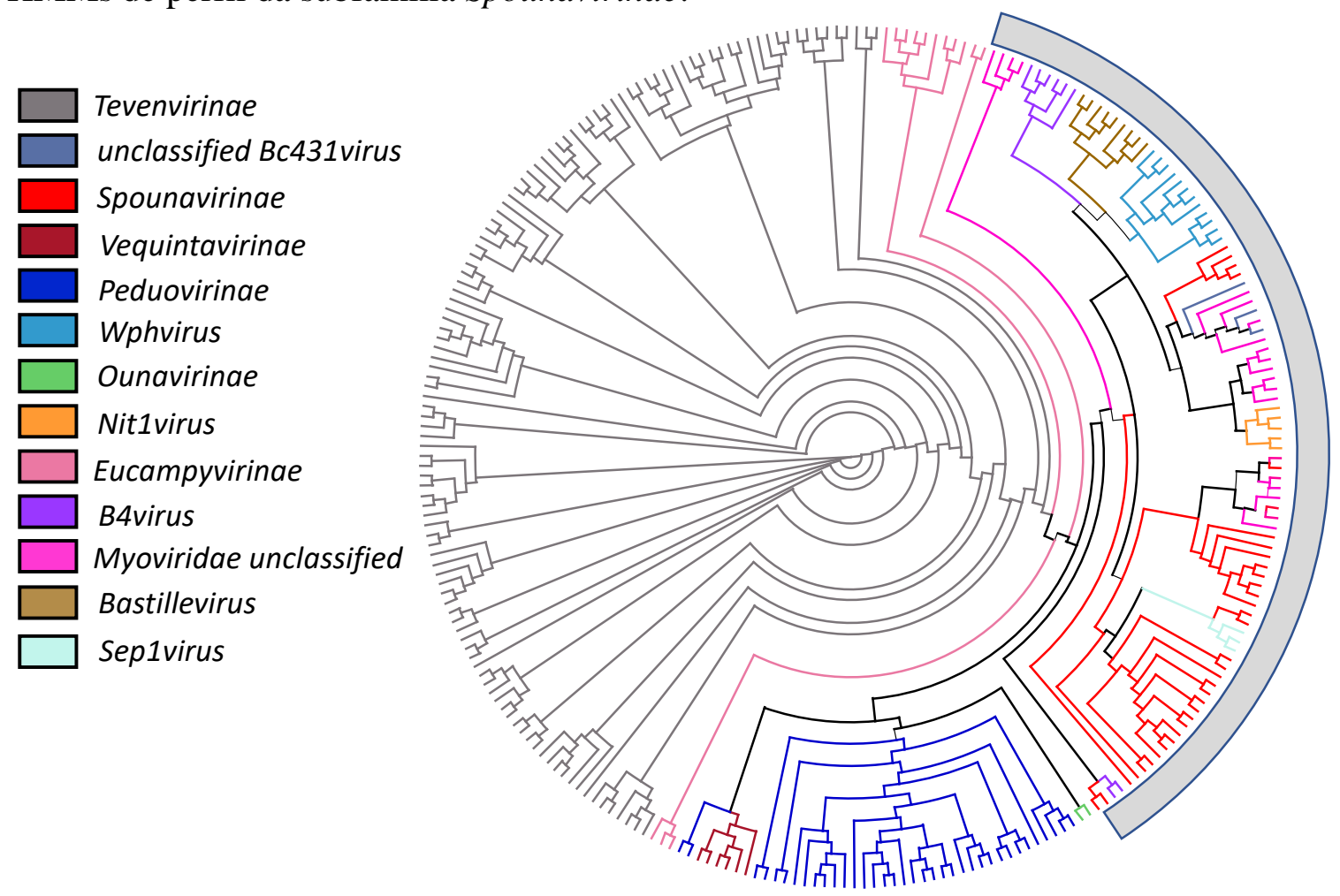

Figura 11 - Cladograma construído a partir das sequências da TSP da família Myoviridae. O semicírculo delimita um clado que contém as sequências detectadas pelos HMMs de perfil da subfamília Spounavirinae. 
Estes vírus de gêneros órfãos, como Wphvirus, Bastillevirus e B4virus, possuem uma similaridade maior com os vírus do gênero Tsarbombavirus (subfamília Spounavirinae) que infectam Bacillus. Barylski et al. (2017) propuseram em seu trabalho uma nova subfamília denominada Bastillevirinae, a qual conteria de forma conjunta os vírus dos gêneros Tsarbombavirus, B4virus, Bastillevirus, Bc431virus, Wphvirus e Nitlvirus. Os autores propuseram ainda que os vírus do gênero órfão Seplvirus deveriam ser classificados no mesmo grupo que aqueles dos gêneros Kayvirus, Twortvirus, Silviavirus e Seplvirus, formando uma nova subfamília denominada Twortvirinae, cujos membros infectam hospedeiros do gênero Staphylococcus.

Concluindo, os modelos conservados para a subfamília Spounavirinae, desenvolvidos em nosso trabalho, foram capazes de detectar 71 genomas de vírus de gêneros órfãos, assim como alguns vírus não classificados, ambos pertencentes à família Myoviridae. As nossas análises filogenéticas dão suporte à classificação desses grupos em conjunto com os atuais membros da família Spounavirinae, a qual, por sua vez, poderia ser dividida em novos grupos taxonômicos, em total concordância às conclusões descritas por Barylski et al. (2018). Portanto, a abordagem desenvolvida em nosso trabalho resultou em HMMs de perfil que podem ser usados como ferramentas de apoio à classificação taxonômica de vírus não classificados, com resultados semelhantes àqueles obtidos por abordagens muito mais elaboradas, como as empregadas por Asare et al. (2015) e Barylski et al. (2018). Finalmente, uma vez definidos novos grupos taxonômicos, como os propostos por Barylski et al. (2018), seria relativamente fácil se desenvolver modelos específicos para cada um desses novos grupos e utilizá-los de forma muito simples para classificar novos vírus em bases de dados públicas.

\subsubsection{Togaviridae}

Semelhantemente aos casos descritos nos itens anteriores, utilizou-se o programa TABAJARA no modo conservação para a construção de HMMs de perfil genéricos para a família Togaviridae e, no modo discriminação, para a obtenção de modelos específicos para os gêneros Alphavirus e Rubivirus (Tabela 19). 
Tabela 19 - HMMs de perfil gerados pelo programa TABAJARA a partir de alinhamentos de múltiplas sequências de poliproteína estrutural e não estrutural de vírus da família Togaviridae. Estão apresentados os resultados para modelos conservados para a família Togaviridae e modelos discriminativos para cada um dos gêneros Alphavirus e Rubivirus.

\begin{tabular}{lcc}
\hline Poliproteína & Grupo taxonômico & $\begin{array}{c}\text { Número de modelos } \\
\text { obtidos }\end{array}$ \\
\hline Estrutural & Togaviridae & 0 \\
& Alphavirus & 20 \\
Não estrutural & Rubivirus & 16 \\
& Togaviridae & 11 \\
& Alphavirus & 30 \\
& Rubivirus & 33 \\
\hline
\end{tabular}

Para a poliproteína estrutural, não foi possível se obter modelos conservados devido à alta divergência entre as sequências dos gêneros Alphavirus e Rubivirus (dados não mostrados), o que impediu o TABAJARA de encontrar blocos de alinhamento conservados entre todas as sequências da família Togaviridae. No caso da poliproteína não estrutural, as sequências são um pouco menos divergentes e isso pode explicar porque o TABAJARA conseguiu encontrar onze blocos que resultaram em modelos conservados capazes de detectar sequências de ambos os gêneros. Por outro lado, as sequências de cada gênero são bastante conservadas e o TABAJARA conseguiu desenvolver modelos discriminativos para ambos os gêneros, tanto para a poliproteína estrutural quanto para a não estrutural. Além dos modelos conservados para a família Togaviridae e discriminativos para os gêneros Alphavirus e Rubivirus, decidimos também construir HMMs de perfil para níveis taxonômicos inferiores, específicos de algumas espécies e/ou clados do gênero Alphavirus, o qual contém vírus de grande relevância para humanos como o Chikungunya, assim como para animais.

O programa TABAJARA só consegue construir modelos discriminativos a partir de um grau mínimo de divergência entre grupos. No caso de várias espécies do gênero Alphavirus, foi possível se obter modelos específicos (dados não mostrados). Contudo, em outros casos, não foi possível construir modelos discriminativos, como entre os vírus Chikungunya e Onyong, assim como entre o Eastern equine encephalitis virus e o Madariaga virus. Assim, decidimos, em uma primeira etapa, realizar uma reconstrução filogenética das sequências do gênero Alphavirus, usando alinhamentos de múltiplas sequências das poliproteínas estruturais (Figura 12) e não estruturais (Figura 13). A partir dessas árvores, foram arbitrariamente selecionados grupos de sequências representando clados ou, ainda, sequências individuais, de acordo com a 
topologia das mesmas. Os vírus de cada grupo estão listados na Tabela 20 e os grupos selecionados estão marcados nos quadros coloridos das árvores (Figuras 12 e 13).

Tabela 20 - Grupos de vírus selecionados a partir de dados filogenéticos (Figuras 12 e 13) para a construção de HMMs de perfil.

\begin{tabular}{cl}
\hline Grupo / Proteína & Espécie do vírus \\
\hline Poliproteína estrutural & \\
Grupo 1 & Chikungunya virus e Onyong \\
Grupo 2 & $\begin{array}{l}\text { Trocara virus, Aura virus, Eilat virus, Whataroa virus, Sindbis virus, } \\
\text { vort Morgan virus, Highlands } J \text { virus e Western equine encephalitis }\end{array}$ \\
Grupo 3 & Madariaga virus e Eastern equine encephalitis virus \\
Grupo 4 & $\begin{array}{l}\text { Everglades virus, Venezuelan equine encephalitis virus, Rio Negro } \\
\text { virus, Mucambo virus, Tonate virus, Pixuna virus, Mosso das Pedras }\end{array}$ \\
e Cabassou virus \\
Grupo 5 & Middelburg virus, Getah virus, Ross River virus, Semliki Forest virus \\
Grupo 6 & Nayaro virus \\
Grupo 7 & Bdumu virus \\
Grupo 8 & Southern elephant seal virus \\
Grupo 9 & Salmon pancreas disease virus \\
Poliproteína não estrutural & \\
Grupo 1 & Chikungunya virus \\
Grupo 2 & Barmah Forest virus \\
Grupo 3 & Rio Negro virus, Cabassou virus, Mucambo virus, Venezuelan equine \\
encephalitis virus, Pixuna virus e Everglades virus \\
Grupo 4 & Fort Morgan virus, Western equine encephalitis virus, Highlands J \\
Grupo 5 & Sirus, Madariaga virus e Eastern equine encephalitis virus \\
Grupo 6 & Getah virus, Ross River virus, Semliki Forest virus e Mayaro virus \\
\hline
\end{tabular}




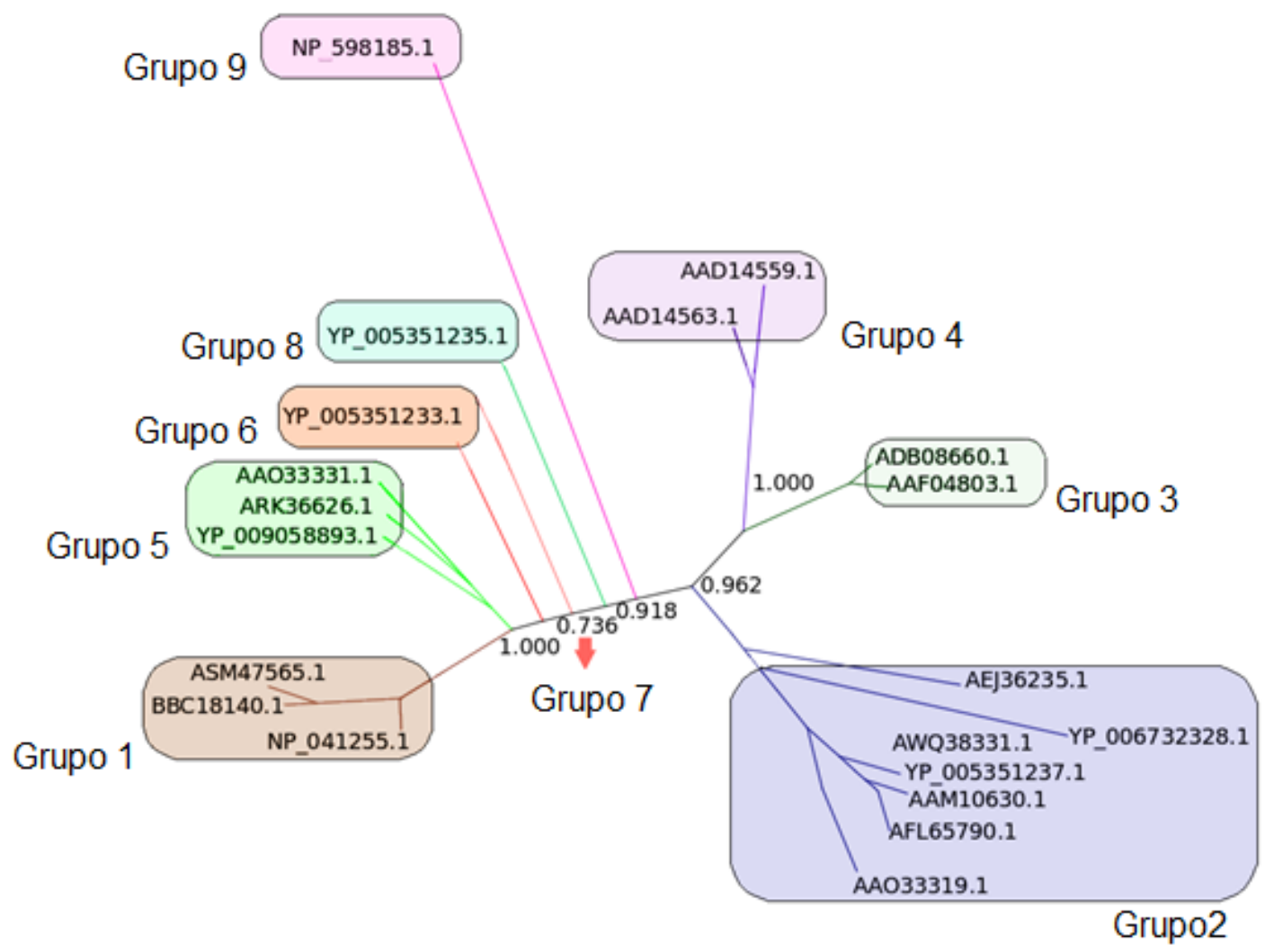

Figura 12 - Árvore filogenética de sequências de poliproteína estrutural de vírus do gênero Alphavirus. Os quadros coloridos indicam os grupos de taxa selecionados arbitrariamente para a construção de HMMs de perfil.

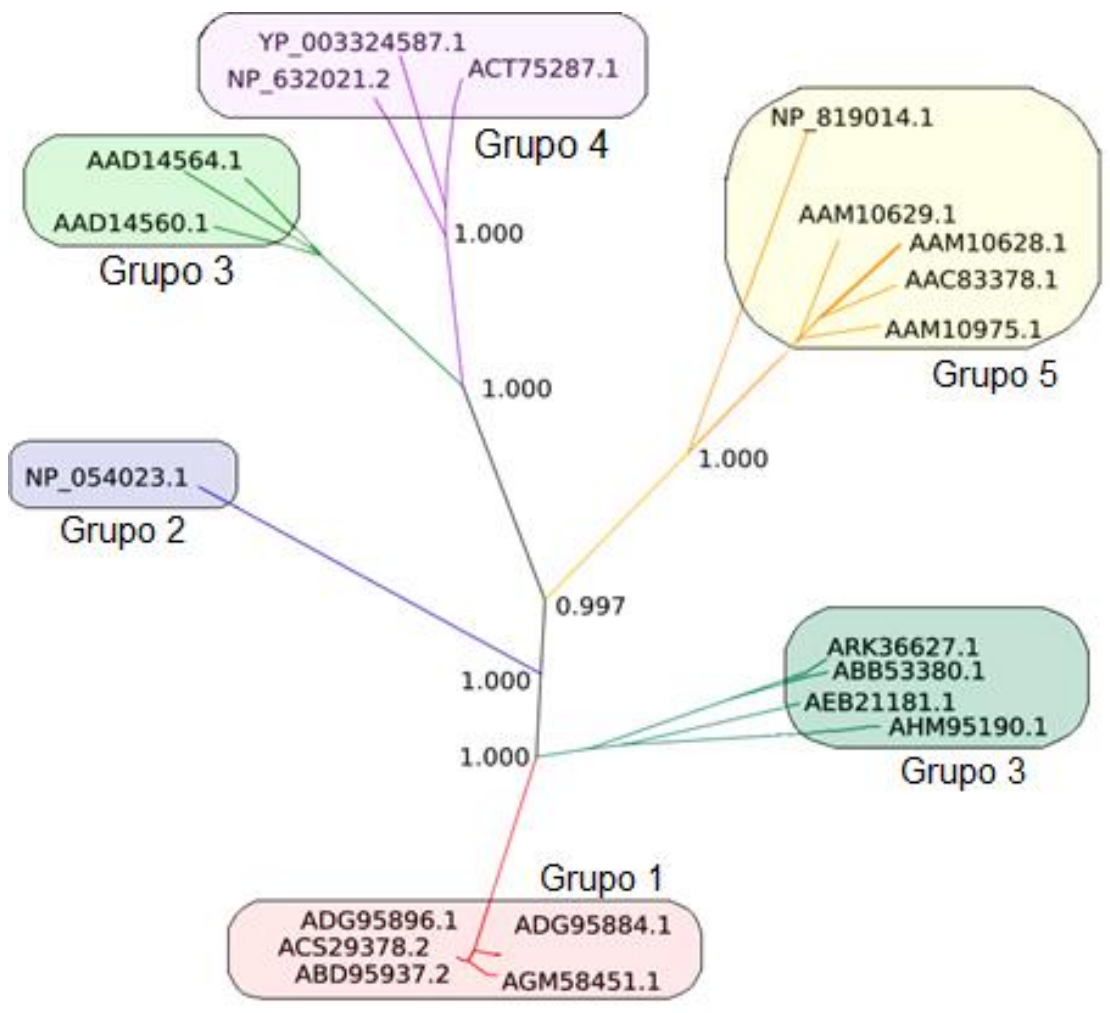

Figura 13 - Árvore filogenética de sequências de poliproteína não estrutural de vírus do gênero Alphavirus. Os quadros coloridos indicam os grupos de taxa selecionados arbitrariamente para a construção de HMMs de perfil. 
Podemos observar na Tabela 20 que vários dos grupos selecionados contêm mais de uma espécie e, em alguns casos, até mesmo oito espécies distintas. Na etapa de construção de modelos específicos para as espécies do gênero Alphavirus, após a seleção manual dos grupos de sequências, com base nas árvores filogenéticas, foram construídos modelos para cada grupo. A Tabela 18 lista a quantidade de modelos obtida para cada grupo de sequências, de acordo com a poliproteína utilizada. Ao final, foram obtidos 11 modelos conservados para a família Togaviridae, 50 modelos específicos de Alphavirus, 49 modelos específicos de Rubivirus (Tabela 19) e 188 modelos para grupos específicos dentro do gênero Alphavirus (Tabela 21).

Tabela 21 - HMMs de perfil gerados pelo programa TABAJARA a partir de alinhamentos de múltiplas sequências de poliproteína estrutural e não estrutural de vírus do gênero Alphavirus. Estão apresentados os resultados para modelos discriminativos para cada um dos clusters do gênero Alphavirus (ver Figuras 12 e 13).

\begin{tabular}{ccccccc}
\hline \multirow{2}{*}{ Grupo } & \multicolumn{2}{c}{ Poliproteína estrutural } & & \multicolumn{2}{c}{ Poliproteína não estrutural } \\
\cline { 2 - 3 } \cline { 5 - 6 } & $\begin{array}{c}\mathbf{N}^{\mathbf{0}} \text { de modelos } \\
\text { construídos }\end{array}$ & $\begin{array}{c}\mathbf{N}^{\mathbf{0}} \text { de modelos } \\
\text { validados }\end{array}$ & & $\begin{array}{c}\mathbf{N}^{\mathbf{0}} \text { de modelos } \\
\text { construídos }\end{array}$ & $\begin{array}{c}\mathbf{N}^{\mathbf{0}} \text { de modelos } \\
\text { validados }\end{array}$ \\
\hline 1 & 24 & 8 & & 6 & 6 \\
2 & 19 & 5 & & 13 & 13 \\
3 & 23 & 17 & & 39 & 22 \\
4 & 23 & 17 & & 38 & 17 \\
5 & 21 & 2 & & 34 & - \\
6 & 7 & 7 & & 29 & - \\
7 & 13 & 13 & & - & - \\
8 & 13 & 13 & & - & - \\
9 & 22 & 22 & & - & - \\
\hline
\end{tabular}

\subsection{Prospecção de vírus em metagenomas}

Uma vez desenvolvidos os HMMs de perfil, decidiu-se testá-los frente a dados metagenômicos reais, para avaliar sua capacidade de detecção e classificação taxonômica de leituras. Esses testes envolveram os três grupos de vírus para os quais foram desenvolvidos modelos: Bunyavirales, Spounavirinae e Togaviridae. 


\subsubsection{Bunyavirales}

Para o teste dos modelos, foram obtidas sete amostras metagenômicas disponíveis na base de dados SRA (Tabela 6), sabidamente positivas para vírus das famílias Hantaviridae, Phenuiviridae, Peribunyaviridae, Fimoviridae, Tospoviridae e Nairoviridae. Essas amostras foram selecionadas na base de dados usando-se termos de busca compostos pelos seus respectivos nomes taxonômicos. Para a prospecção dos vírus, foram usados todos os modelos construídos para as famílias da ordem Bunyavirales. As buscas de similaridade foram realizadas utilizando-se o programa HMM-prospector (ver item 3.6) com o uso do cutoff score específico de cada modelo. A Tabela 22 mostra um exemplo de saída do programa, na qual se observa que somente modelos derivados da família Nairoviridae foram capazes de detectar leituras positivas na amostra metagenômica de código SRR5185734. Todos os resultados gerados pelo HMM-prospector para as demais amostras metagenômicas (dados não mostrados) apresentaram resultados similares, com os modelos mostrando alta especificidade para as proteínas virais de seus respectivos grupos taxonômicos. Em alguns casos, foi observada a detecção cruzada de modelos específicos para uma família em amostras sabidamente positivas para outra família da ordem Bunyavirales. Entretanto, o número de leituras detectadas foi extremamente baixo, muito inferior ao número típico de leituras detectadas pelos modelos da própria família. Um outro aspecto importante é que no caso da detecção correta (verdadeiros positivos), múltiplos modelos específicos da família detectam um alto número de leituras na amostra positiva (Tabela 22). Por outro lado, nos casos falsos positivos, alguns poucos modelos detectam um baixo número de leituras nas amostras de outras famílias. Assim, cada conjunto de modelos família-específicos acaba funcionando como um sistema auto validador. 
Tabela 22 - Resultados gerados pelo programa HMM-prospector para uma prospecção com HMMs de perfil da ordem Bunyavirales contra o metagenoma SRR5185734.

\begin{tabular}{|c|c|}
\hline Modelos positivos & $\begin{array}{c}\text { Número de leituras detectados } \\
\text { pelo modelo }\end{array}$ \\
\hline Nairoviridae_gly_10_1720-1779* & 102289 \\
\hline Nairoviridae_gly_11_1781-1840 & 59473 \\
\hline Nairoviridae_gly_12_1927-1986 & 73317 \\
\hline Nairoviridae_gly_13_1993-2052 & 78425 \\
\hline Nairoviridae_gly_14_2155-2209 & 77638 \\
\hline Nairoviridae_gly_1_820-843 & 55485 \\
\hline Nairoviridae_gly_2_911-970 & 67921 \\
\hline Nairoviridae_gly_3_988-1041 & 63762 \\
\hline Nairoviridae_gly_4_1067-1126 & 109684 \\
\hline Nairoviridae_gly_5_1169-1191 & 95213 \\
\hline Nairoviridae_gly_6_1193-1252 & 72694 \\
\hline Nairoviridae_gly_7_1329-1388 & 93886 \\
\hline Nairoviridae_gly_8_1552-1591 & 103677 \\
\hline Nairoviridae_gly_9_1642-1701 & 77699 \\
\hline Nairoviridae_nucl_1_3245-3267 & 183753 \\
\hline Nairoviridae_nucl_2_3420-3445 & 144543 \\
\hline Nairoviridae_pol_10_2202-2261 & 29007 \\
\hline Nairoviridae_pol_11_2273-2310 & 25537 \\
\hline Nairoviridae_pol_12_2459-2518 & 17334 \\
\hline Nairoviridae_pol_13_2701-2760 & 21644 \\
\hline Nairoviridae_pol_14_2809-2868 & 27350 \\
\hline Nairoviridae_pol_15_3000-3059 & 198654 \\
\hline Nairoviridae_pol_16_3268-3327 & 122238 \\
\hline Nairoviridae_pol_17_3367-3426 & 71116 \\
\hline Nairoviridae_pol_18_3588-3647 & 85057 \\
\hline Nairoviridae_pol_19_3760-3797 & 83933 \\
\hline Nairoviridae_pol_1_37-64 & 64791 \\
\hline Nairoviridae_pol_20_3985-4044 & 76695 \\
\hline Nairoviridae_pol_21_4136-4195 & 68962 \\
\hline Nairoviridae_pol_22_4273-4332 & 67115 \\
\hline Nairoviridae_pol_23_4373-4432 & 85711 \\
\hline Nairoviridae_pol_24_4441-4500 & 71248 \\
\hline Nairoviridae_pol_25_4559-4604 & 86558 \\
\hline Nairoviridae_pol_26_4628-4654 & 72437 \\
\hline Nairoviridae_pol_27_4657-4676 & 85418 \\
\hline Nairoviridae_pol_28_4737-4770 & 82300 \\
\hline Nairoviridae_pol_29_4800-4822 & 98264 \\
\hline Nairoviridae_pol_2_227-249 & 31448 \\
\hline Nairoviridae_pol_3_892-951 & 28141 \\
\hline Nairoviridae_pol_4_997-1019 & 25908 \\
\hline Nairoviridae_pol_5_1024-1065 & 23779 \\
\hline Nairoviridae_pol_6_1246-1305 & 24406 \\
\hline Nairoviridae_pol_7_1717-1776 & 31687 \\
\hline Nairoviridae_pol_8_1947-2005 & 41271 \\
\hline Nairoviridae_pol_9_2052-2111 & 26838 \\
\hline
\end{tabular}

* A nomenclatura de cada modelo inclui o nome taxonômico, proteína de origem (nucl. - nucleoproteína; pol polimerase; gly - glicoproteína), número do modelo e coordenadas do bloco de alinhamento utilizado para sua construção. 


\subsubsection{Spounavirinae}

Os modelos aprovados que passaram por todas as etapas de validação foram utilizados na prospecção de vírus em metagenomas disponíveis na base de dados SRA. Os metagenomas utilizados (Tabela 7) foram encontrados na base de dados através do uso dos termos "Spounavirinae" e "unclassified Myoviridae". Esta análise teve como objetivo verificar se os modelos conseguiam detectar sequências de vírus Spounavirinae em metagenomas sabidamente positivos e novos vírus dessa subfamília, não identificados previamente. Foram utilizados os 62 modelos específicos construídos para a subfamília. Como conjuntos de dados, foram utilizados 196 metagenomas obtidos da base de dados SRA do NCBI, contendo em sua maioria sequências de fagos não classificados da família Myoviridae. Apenas um dos metagenomas (SRR6764339) era sabidamente positivo para vírus da subfamília Spounavirinae (Tabela 23), sendo o Staphylococcus phage 812, pertencente ao gênero Kayvirus.

Tabela 23 - Resultados gerados pelo programa HMM-prospector para uma prospecção com HMMs de perfil da subfamília Spounavirinae contra o metagenoma SRR6764339.

\begin{tabular}{lc}
\hline Modelos positivos & $\begin{array}{c}\text { Número de leituras detectados } \\
\text { pelo modelo }\end{array}$ \\
\hline Spounavirinae_tail_sheath_1_25-84* & 458 \\
Spounavirinae_tail_sheath_2_109-168 & 494 \\
Spounavirinae_tail_sheath_3_201-235 & 555 \\
Spounavirinae_tail_sheath_4_320-379 & 447 \\
Spounavirinae_tail_sheath_5_380-418 & 520 \\
Spounavirinae_tail_sheath_6_421-459 & 558 \\
Spounavirinae_tail_sheath_7_492-551 & 524 \\
Spounavirinae_tail_sheath_8_561-609 & 534 \\
Spounavirinae_terminase_2_141-160 & 516 \\
Spounavirinae_terminase_3_185-244 & 386 \\
Spounavirinae_terminase_4_279-338 & 462 \\
Spounavirinae_terminase_5_347-406 & 375 \\
Spounavirinae_terminase_6_450-509 & 489 \\
Spounavirinae_terminase_7_510-556 & 667 \\
Spounavirinae_terminase_8_558-586 & 630 \\
Kayvirus_tail_sheath_1_131-152 & 480 \\
Kayvirus_tail_sheath_2_276-316 & 379 \\
Kayvirus_terminase_1_362-394 & 450 \\
Kayvirus_terminase_2_234-258 & 454 \\
Kayvirus_terminase_3_512-542 & 459 \\
\hline
\end{tabular}

\footnotetext{
* A nomenclatura de cada modelo inclui o nome taxonômico, proteína de origem, número do modelo e coordenadas do bloco de alinhamento utilizado para sua construção.
} 
Podemos verificar para a amostra metagenômica SRR6764339 que todos os modelos construídos para a subfamília Spounavirinae e para o gênero Kayvirus detectaram um alto número de leituras positivas. Esse resultado demonstra a viabilidade de se utilizar HMMs de perfil para a detecção e classificação de sequências de vírus da subfamília Spounavirinae em amostras metagenômicas. Além disso, o uso combinado de múltiplos modelos derivados de mais de uma proteína pode aumentar a sensibilidade da detecção.

Os demais metagenomas que continham amostras de fagos não classificados da família Myoviridae não apresentaram similaridade significativa contra os modelos da subfamília Spounavirinae. Isso sugere que essas amostras são negativas para vírus da subfamília Spounavirinae ou, alternativamente, que possíveis vírus presentes sejam filogeneticamente distantes das sequências utilizadas para a construção dos modelos, reduzindo a possibilidade de sua detecção.

\subsubsection{Togaviridae}

Os modelos construídos para a família Togaviridae foram testados contra metagenomas obtidos a partir da base de dados SRA do NCBI (Tabela 8). Foram testados no total 298 modelos construídos para a família Togaviridae frente a 22 metagenomas da base SRA do NCBI, derivados de uma grande variedade de amostras, incluindo culturas de vírus isolados e amostras de pacientes humanos e de artrópodes. Todos os metagenomas utilizados eram sabidamente positivos para vírus da família Togaviridae e, de fato, essa condição foi confirmada pelas buscas de similaridade com os modelos (dados não mostrados). Foram testados modelos com diferentes graus de especificidade, em nível de famílias, gênero e espécie de vírus.

A Tabela 24 apresenta os resultados obtidos para o metagenoma SRR7617262, uma amostra derivada de um pool de 200 cepas de vírus Chikungunya (CHIKV). Como pode ser visto, leituras positivas foram detectadas por modelos conservados para a família Togaviridae, para o gênero Alphavirus e, finalmente, para o CHIKV. O número detectado de leituras para cada modelo varia conforme a cobertura presente no metagenoma, podendo existir regiões mais representadas que outras. Resultados semelhantes foram observados para modelos específicos outras espécies de vírus, bem como do gênero Rubivirus (dados não mostrados). 
Tabela 24 - Resultados gerados pelo programa HMM-prospector para uma prospecção com HMMs de perfil da família Togaviridae contra o metagenoma SRR7617262.

\section{Modelos positivos}

\section{Número de leituras detectados pelo modelo}

Alphavirus_Nonstructural_10_1749-1808 9

Alphavirus_Nonstructural_11_1691-1719

Alphavirus_Nonstructural_14_1426-1471

Alphavirus_Nonstructural_15_1372-1407

Alphavirus_Nonstructural_16 1347-1368

5215

5161

Alphavirus_Nonstructural_17_1263-1292 1239

Alphavirus_Nonstructural_18_1223-1259 1915

Alphavirus_Nonstructural_19_1136-1195 1390

Alphavirus_Nonstructural_20_1064-1123 60

Alphavirus_Nonstructural_21_1030-1055 57

Alphavirus_Nonstructural_22_956-1003 15

Alphavirus_Nonstructural_23_889-948 40

Alphavirus_Nonstructural_24_855-875 29

Alphavirus_Nonstructural_25_821-851 21

Alphavirus_Nonstructural_26_763-816 11

Alphavirus_Nonstructural_27_686-745 16

Alphavirus_Nonstructural_28_629-661 26

Alphavirus_Nonstructural_29_551-581 13

Alphavirus_Nonstructural_30_487-546 9

Alphavirus_Nonstructural_31_367-426 142

Alphavirus_Nonstructural_32_338-362 15

Alphavirus_Nonstructural_33_283-331 30

Alphavirus_Nonstructural_34_262-281 46

Alphavirus_Nonstructural_35_224-259 79

Alphavirus_Nonstructural_36_198-217 94

Alphavirus_Nonstructural_37_163-183 550

Alphavirus_Nonstructural_38_128-156 1522

Alphavirus_Nonstructural_39_102-122 1616

Alphavirus_Nonstructural_40_36-83 1262

Alphavirus_Nonstructural_9_1817-1876 4

Alphavirus_Structural_10_848-875 89

Alphavirus_Structural_11_788-847 4

Alphavirus_Structural_12_748-771 83

Alphavirus_Structural_13_692-712 70

Alphavirus_Structural_14_647-683 45

Alphavirus_Structural_15_526-560 34

Alphavirus_Structural_16_502-524 25

Alphavirus_Structural_17_438-471 48

Alphavirus_Structural_18_341-382 12

Alphavirus_Structural_19_277-336 9

Alphavirus_Structural_1_1367-1426 198

Alphavirus_Structural_20_231-252 32

Alphavirus_Structural_21_1441-1500 1005

Alphavirus_Structural_2_1276-1297 89

Alphavirus_Structural_3_1226-1272 196

Alphavirus_Structural_4_1202-1222 696

Alphavirus_Structural_5_1174-1200 1311

Alphavirus_Structural_6_1120-1146 4671

Alphavirus_Structural_7_1055-1087 3815

Alphavirus_Structural_8_971-1007 750

Chikungunya-virus_Nonstructural_10_93-123 1357

Chikungunya-virus_Nonstructural_11_2803-2830 652

Chikungunya-virus_Nonstructural_1_2303-2355 350

Chikungunya-virus_Nonstructural_4_1339-1359 74

Chikungunya-virus_Nonstructural_7_1116-1168 1637

Chikungunya-virus_Nonstructural_8_1047-1067 1630

Chikungunya-virus_Nonstructural_9_1007-1033 339

Chikungunya_Onyong_Structural_10_544-602 59

Chikungunya_Onyong_Structural_11_603-632 7

Chikungunya_Onyong_Structural_12_633-691 85

Chikungunya_Onyong_Structural_13_692-713 716 


\begin{tabular}{lc}
\hline Chikungunya_Onyong_Structural_15_773-808 & 2048 \\
Chikungunya_Onyong_Structural_24_1223-1248 & 2705 \\
Chikungunya_Onyong_Structural_2_59-117 & 15 \\
Chikungunya_Onyong_Structural_5_305-339 & 27 \\
Togaviridae_Nonstructural_10_385-444 & 148 \\
Togaviridae_Nonstructural_18_855-875 & 33 \\
Togaviridae_Nonstructural_19_886-945 & 31 \\
Togaviridae_Nonstructural_21_1030-1055 & 57 \\
Togaviridae_Nonstructural_28_1547-1598 & 47 \\
Togaviridae_Nonstructural_2_102-122 & 1622 \\
Togaviridae_Nonstructural_33_2365-2394 & 1937 \\
Togaviridae_Nonstructural__163-183 & 553 \\
Togaviridae_Nonstructural_5_198-217 & 94 \\
Togaviridae_Nonstructural_6_224-259 & 76 \\
Togaviridae_Nonstructural_9_338-362 & 15 \\
\hline
\end{tabular}

*A nomenclatura de cada modelo inclui o nome taxonômico, proteína de origem, número do modelo e coordenadas do bloco de alinhamento utilizado para sua construção. 


\section{Conclusões}

O presente trabalho permitiu estabelecer e validar metodologias de construção de HMMs de perfil com a ferramenta TABAJARA utilizando como modelos de estudo alguns grupos virais: Bunyavirales, Spounavirinae e Togaviridae. A partir dos resultados obtidos ao longo do trabalho, foi possível otimizar os protocolos, bem como aprimorar estratégias de validação dos modelos. As contribuições alcançadas foram:

- Padronização de protocolos de construção de HMMs de perfil para sequências virais;

- Estabelecimento de protocolos de validação de HMMs de perfil em dados de sequenciamento metagenômico;

- Criação de HMMs de perfil com diferentes níveis de especificidade:

- Modelos específicos para cada família e gênero da ordem Bunyavirales;

- Modelos conservados para a subfamília Spounavirinae e específicos para cada um dos gêneros da subfamília;

- Modelos conservados para a família Togaviridae e específicos para cada um dos gêneros da família;

- Modelos específicos para diferentes grupos de espécies do gênero Alphavirus, incluindo um clado de amostras de vírus Chikungunya;

- Aplicação de HMMs de perfil para a identificação taxonômica de vírus não classificados da família Myoviridae e reclassificação de gêneros órfãos.

\subsection{Perspectivas futuras do trabalho}

A partir dos resultados obtidos neste trabalho, abrem-se a seguintes perspectivas de continuidade:

- Utilização da metodologia desenvolvida para a prospecção de vírus conhecidos e emergentes, visando incrementar o conhecimento da diversidade viral:

○ Aplicação dos HMMs de perfil obtidos para a prospecção de vírus em amostras metagenômicas;

○ Utilização do programa GenSeed-HMM (Alves et al., 2016) para a reconstrução de sequências virais por montagem progressiva nas amostras metagenômicas positivas;

- Estender a metodologia de construção de HMMs de perfil com o programa TABAJARA para outros grupos taxonômicos virais. 
- Utilizar HMMs de perfil taxonomicamente definidos como ferramenta para a identificação de vírus não ainda classificados. 


\section{Referências Bibliográficas}

Ackermann, H. W. (2003). Bacteriophage observations and evolution. Research in Microbiology, 154(4), 245-251.

Adami, C. (2004). Information theory in molecular biology. Physics of Life Reviews, 1(1), 3 22.

Albornoz, A., Hoffmann, A. B., Lozach, P. Y., \& Tischler, N. D. (2016). Early Bunyavirushost cell interactions. Viruses, 8(5), 143.

Alemayehu, D., Ross, R. P., O'Sullivan, O., Coffey, A., Stanton, C., Fitzgerald, G. F., \& McAuliffe, O. (2009). Genome of a virulent bacteriophage Lb338-1 that lyses the probiotic Lactobacillus paracasei cheese strain. Gene, 448(1), 29-39.

Alves, J. M., de Oliveira, A. L., Sandberg, T. O., Moreno-Gallego, J. L., de Toledo, M. A., de Moura, E. M., Oliveira, S. L., Durham, M. A., Mehnert, U. D., Zanotto, A. M. P., Gruber, A., \& Reyes, A. (2016). GenSeed-HMM: a tool for progressive assembly using profile HMMs as seeds and its application in Alpavirinae viral discovery from metagenomic data. Frontiers in Microbiology, 7, 269.

Asare, P. T., Jeong, T. Y., Ryu, S., Klumpp, J., Loessner, M. J., Merrill, B. D., \& Kim, K. P. (2015). Putative type 1 thymidylate synthase and dihydrofolate reductase as signature genes of a novel bastille-like group of phages in the subfamily Spounavirinae. BMC Genomics, 16(1), 582.

Ballinger, M. J., Medeiros, A. S., Qin, J., \& Taylor, D. J. (2017). Unexpected differences in the population genetics of phasmavirids (Bunyavirales) from subarctic ponds. Virus Evolution, $3(1)$, vex015.

Baltimore. D. (1971). Expression of Animal Virus Genomes. Bacteriological Reviews, 35(3), 235-241.

Barylski, J., Enault, F., Dutilh, E. B., Schuller, B. P. M., Edwards, A. R., Gillis, A., Klumpp, J., Knezevic, P., Krupovic, M., Kuhn, H. J., Lavigne, R., Oksanen, M. H., Sullivan, B. M., Wittmann, J., Tolstoy, I., Brister, J. R., Kropinski, M. A., \& Adriaenssens, M. E. (2018). 
Analysis of Spounaviruses as a Case Study for the Overdue Reclassification of Tailed Bacteriophages. bioRxiv 220434; doi: https://doi.org/10.1101/220434.

Barylski, J., Nowicki, G., \& Goździcka-Józefiak, A. (2014). The discovery of phiAGATE, a novel phage infecting Bacillus pumilus, leads to new insights into the phylogeny of the subfamily Spounavirinae. PLOS ONE, 9(1), e86632.

Bateman, A., Coin, L., Durbin, R., Finn, R. D., Hollich, V., Griffiths-Jones, S., Khanna, M. M., Moxon, S., Sonnhammer, L. L. E., Studholme, D. J., Yeats, C., \& Eddy, R. S. (2004). The Pfam protein families database. Nucleic Acids Research, 32(suppl_1), D138-D141.

Beijerinck, M. W. (1898). Concerning a contagium vivum fluidum as cause of the spot disease of tobacco leaves. Phytopathology Classics, 7(1), 33-52.

Bergh, Ø., ВØrsheim, K. Y., Bratbak, G., \& Heldal, M. (1989). High abundance of viruses found in aquatic environments. Nature, 340(6233), 467.

Brenner, S. E., Chothia, C., \& Hubbard, T. J. (1998). Assessing sequence comparison methods with reliable structurally identified distant evolutionary relationships. Proceedings of the National Academy of Sciences USA, 95(11), 6073-6078.

Brister, J. R., Ako-Adjei, D., Bao, Y., \& Blinkova, O. (2014). NCBI viral genomes resource. Nucleic Acids Research, 43(D1), D571-D577.

Capra, J. A., \& Singh, M. (2007). Predicting functionally important residues from sequence conservation. Bioinformatics, 23(15), 1875-1882.

Carlton, R. M., Noordman, W. H., Biswas, B., De Meester, E. D., \& Loessner, M. J. (2005). Bacteriophage P100 for control of Listeria monocytogenes in foods: genome sequence, bioinformatic analyses, oral toxicity study, and application. Regulatory Toxicology and Pharmacology, 43(3), 301-312.

Casseb, A. R., Silva, S. P., Casseb, L. M. N., Chiang, J. O., Martins, L. C., \& Vasconcelos, P. F. C. (2015). Prevalência de anticorpos contra arbovírus da família Bunyaviridae em búfalos de água. Ciência Animal Brasileira, 16(3), 428-436. 
Černý, J., Bolfíková, B. Č., Paolo, M. D. A., Grubhoffer, L., \& Růžek, D. (2015). A deep phylogeny of viral and cellular right-hand polymerases. Infection, Genetics and Evolution, $36,275-286$.

Chen, R., Mukhopadhyay, S., Merits, A., Bolling, B., Nasar, F., Coffey, L. L., Powers, A., \& Weaver, S. C. (2018). ICTV Virus Taxonomy Profile: Togaviridae. Journal of General Virology, 99, 761-762.

Cho, K., Eckel, C. S., Walgenbach, J. F., \& Kennedy, G. G. (1995). Comparison of colored sticky traps for monitoring thrips populations (Thysanoptera: Thripidae) in staked tomato fields. Journal of Entomological Science, 30(2), 176-190.

Cline, T. D., Beck, D., \& Bianchini, E. (2017). Influenza virus replication in macrophages: balancing protection and pathogenesis. The Journal of General Virology, 98(10), 2401.

Cui, Y. C., Wu, Q., Teh, S. W., Peli, A., Bu, G., Qiu, Y. S., Benelli, G., \& Kumar, S. S. (2018). Bone breaking infections-A focus on bacterial and mosquito-borne viral infections. Microbial Pathogenesis, 122(1), 130-136.

Drake, J. W. (1993). Rates of spontaneous mutation among RNA viruses. Proceedings of the National Academy of Sciences USA, 90(9), 4171-4175.

Eddy, S. R. (1998). Profile hidden Markov models. Bioinformatics, 14(9), 755-763.

Eddy, S. R. (2011). Accelerated profile HMM searches. PLoS Computational Biology, 7(10), e1002195.

Edgar, R. C. (2004). MUSCLE: multiple sequence alignment with high accuracy and high throughput. Nucleic Acids Research, 32(5), 1792-1797.

Edwards, R. A., \& Rohwer, F. (2005). Viral metagenomics. Nature Reviews Microbiology, $3(6), 504$.

Elliott, R. M. (1990). Molecular biology of the Bunyaviridae. Journal of General Virology, $71(3), 501-522$.

Elliott, R. M., Schmaljohn, C. S., \& Collett, M. S. (1991). Bunyaviridae genome structure and gene expression: In Bunyaviridae (pp. 91-141). Springer, Berlin: Heidelberg. 
Fancello, L., Raoult, D., \& Desnues, C. (2012). Computational tools for viral metagenomics and their application in clinical research. Virology, 434(2), 162-174.

Fancello, L., Trape, S., Robert, C., Boyer, M., Popgeorgiev, N., Raoult, D., \& Desnues, C. (2013). Viruses in the desert: a metagenomic survey of viral communities in four perennial ponds of the Mauritanian Sahara. The ISME journal, 7(2), 359.

Feenstra, K. A., Pirovano, W., Krab, K., \& Heringa, J. (2007). Sequence harmony: detecting functional specificity from alignments. Nucleic Acids Research, 35(Suppl.2), W495-W498.

Flint, J., Racaniello, V., Rall, G., Salka, M. A. (2015). Principles of Virology: Structure (pp 107). Washington, USA: ASM Press.

Fuhrman, J. A. (1999). Marine viruses and their biogeochemical and ecological effects. Nature, 399(6736), 541.

Gago, S., Elena, S. F., Flores, R., \& Sanjuán, R. (2009). Extremely high mutation rate of a hammerhead viroid. Science, 323(5919), 1308-1308.

Grazziotin, A. L., Koonin, E. V., \& Kristensen, D. M. (2016). Prokaryotic virus orthologous Grupos (pVOGs): a resource for comparative genomics and protein family annotation. Nucleic Acids Research, 45(D1): D491-D498.

Guardado-Calvo, P., \& Rey, F. A. (2017). The envelope proteins of the Bunyavirales. Advances in Virus Research, 98, 83-118.

Habann, M., Leiman, P. G., Vandersteegen, K., Van den Bossche, A., Lavigne, R., Shneider, M. M., Bielmann, R., Eugster, M. R., Loessner, M. J., \& Klumpp, J. (2014). Listeria phage A511, a model for the contractile tail machineries of SPO1-related bacteriophages. Molecular Microbiology, 92(1), 84-99.

Haft, D. H., Selengut, J. D., \& White, O. (2003). The TIGRFAMs database of protein families. Nucleic Acids Research, 31(1), 371-373.

Handelsman, J., Rondon, M. R., Brady, S. F., Clardy, J., \& Goodman, R. M. (1998). Molecular biological access to the chemistry of unknown soil microbes: a new frontier for natural products. Chemistry \& Biology, 5(10), R245-R249. 
Helenius, A. (1995). Alphavirus and Flavivirus glycoproteins: structures and functions. Cell, 81(5), 651-653.

Hobson-Peters, J., Warrilow, D., McLean, B. J., Watterson, D., Colmant, A. M., van den Hurk, A. F., Hall-Mendelin, S., Hastie, M. L., Gorman, J. J., Harrison, J. J., Prow, N. A., \& Barnard, R. T. (2016). Discovery and characterisation of a new insect-specific Bunyavirus from Culex mosquitoes captured in northern Australia. Virology, 489(1), 269-281.

Holland, J., Spindler, K., Horodyski, F., Grabau, E., Nichol, S., \& VandePol, S. (1982). Rapid evolution of RNA genomes. Science, 215(4540), 1577-1585.

Hontz, R. D., Guevara, C., Halsey, E. S., Silvas, J., Santiago, F. W., Widen, S. G., Wood, G. T., Casanova, W., Vasilakis, N., Watts, M. D., Kochel, T. J., Ebihara, H., \& Aguilar, V. P (2015). Itaya virus, a novel Orthobunyavirus associated with human febrile illness, Peru. Emerging Infectious Diseases, 21(5), 781.

Huerta-Cepas, J., Szklarczyk, D., Forslund, K., Cook, H., Heller, D., Walter, M. C., Rattei, T., Mende, R. D., Sunagawa, S., Kuhn, M., Jensen, J. L., Mering, V. C., \& Bork, P. (2015). eggNOG 4.5: a hierarchical orthology framework with improved functional annotations for eukaryotic, prokaryotic and viral sequences. Nucleic Acids Research, 44(D1), D286-D293.

Huson, D. H., \& Scornavacca, C. (2012). Dendroscope 3: an interactive tool for rooted phylogenetic trees and networks. Systematic Biology, 61(6), 1061-1067.

Ibrahim, B., Arkhipova, K., Andeweg, A. C., Posada-Céspedes, S., Enault, F., Gruber, A., Koonin, E. V., Kupczok, A., Lemey, P., McHardy, A. C., McMahon, D. P., Pickett, B. E., Robertson, D. L., Scheuermann, R. H., Zhernakova, A., Zwart, M. P., Schönhuth, A., Dutilh, B. E., \& Marz, M. (2018). Bioinformatics Meets Virology: The European Virus Bioinformatics Center's Second Annual Meeting. Viruses, 10(5), 256.

Johnson, M., Zaretskaya, I., Raytselis, Y., Merezhuk, Y., McGinnis, S., \& Madden, T. L. (2008). NCBI BLAST: a better web interface. Nucleic Acids Research, 36(Suppl.2), W5W9.

Kallinen, A. K., Lindberg, I. L., Tugume, A. K., \& Valkonen, J. P. (2009). Detection, distribution, and genetic variability of European Mountain Ash Ringspot Associated Virus. Phytopathology, 99(4), 344-352. 
Khalifa, L., Brosh, Y., Gelman, D., Coppenhagen-Glazer, S., Beyth, S., Poradosu-Cohen, R., Que, Y., Beyth, N., \& Hazan, R. (2015). Targeting Enterococcus faecalis biofilms with phage therapy. Applied and Environmental Microbiology, 81(8), 2696-2705.

Klumpp, J., Lavigne, R., Loessner, M. J., \& Ackermann, H. W. (2010). The SPO1-related bacteriophages. Archives of Virology, 155(10), 1547-1561.

Kwan, T., Liu, J., DuBow, M., Gros, P., \& Pelletier, J. (2005). The complete genomes and proteomes of 27 Staphylococcus aureus bacteriophages. Proceedings of the National Academy of Sciences of the United States of America, 102(14), 5174-5179.

Kwiatek, M., Parasion, S., Mizak, L., Gryko, R., Bartoszcze, M., \& Kocik, J. (2012). Characterization of a bacteriophage, isolated from a cow with mastitis, that is lytic against Staphylococcus aureus strains. Archives of Virology, 157(2), 225-234.

Lavigne, R., Darius, P., Summer, E. J., Seto, D., Mahadevan, P., Nilsson, A. S., Ackermann, H. W., \& Kropinski, A. M. (2009). Classification of Myoviridae bacteriophages using protein sequence similarity. BMC Microbiology, 9, 224.

Luque, D., Mata, C., Suzuki, N., Ghabrial, S., \& Castón, J. (2018). Capsid Structure of dsRNA Fungal Viruses. Viruses, 10(9), 481.

Maes, P., Alkhovsky, S. V., Bào, Y., Beer, M., Birkhead, M., Briese, T., Buchmeier, J. M., Calisher, H. C., Charrel, N. R., Choi, R. I., et al. (2018). Taxonomy of the family Arenaviridae and the order Bunyavirales: update 2018. Archives of Virology, 163(8), 22952310.

Martin, B., Hoenen, T., Canard, B., \& Decroly, E. (2016). Filovirus proteins for antiviral drug discovery: A structure/function analysis of surface glycoproteins and virus entry. Antiviral Research, 135, 1-14.

Medeiros, R. B., Resende, R. O., Carvalho, R. C. P., Dianese, E. C., Costa, C. L., \& Sgro, J-Y. (2015). Virologia Vegetal: conceitos, fundamentos, classificação e controle (pp 47). Brasilia, BRA: Editora UnB.

Mokili, J. L., Rohwer, F., \& Dutilh, B. E. (2012). Metagenomics and future perspectives in virus discovery. Current Opinion in Virology, 2(1), 63-77. 
Navarro, B., Minutolo, M., de Stradis, A., Palmisano, F., Alioto, D., \& Di Serio, F. (2018). The first phlebo-like virus infecting plants: a case study on the adaptation of negative-stranded RNA viruses to new hosts. Molecular Plant Pathology, 19(5), 1075-1089.

Naveca, F. G., Nascimento, V. A., Souza, V. C., \& de Figueiredo, R. (2018). Human Orthobunyavirus Infections, Tefé, Amazonas, Brazil. PLOS Currents, 10, ecurrents.outbreaks.7d65e5eb6ef75664da68905c5582f7f7.

O'flaherty, S., Ross, R. P., Meaney, W., Fitzgerald, G. F., Elbreki, M. F., \& Coffey, A. (2005). Potential of the polyvalent anti-Staphylococcus bacteriophage $\mathrm{K}$ for control of antibioticresistant Staphylococci from hospitals. Applied and Environmental Microbiology, 71(4), 1836-1842.

Oliveira, R. C., Gentile, R., Guterres, A., Fernandes, J., Teixeira, B. R., Vaz, V., Valdez, V. P., Vicente, L. H., da Costa-Neto, S. F., Bonvicino, C., D’Andrea, P. S., \& Lemos E. R. (2014). Ecological study of Hantavirus infection in wild rodents in an endemic area in Brazil. Acta Tropica, 131(1), 1-10.

Park, J., Karplus, K., Barrett, C., Hughey, R., Haussler, D., Hubbard, T., \& Chothia, C. (1998). Sequence comparisons using multiple sequences detect three times as many remote homologues as pairwise methods1. Journal of Molecular Biology, 284(4), 1201-1210.

Parkman, P. D., Buescher, E. L., \& Artenstein, M. S. (1962). Recovery of Rubella virus from army recruits. Proceedings of the Society for Experimental Biology and Medicine, 111(1), 225-230.

Pauvolid-Corrêa, A., Campos, Z., Soares, R., Nogueira, R. M. R., \& Komar, N. (2017). Neutralizing antibodies for Orthobunyaviruses in Pantanal, Brazil. PLoS Neglected Tropical Diseases, 11(11), e0006014.

Price, M. N., Dehal, P. S., Arkin, A. P. (2010). FastTree 2--approximately maximum-likelihood trees for large alignments. PLOS ONE, 5(3), e9490.

Reyes, A., Alves, J. M. P., Durham, A., \& Gruber, A. (2017). Use of profile hidden Markov models in viral discovery: Current insights. Advances in Genomics and Genetics, 7, 29-45.

Rohwer, F., \& Edwards, R. (2002). The Phage Proteomic Tree: a genome-based taxonomy for phage. Journal of Bacteriology, 184(16), 4529-4535. 
Sakurai, Y. (2015). Ebola virus host cell entry. Uirusu, 65(1), 71-82.

Sanjuán, R., \& Domingo-Calap, P. (2016). Mechanisms of viral mutation. Cellular and Molecular Life Sciences, 73(23), 4433-4448.

Sanjuán, R., Nebot, M. R., Chirico, N., Mansky, L. M., Belshaw, R. (2010). Viral mutation rates. Journal of Virology, 84(19), 9733-9748.

Segobola, J., Adriaenssens, E., Tsekoa, T., Rashamuse, K., \& Cowan, D. (2018). Exploring viral diversity in a unique South African soil habitat. Scientific Reports, 8(1), 111.

Shannon, C. E. (2001). A mathematical theory of communication. ACM SIGMOBILE Mobile Computing and Communications Review, 5(1), 3-55.

Sibhat, B., Ayelet, G., Gebremedhin, E. Z., Skjerve, E., \& Asmare, K. (2018). Seroprevalence of Schmallenberg virus in dairy cattle in Ethiopia. Acta Tropica, 178(1), 61-67.

Skewes-Cox, P., Sharpton, T. J., Pollard, K. S., \& DeRisi, J. L. (2014). Profile hidden Markov models for the detection of viruses within metagenomic sequence data. PLOS ONE, 9, e10506.

Stewart, C. R., Casjens, S. R., Cresawn, S. G., Houtz, J. M., Smith, A. L., Ford, M. E., Peebles, C. L., Hatfull, G. F., Hendrix, R. W., Huang, W. M., \& Pedulla, M. L. (2009). The genome of Bacillus subtilis bacteriophage SPO1. Journal of Molecular Biology, 388(1), 48-70.

Strauss, H. J., \& Strauss, G. E. (1994). The Alphaviruses: Gene Expression, Replication, and Evolution. Microbiological Reviews, 58(3), 491-562.

Tang, H., Hammack, C., Ogden, S. C., Wen, Z., Qian, X., Li, Y., Yao, B., Shin, J., Zhang, F. Lee, M. E., Christian, M. K., Didler, A. R., Jin, P., Soung, H., \& Ming, G-L. (2016). Zika virus infects human cortical neural progenitors and attenuates their growth. Cell Stem Cell, $18(5), 587-590$.

Tavares, P. (2018). The Bacteriophage Head-to-Tail Interface: In Virus Protein and Nucleoprotein Complexes (pp. 305-328). Singapore: Springer.

Thomas, P. D., Campbell, M. J., Kejariwal, A., Mi, H., Karlak, B., Daverman, R., Diemer, K., Muruganujan, A., \& Narechania, A. (2003). PANTHER: a library of protein families and subfamilies indexed by function. Genome Research, 13(9), 2129-2141. 
Tigertt, W. D., \& Downs, W. G. (1962). Studies on the virus of Venezuelan equine encephalomyelitis in Trinidad, WI. The American Journal of Tropical Medicine and Hygiene, 11(6), 822-834.

Uchiyama, J., Maeda, Y., Takemura, I., Gamoh, K., Matsuzaki, S., \& Daibata, M. (2012). Analysis of deoxynucleosides in bacteriophages $\phi \mathrm{EF} 24 \mathrm{C}$ and $\mathrm{K}$ and the frequency of a specific restriction site in the genomes of members of the bacteriophage subfamily Spounavirinae. Archives of Virology, 157(8), 1587-1592.

Uchiyama, J., Rashel, M., Takemura, I., Wakiguchi, H., \& Matsuzaki, S. (2008). In silico and in vivo evaluation of bacteriophage $\varphi \mathrm{EF} 24 \mathrm{C}$, a candidate for treatment of Enterococcus faecalis infections. Applied and Environmental Microbiology, 74(13), 4149-4163.

Urbanowicz, R. A., McClure, C. P., Sakuntabhai, A., Sall, A. A., Kobinger, G., Müller, M. A., Holmes, C. E., Rey, A. F., Simon-Loriere, E., \& Ball, J. K. (2016). Human adaptation of Ebola virus during the West African outbreak. Cell, 167(4), 1079-1087.

Vratnica, Z., Busani, L., Zeković, Ž., Rakočević, B., Medenica, S., Urciuoli, R., Rezza. G., \& Mugoša, B. (2017). Haemorrhagic fever with renal syndrome in Montenegro, 2004-14. The European Journal of Public Health, 27(6), 1108-1110.

Wattam, A. R., Davis, J. J., Assaf, R., Boisvert, S., Brettin, T., Bun, C., Conrad, N., Dietrich, E. M., Disz, T., Gabbard, J. L., Gerdes, S., Henry, C. S., Kenyon, R. W., Machi, D., Mao, C., Nordberg, E. K., Olsen, G. J., Murphy-Olson, D. E., Olson, R., Overbeek, R., Parrello, B., Pusch, G. D., Shukla, M., Vonstein, V., Warren, A., Xia, F., Yoo, H., Stevens, R. L. (2016). Improvements to PATRIC, the all-bacterial bioinformatics database and analysis resource center. Nucleic Acids Research, 45(D1), D535-D542.

Weller, T. H., \& Neva, F. A. (1962). Propagation in Tissue Culture of Cytopathic Agents from Patients with Rubella-Like Illness. Proceedings of the Society for Experimental Biology and Medicine, 111(1), 215-225.

Willms, I. M., Hoppert, M., \& Hertel, R. (2017). Characterization of Bacillus subtilis Viruses vB_BsuM-Goe2 and vB_BsuM-Goe3. Viruses, 9(6), 146. 
Yosef, I., Edgar, R., Levy, A., Amitai, G., Sorek, R., Munitz, A., \& Qimron, U. (2016). Natural selection underlies apparent stress-induced mutagenesis in a bacteriophage infection model. Nature Microbiology, 1(6), 16047.

Zanotto, P. D., Gibbs, M. J., Gould, E. A., \& Holmes, E. C. (1996). A reevaluation of the higher taxonomy of viruses based on RNA polymerases. Journal of Virology, 70(9), 6083-6096. 